\title{
Expedition 316 methods ${ }^{1}$
}

\author{
Expedition 316 Scientists $^{2}$
}

\section{Chapter contents}

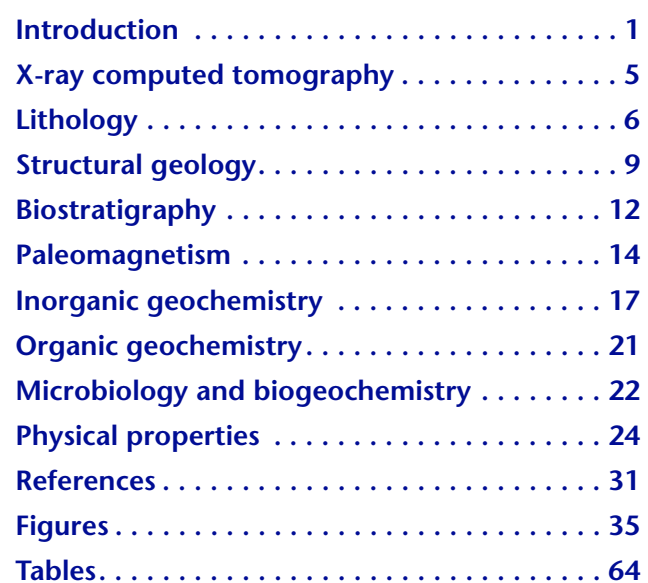

'Expedition 316 Scientists, 2009. Expedition 316 methods. In Kinoshita, M., Tobin, H., Ashi, J., Kimura, G., Lallemant, S., Screaton, E.J., Curewitz, D., Masago, H., Moe, K.T., and the Expedition 314/315/316 Scientists, Proc. IODP, 314/315/316: Washington, DC (Integrated Ocean Drilling Program Management International, Inc.). doi:10.2204/iodp.proc.314315316.132.2009 'Expedition 314/315/316 Scientists' addresses.

\section{Introduction}

This chapter documents the methods used for shipboard scientific analyses, including sample collection, preparation, and preservation for either shipboard or shore-based analysis. This information can be used to understand the means by which we arrived at preliminary conclusions and interpretations and to provide information for those interested in ancillary analyses, shore-based sampling, or integrative investigations.

This chapter also covers coring techniques, core handling, and the numbering of sites, holes, cores, sections, and samples. In most cases, this information mirrors the details described in previous volumes of the Proceedings of the Integrated Ocean Drilling Program. However, because of the relationship between this expedition and the other expeditions that comprise the Nankai Trough Seismogenic Zone Experiment (NanTroSEIZE) and the large number and volume of sample requests, there are significant differences that will be explained below.

\section{Site locations}

Integrated Ocean Drilling Program (IODP) Expedition 316 site locations were selected based on precruise surveys. Onboard Global Positioning System (GPS) satellite navigation was used to position the vessel using dynamic positioning, and acoustic beacons deployed on the seafloor provided additional means of acquiring and keeping vessel position during operations. When the remotely operated vehicle (ROV) was deployed, a precise fix on the location of the borehole was obtained upon spud-in. When operations took place without ROV support, hole position was determined based on the vessel GPS fix.

\section{Drilling operations}

Four coring systems were employed during Expedition 316:

1. Hydraulic piston coring system (HPCS) equivalent to the advanced piston coring (APC) system employed on the R/V JOIDES Resolution,

2. Extended shoe coring system (ESCS) equivalent to the extended core barrel (XCB) system employed on the JOIDES Resolution, 
3. Rotary core barrel (RCB), and

4. ESCS "punch" prototype.

The ESCS punch coring method was tested for the first time during Expedition 316, following the determination that all scientific objectives achievable during the allotted time had been met (after nominal total depth had been reached in Hole C0008C). The ESCS punch system was designed to extend the range of nonrotational coring ahead of the bit into formations that are too consolidated for HPCS coring yet not competent to support rotary coring (either ESCS or RCB). The system utilizes a combination of an ESCS lower outer barrel assembly, an RCB upper outer barrel assembly, an HPCS lower core barrel and cutting shoe, and an ESCS upper core barrel. The HPCS lower core barrel and cutting shoe extends beyond the coring bit, similar to the configuration of the standard ESCS system; however, this cutting shoe does not rotate and is latched in place within the bottom-hole assembly (BHA). The system takes advantage of the downward pressure exerted by the weight of the drill string, controlled via the drawworks winch, to force the extended cutting shoe into the formation ahead of the coring bit. Cores are collected and retained using a core catcher assembly similar to that employed on standard HPCS piston coring systems. Three coring runs with this prototype system proved extremely promising, delivering high-quality cores at high rates of recovery in material that often proves problematic to core with the HPCS, RCB, or standard ESCS systems. Further testing and development of this system are ongoing and will be the subject of upcoming Center for Deep Earth Exploration (CDEX) technical notes.

Drilled intervals are initially referred to in drillers depth below rig floor (DRF), which is measured from the kelly bushing on the rig floor to the bottom of the drill pipe, and later converted to core depth below seafloor (CSF). When sediments of substantial thickness cover the seafloor, the DRF depth of the seafloor is determined using either the ROV as an absolute reference or a mudline core combined with the length of the drill string at the time of shooting the first core. The mudline core is taken by tagging the seafloor with the drill bit, lifting the bit to a point $<9.5 \mathrm{~m}$ off bottom, and shooting a partial HPCS core. Water depth is either directly measured (using the ROV) or calculated by subtracting the distance from the rig floor to sea level from the mudline measurement (DRF). CSF depths of core tops are determined by subtracting seafloor depth (DRF) from core top depth (DRF). The resulting core top data (CSF) are the ultimate reference for any further depth calculation procedures.

\section{Drilling-induced core deformation}

X-ray computed tomography (CT) imagery and direct inspection of split cores often reveal significant evidence for disturbance of recovered materials. HPCS-related disturbance includes the concavedownward appearance of originally horizontal bedding and liquefaction features related to differential compaction of layers with different competency and pore fluid content as well as the suction-induced flow of significant amounts of exotic material into the bottom of incomplete HPCS penetrations. ESCS/ RCB-related disturbance includes the rotation and "spiraling" of sections of cores, "biscuiting" of small sections of core and injection of either drilling mud or finely ground material produced at the drill bit into spaces between individual biscuits, or brecciation or grinding of material before collection into the core liner/core barrel. Core deformation may also result from depressurization, expansion, and thermal equilibration of the core as it travels up the drill string, during handling on deck, and during core cutting and splitting. Where possible, such core disturbance was noted in core descriptions.

\section{Numbering of sites, holes, cores, sections, and samples}

Sites drilled by the D/V Chikyu are numbered consecutively from the first site with a prefix "C." A site refers to one or more holes drilled while the ship is positioned within $300 \mathrm{~m}$ of the first hole. The first hole drilled at a given site is assigned the site number modified by the suffix "A," the second hole takes the site number and suffix " $\mathrm{B}$," and so forth. These suffixes are assigned regardless of recovery, as long as penetration takes place. During Expedition 316, we drilled at Sites C0004 (proposed Site NT2-01I), C0006 (proposed Site NT1-03B), C0007 (proposed Site NT1-03A), and C0008 (proposed Site NT2-10A). During Expedition 316, the Chikyu occupied Holes C0004C and C0004D; Holes C0006C, C0006D, C0006E, and C0006F; Holes C0007A, C0007B, C0007C, and C0007D; and Holes C0008A, C0008B, and $\mathrm{C0008 \textrm {C } \text { . }}$

Cored intervals are calculated based on an initial $9.5 \mathrm{~m}$ length, which is the standard core barrel length for each coring system. Partial penetration of the HPCS core barrel is generally detectable during coring by measurement of the pressure drop in the hydraulic system that powers the piston core. Partial pressure drop and gradual release of pressure is used to calculate the estimated penetration depth in these cases. In addition, we specified the collection of $4.5 \mathrm{~m}$ long coring intervals when using the RCB in areas of extreme interest thought to contain fragile 
or fractured rocks in fault zones. Expansion of cores in the upper sections (and sucked-in material) and gaps related to unrecovered material result in recovery percentages greater or less than $100 \%$, respectively. Depth intervals are assigned starting from the depth below seafloor at which coring started (IODP coring depth scale calculated using Method A [CSF]). Short cores (incomplete recovery) are all assumed to start from that initial depth by convention. Core expansion is corrected during final processing of core measurements by subtracting void spaces, subtracting exotic material, and accounting for expansion (IODP coring depth scale calculated using Method B [CSF-B]).

A recovered core is typically divided into $1.5 \mathrm{~m}$ long sections that are numbered serially from 1 beginning at the top. During this expedition and IODP Expedition 315, whole-round core samples removed for collection of time-sensitive interstitial water sampling were often assigned their own section number in order to allow for rapid X-ray CT scanning of timesensitive samples. Material recovered from the core catcher was assigned to a separate section, labeled core catcher (CC), and placed at the bottom of the lowermost section of the recovered core.

A full identification number for a sample consists of the following information: expedition, site, hole, core number, core type, section number, and top to bottom interval in centimeters measured from the top of the section. For example, a sample identification of "316-C0004C-2H-5, 80-85 cm," represents a sample removed from the interval between 80 and $85 \mathrm{~cm}$ below the top of Section 5 of the second HPCS core from Hole C0004C, during Expedition 316 (Fig. F1). All IODP core identifiers indicate core type. The following abbreviations are used:

$$
\begin{aligned}
& \mathrm{H}=\mathrm{HPCS}, \\
& \mathrm{R}=\mathrm{RCB}, \\
& \mathrm{X}=\text { ESCS, and } \\
& \mathrm{X}^{*}=\text { ESCS punch. }
\end{aligned}
$$

\section{Core handling}

The following sections describe in detail the flow of core from the drill floor through the laboratory. See Figure F2 for a step-by-step flow chart of the entire process.

\section{Core cutting area}

As soon as a core is retrieved on deck, the core catcher is delivered to the core cutting area. A sample is taken for paleontological analysis, and the remainder of the core catcher sample is packed into the core liner and curated. The whole core is delivered to the core cutting area, small $\left(5 \mathrm{~cm}^{3}\right)$ plugs of sediment are removed from the bottom of appropriate core sections for headspace gas analysis, and (primarily in shallower depths) the core is scanned with an infrared camera to identify negative temperature anomalies associated with gas hydrate or hydrate-rich intervals. Any such intervals are immediately cut out of the core, curated, and delivered to the quality assurance (QA)/quality control (QC) laboratory for processing. The recovered core length and the total length of void space are measured, and core identification, length, drilling advance, and depth information are entered into the J-CORES database. If cores contain gas in void spaces, void gas samples are collected at this time. The core is divided into sequentially numbered sections, and the sections are cut. At this time, sections chosen for interstitial water analysis by the inorganic geochemist are removed from the core, taken to the core processing deck, and scanned by $\mathrm{X}$-ray CT. Oversight by a structural geologist, sedimentologist, or geotechnical specialist acting as a "watchdog" (see below) is required before the interstitial water whole round is squeezed. If a sample is rejected by the watchdog, a new interstitial water sample is chosen. Each section is then sealed at the top (blue cap) and bottom (white cap); yellow caps indicate removed whole-round core samples (with sample code marked on the end cap). All sections are marked and labeled, data are entered into the JCORES database, and sections are moved to the core processing deck.

\section{Core processing deck}

All sections are scanned using X-ray CT, and each shift has a structural geologist or sedimentologist acting as a watchdog to oversee the collection and selection of whole-round core samples, to identify sections or intervals of special interest or unique character, and to prevent destruction of any critical samples. Whole-round core samples for microbiology and anelastic strain recovery analyses are taken immediately following X-ray CT imaging, with approval of the watchdog.

Following X-ray CT scanning and time-sensitive whole-round core sampling, core sections are allowed to equilibrate to ambient temperature (2-3 h), after which they are run through the whole-round multisensor core logger (MSCL-W). During Expedition 316, measurements of gamma ray attenuation (GRA) bulk density, $P$-wave velocity, resistivity, magnetic susceptibility, and natural gamma radiation were collected using the MSCL (Geotek Ltd., London, UK). Thermal conductivity measurements were also made on whole-round core sections for softsediment cores. 
Following thermal conductivity measurement, a second round of whole-round core sampling for shorebased geotechnical and hydrogeologic analyses is conducted under the guidance of the watchdog. Whole-round core samples for interstitial water and geotechnical analysis had associated "cluster" samples taken from the whole round before processing or storage: this group of samples was taken adjacent to each whole-round core and consists of material for X-ray diffraction (XRD), moisture and density (MAD), and carbonate analyses.

Following completion of whole-round core sampling, sections are split axially into working and archive halves. The archive half is subjected to nondestructive visual core description (VCD), digital photo image scanning, color spectroscopy, and paleomagnetic measurement, after which it is covered in plastic film, shrink-wrapped in plastic, and stored in either the cold-store refrigerator or the refrigerated containers at $4^{\circ} \mathrm{C}$. The working half is subjected to structural analysis and sampling and measurement for physical properties, including moisture and density, and is then sampled for shipboard and postcruise analyses. Following completion of sampling, these sections are also wrapped, sealed, and stored at $4^{\circ} \mathrm{C}$ in preparation for shipping to the core repository. All samples collected are labeled, packaged, stored, and shipped to their final destinations according to standard practice or special instructions.

\section{Special handling}

Expedition 316 cores collected across fault zones or inversions of paleontological age that potentially recovered well-preserved individual faults, fault rocks, and damage zones were subjected to intense X-ray CT image investigation. These cores were withheld from the standard processing procedure and were treated as follows (Fig. F3): cores were scanned by Xray $\mathrm{CT}$, critical intervals were identified, and cores were stored in the $4^{\circ} \mathrm{C}$ refrigerator. Shipboard scientists analyzed the CT imagery to identify critical sections to preserve or sample appropriately. Cores in noncritical intervals were test-split to determine the degree of disruption of fabric and structure and the best methods for description and sampling. Agreement on particular critical intervals was reached, and selected whole rounds were removed for physical properties and structural investigation. The remainder of the cores were split, described, and sampled during shift crossover to ensure that all interested parties were present for consultation and to collect material and data.

Specified samples of particular interest to the physical property specialists were sampled in whole-round form. Core sections were oriented relative to the fault zones identified (orientation of the split surface was chosen to be parallel to the direction of maximum dip of foliations or fault planes). The liners of these whole-round cores were cut along the determined orientation and lifted off the whole-round sample. The sample was then wrapped in plastic wrap and heat-sealed in two layers of plastic sleeve designed for archival core storage. This procedure was designed to stabilize the fragile material and prevent water from the rock saw from infiltrating the core material. After splitting, the samples were described and photographed and an archive and working half were designated. Both the original core orientation and the structurally determined orientation of the core relative to the liner-based reference frame were recorded. The working half was covered in plastic wrap and stored. The archive half was dried at $30^{\circ} \mathrm{C}$ for 2 days and then stabilized using several applications of epoxy resin to the half-round section. The archive half was then cut parallel to the split surface to create a true archive half for preservation and an $\sim 2 \mathrm{~cm}$ thick slab for structural, microtextural, and point chemical analyses. Splitting was carefully and slowly carried out using a standard rock saw cooled with alcohol rather than water to prevent excess hydration of clays or erosion of the fine-grained fault material. The fresh surface of the archive half and slab were then coated with a thin layer of epoxy to prevent excessive dehydration. The slab material was set aside for thin sectioning according to sample requests and description needs (both scientific and for location and contextualization of selected samples from the working half). After evaluating the above method for successful preservation, the working half of the core sample was divided lengthwise into two quarter-round pieces available for sampling for chemical, sedimentological, XRD, X-ray fluorescence (XRF), or other bulk analyses (QRND-A) and for experimental friction, consolidation, permeability, microchemistry, and potential dating experiments (QRND-E). Sample requests, potential conflicts, and other sampling arrangements were worked out by the shipboard science party and the Sample Allocation Committee in accordance with the sample requests made prior to the start of the expedition.

\section{Authorship of site chapters}

The separate sections of the site chapters and methods chapter were written by the following shipboard scientists (authors are listed in alphabetical order; no seniority is implied):

Principal results: Shipboard Science Party

X-ray computed tomography: Chester, Sakaguchi

Lithology: Fergusson, Milliken, Nicholson, Sakaguchi, Strasser 
Structural geology: Chester, Fabbri, Li, Ujiie, Yamaguchi

Biostratigraphy: Girault, Su

Paleomagnetism: Kitamura, Zhao

Inorganic geochemistry: Claesson, Solomon

Organic geochemistry: Reidinger

Microbiology and biogeochemistry: Inagaki

Physical properties (including core-log integration): Goldsby, Harris, Jiang, Knuth, Louis, Tsutsumi

\section{X-ray computed tomography}

$\mathrm{X}$-ray CT imaging provided real-time information for Expedition 316 core logging and sampling strategies. The following explanation of our methods was derived from the "cookbook" prepared by CDEX/Japan Agency for Marine-Earth Science and Technology (JAMSTEC) for onboard use (X-ray CT Scanner, version 3.00, 31 July 2007) and practical experience. The cookbook is based on GE Healthcare (2006), Mees et al. (2003), and Nakano et al. (2000).

The X-ray CT instrument on the Chikyu is a GE Yokogawa Medical Systems LightSpeed Ultra 16 capable of generating sixteen $0.625 \mathrm{~mm}$ thick slice images every $0.5 \mathrm{~s}$, the time for one revolution of the $\mathrm{X}$-ray source around the sample (see Table T1 for operating parameters). As a result of this high scanning rate, $1.5 \mathrm{~m}$ sections of core were typically imaged in $<3 \mathrm{~min}$. Data generated for each core consist of coreaxis-normal planes of X-ray attenuation values with dimensions of $512 \times 512$ pixels. Data were stored as Digital Imaging and Communication in Medicine (DICOM) formatted files.

\section{Background}

The theory behind X-ray CT has been well established through medical research and is very briefly outlined here. X-ray intensity varies as a function of $\mathrm{X}$-ray path length and the linear attenuation coefficient (LAC) of the target material as

$$
I=I_{0} \times e^{-\mu L},
$$

where

$I=$ transmitted X-ray intensity,

$I_{0}=$ initial X-ray intensity,

$\mu=$ LAC of the target material, and

$L=$ X-ray path length through the material.

LAC is a function of the chemical composition and density of the target material. The basic measure of attenuation, or radiodensity, is the CT number given in Hounsfield units (HU) and is defined as

$$
\text { CT number }=\left[\left(\mu_{t}-\mu_{w}\right) / \mu_{w}\right] \times 1000,
$$

where

$$
\begin{aligned}
& \mu_{\mathrm{t}}=\mathrm{LAC} \text { for the target material and } \\
& \mu_{\mathrm{w}}=\mathrm{LAC} \text { for water. }
\end{aligned}
$$

The distribution of attenuation values mapped to an individual slice comprises the raw data that are used for subsequent image processing. Successive twodimensional slices yield a representation of attenuation values in three-dimensional (3-D) pixels referred to as voxels. Visualizations are generally accomplished by varying the manner in which the CT number distribution is assigned to 256 shades of gray or a color pallet. Onboard analysis of CT images was made using both the Advantage Workstation (Lightspeed Ultra 16, General Electric Medical Systems) and the OsiriX 32-bit DICOM viewer (version 2.7.5) running on a G5 Macintosh (OS 10.4).

Analytical standards used during Expedition 316 were air $(\mathrm{CT}$ number $=-1000)$, water $(\mathrm{CT}$ number $=$ $0)$, and aluminum $(2467<$ CT number $<2487)$ in an acrylic core mock-up. All three standards were run once daily after air calibration, and once each week the three standards were run both before and after air calibration. For each standard analysis, the CT number was determined for a $24.85 \mathrm{~mm}^{2}$ area at fixed coordinates near the center of the cylinder.

\section{X-ray CT scan data usage}

X-ray CT scans were used routinely during Expedition 316 to

- Provide an assessment of core recovery and coreliner integrity for drilling operations,

- Determine the appropriateness of whole-round sampling,

- Identify the location of subtle features that warrant detailed study and special handling during VCD and sampling, and

- Determine 3-D geometry, cross-cutting and other spatial relations, and orientation of primary and secondary structures.

X-ray CT scans provided timely information on the integrity of the cores. Cores that experienced gas expulsion during depressurization could be readily identified, as could cores in which extensive drillinginduced disturbance had occurred (Fig. F4A). During rotary drilling, CT scans were used to determine sections of the core that underwent differential rotation and helped determine sections of the core that are contiguous with respect to orientation (Fig. F4B). The amount of core recovery and nature of drillinginduced damage may depend on drilling technique, and information from CT scans was reported to CDEX for drilling operations (Fig. F5). 
All whole-round core sections were screened to avoid destructive testing on core samples that might contain critical structural features. This also ensured minimal drilling disturbance of whole-round samples (essential for microbiology as well as physical and mechanical properties) and an assessment of whole-round homogeneity. X-ray CT scanning was done immediately after core cutting so that timesensitive whole-round samples (e.g., those for interstitial water and microbiological analyses) could be included in this screening process.

The value of X-ray CT scans to identify sedimentary and tectonic features prior to VCD was quickly recognized (Fig. F6). Three-dimensional structure orientation in the core reference frame could easily be determined from CT scan sections, whereas performing the same measurement on the cores generally requires cutting orthogonal faces. Furthermore, structures could be classified as a function of their CT contrast, which is presumably related to porosity changes or chemical alteration within shear zones. Structural and stratigraphic CT observations are incorporated into structural geology and lithologic sections.

X-ray CT scan data have multiple uses, from early assessment of cores to description and synthesis. For this reason, several hundred gigabytes of scan data $(\sim 825 \mathrm{Mb} / \mathrm{m})$ were stored on a local database at the OsiriX interpretation station. These data are archived to tape and stored on terabyte disks.

\section{Lithology Visual core descriptions}

We followed conventional Ocean Drilling Program (ODP) and IODP procedures for recording sedimentologic information on VCD forms on a section-bysection basis (Mazzullo and Graham, 1988). Core descriptions were transferred to section-scale templates using J-CORES software and then converted to core-scale depictions using Strater software. Texture (defined by the relative proportions of sand, silt, and clay) follows the classification of Shepard (1954). The classification scheme for siliciclastic lithologies follows Mazzullo et al. (1988).

The Graphic Lithology column on each VCD plots to scale all beds that are at least $2 \mathrm{~cm}$ thick. Combined graphic patterns show persistent interlayers $\leq 2 \mathrm{~cm}$ thick. It is difficult to discriminate between the dominant lithologies of silty clay and clayey silt without quantitative grain size analysis, so we grouped this entire range of textures into the category "silty clay" on all illustrations. We did not use separate patterns for more heavily indurated examples of the same lithologies (e.g., silty clay versus silty claystone) because the dividing line is arbitrary. Figure $\mathbf{F 7}$ displays graphic patterns for all lithologies encountered during Expedition 316. Also shown are symbols for internal sedimentary structures, soft-sediment deformation structures, and severity of core disturbance in both soft sediment and indurated sedimentary rock. Assessment of core disturbance by drilling and core processing is primarily based on the degree to which observed textures and fabrics depart from expected natural occurring textures and structures, and thus is a somewhat subjective determination, influenced by the experience of the observer. In tectonically deformed sediments, the distinction between natural and induced fabrics can be particularly ambiguous.

\section{Smear slides}

Smear slides are useful for identifying and reporting basic sediment attributes (texture and composition), but the results are not quantitative. We estimated the abundances of biogenic, volcaniclastic, and siliciclastic constituents with the help of a visual comparison chart (Rothwell 1989). Inherent errors are large, however, especially for fine silt and clay-size fractions, and reproducibility among different sedimentologists is poor. Smear slide analysis also tends to underestimate the amount of sand-size grains because they are difficult to incorporate evenly onto the slide. Thus, it would be misleading to report values as absolute percentages. Instead, our descriptive results are tabulated as visual percentage estimates with values grouped into the following range categories:

$$
\begin{aligned}
& \mathrm{D}=\text { dominant }(>50 \%) . \\
& \mathrm{A}=\text { abundant }(>20 \%-50 \%) . \\
& \mathrm{C}=\text { common }(>5 \%-20 \%) . \\
& \mathrm{P}=\text { present }(>1 \%-5 \%) . \\
& \mathrm{R}=\text { rare }(0.1 \%-1 \%) . \\
& \mathrm{T}=\text { trace }(<0.1 \%) .
\end{aligned}
$$

The relative abundance of major components was also validated by X-ray diffraction (see "X-ray diffraction"), and the absolute proportion of carbonate was verified by coulometric analysis (see "Organic geochemistry").

The sample location for each smear slide was entered into the J-CORES database with a sample code of SS using the Samples application. The position of each sample is shown on the VCD slide editor column of the VCD application. We tabulated data in an Excel spreadsheet because data entry into J-CORES is prohibitively time-consuming and the program will not accept ranges of values for individual compositional categories. 


\section{X-ray diffraction}

We completed routine XRD analyses of bulk powders using a Philips PANalytical CubiX PRO (PW3800) diffractometer. The principal goal was to estimate relative weight percentages of total clay minerals, quartz, plagioclase, and calcite using peak areas. A secondary goal was to determine ratios of cristobalite to quartz using peak intensity. Most of the samples were selected from intervals adjacent to whole-round samples, and most are part of sampling clusters with associated physical properties and carbonate analysis. A few additional samples were collected periodically from such unusual lithologies as carbonatecemented claystone and volcanic ash. Samples were freeze-dried, crushed with a ball mill, and mounted as random bulk powders. The instrument settings were as follows:

Generator $=40 \mathrm{kV}$ and $45 \mathrm{~mA}$.

Tube anode $=\mathrm{Cu}$.

Wavelength $=1.54184 \AA\left(\mathrm{CuK}_{\alpha}\right)$.

Step spacing $=0.01^{\circ} 2 \theta$.

Rate $=0.1$ second $/$ step.

Slits = automatic.

Measuring diameter $=10 \mathrm{~mm}$.

Scanning range $=2^{\circ} 2 \theta$ to $60^{\circ} 2 \theta$.

In order for our results to match those of ODP Leg 190 as closely as possible, the choice was made to use MacDiff 4.2.5 software (www.ccp14.ac.uk/ccp/ ccp14/ftp-mirror/krumm/Software/macintosh/ macdiff/MacDiff.html) for data processing. Each peak's upper and lower limits were adjusted following the guidelines shown in Table T2. Calculations of relative mineral abundance utilized a matrix of normalization factors derived from integrated peak areas and singular value decomposition (SVD) (Table T3). As described by Fisher and Underwood (1995), calibration of SVD factors depends on the analysis of known weight-percent mixtures of mineral standards that are appropriate matches for the natural sediments. Bulk powder mixtures for the Nankai Trough are the same as those reported by Underwood et al. (2003): quartz (Saint Peter sandstone), feldspar (Ca-rich albite), calcite (Cyprus chalk), smectite (Ca-montmorillonite), illite (Clay Mineral Society IMt-2, 2M1 polytype), and chlorite (Clay Mineral Society CCa-2). Examples of diffractograms for standard mixtures are shown in Figure F8.

Average errors (SVD-derived estimates versus true weight percent) are total clay minerals $=3.0 \%$, quartz $=1.7 \%$, plagioclase $=1.2 \%$, and calcite $=1.8 \%$ (see CDEX XRD cookbook for thorough analysis of error). In spite of its precision with standard mixtures, the SVD method is only semiquantitative and results for natural specimens should be interpreted with some caution. One of the fundamental prob- lems with any bulk powder XRD method is the difference in peak response between poorly crystalline minerals at low diffraction angles (e.g., clay minerals) and highly crystalline minerals at higher diffraction angles (e.g., quartz and plagioclase). Clay mineral content is best characterized by measuring the peak area, whereas peak intensity may be easier and more accurate to quantify quartz, feldspar, and calcite. Analyzing oriented aggregates enhances basal reflections of the clay minerals, but this step is time consuming and requires isolation of the clay-size fraction to be effective. Errors also propagate as more minerals and peaks are added to the procedure. For clay mineral assemblages, the two options are to individually measure one peak for each mineral and add the estimates together (thereby propagating the error) or to measure a single composite peak at $19.4^{\circ}$ to $20.4^{\circ} 2 \theta$. Another source of error is contamination of mineral standards by impurities such as quartz (e.g., the illite standard contains $~ 20 \%$ quartz). Peak interference is particularly problematic for estimates of cristobalite content because the (101) reflection at $22.003^{\circ} 2 \theta(\mathrm{d}$-value $=4.0397 \AA)$ is in close proximity to plagioclase peaks (e.g., albite [201] [4.032 $\AA$, $22.043^{\circ} 2 \theta$ ] and anorthite [201] [4.042 $\left.\AA, 21.988^{\circ} 2 \theta\right]$ ).

In the final assessment, calculated values of a mineral's weight percent should only be regarded as relative percentages within a four-component system of clay minerals + quartz + plagioclase + calcite. How close those estimates are to their absolute percentages within the mass of total solids will depend on the abundance of amorphous solids (e.g., biogenic opal and volcanic glass), as well as the total of all other minerals that occur in minor or trace quantities. For most natural samples, the absolute errors are probably between $5 \%$ and $10 \%$. Thus, the primary value of bulk powder XRD data should be to identify spatial and temporal trends in sediment composition and to assist with core-log integration.

\section{X-ray fluorescence}

XRF analysis of major and minor elemental composition was performed using the TATSCAN-F2 energy dispersive spectrometry (EDS)-based core scanner (Sakamoto et al., 2006). Analyses were obtained in two modes: scanning of the whole-core surface and analysis of whole-rock powders. Samples for XRF were chosen in a targeted manner to investigate specific questions concerning the spatial variation of elemental composition in particular core intervals.

The Rh X-ray source was operated at $30 \mathrm{kV}$ accelerating voltage and a current of $0.170 \mathrm{~mA}$. Data are reported as total counts on the peak and also as semiquantitative oxide weight percents. Semiquantitative analysis was performed using a $200 \mathrm{~s}$ accumu- 
lation. Oxide percentages were calculated from background-corrected integrated peak intensities using software provided by the vendor (JEOL) for the TATSCAN. Table T4 shows shipboard XRF results for the standard JSd-2 compared to the official values for this standard.

Scanning was performed at a spatial resolution of $1 \mathrm{~cm}$ and an accumulation live time of $80 \mathrm{~s}$. For interval $316-\mathrm{C} 0004 \mathrm{C}-9 \mathrm{H}-5,58-100 \mathrm{~cm}$, the scan was repeated with a $5 \mathrm{~mm}$ offset $(58.5-100.5 \mathrm{~cm})$, yielding a sampling interval of $0.5 \mathrm{~cm}$ for the entire data set.

Four applications were undertaken during Expedition 316. In the first application, XRF scanning was performed across the unconformity observed at Section 316-C0004C-9H-5 (see "Lithology" in the "Expedition 316 Site C0004" chapter). Scanning was performed twice. The first scan was made at $1 \mathrm{~cm}$ intervals from 50 to $100 \mathrm{~cm}$ (Fig. F9). The surface of the core was too rough, leaving intervals of low overall X-ray intensity. To achieve better results, the archive half of the section was smoothed in small depth increments $(1-8 \mathrm{~cm})$ using a sharp tool. The core surface was carefully cleaned with a brush between each increment and the material saved for analysis (Table T3). The unconformity slopes steeply across the core, so samples both above and below the unconformity were obtained for three intervals. The scan was repeated on the smoothed surface in $0.5 \mathrm{~cm}$ increments from 50 to $100.5 \mathrm{~cm}$ (Fig. F10), with better results. Powders from the surface-smoothing process were used for both routine XRD and XRF (as described above) (Table T5; Fig. F11). More than $1 \mathrm{~h}$ of tedious effort was required to carefully smooth the archive half without damaging the unconformity $(\sim 1.5 \mathrm{~h})$. Another hour of technician time was spent setting up the scanner and handling the data.

A second application of XRF scanning was performed to better understand the X-ray CT results. Examples of two common CT-defined lithologies were scanned at a spatial resolution of $1 \mathrm{~cm}$ (Figs. F12, F13). These lithologies differ in their CT number as well as in the textures visible on the CT images (homogeneity, burrowing, etc). "Type 1" lithology (Fig. F12) is characterized by a relatively high CT number, high uniformity, and a lack of microporosity; "Type 2 " lithology (Fig. F13) has a relatively low CT number, inhomogenous density, and abundant small micropores. XRF data revealed that the X-ray CT images are relatively insensitive to changes in sediment composition. Proportional variations in common minerals (e.g., quartz, feldspar, and calcite) correspond to variations in bulk elemental composition, but they are not reflected in discernible differences in CT number. Highly localized concentrations of more dense minerals such as pyrite are visible, however. CT number tends to be dominated by porosity, which overwhelms variations in grain density (see "X-ray computed tomography"). XRF scans required $\sim 1 \mathrm{~h}$ of technician time for setting up the scans and handling the data.

In the third application, whole-rock powders were analyzed to determine the bulk elemental composition of samples characterized by a relatively small range of XRD-determined compositions. Samples in the interval of interest contain no carbonate and have clay mineral content in a narrow range $(48 \%-$ $56 \%$ ) (Table T6). XRF data reveal no trends for 10 of the 11 elements examined. Generating these data required more time than the other two applications: $\sim 3 \mathrm{~h}$ for sample preparation, $\sim 3 \mathrm{~h}$ for machine operation, and $1 \mathrm{~h}$ for data analysis.

In the fourth application, three fine-grained black siliceous clasts from the gravel in interval 316C0007C-17H-CC, $0-5 \mathrm{~cm}$, were analyzed to provide a comparison to the XRD analysis of the same grains (Table T7). Removal of the absolute amounts of $\mathrm{Si}$, $\mathrm{Al}, \mathrm{Na}$, and $\mathrm{Ca}$ from the XRF data consistent with the XRD-determined relative amounts of quartz and feldspar (assuming all feldspar is plagioclase) leaves a residual that is in excess of the amount of clay determined from XRD (Table T7). This is not unexpected, as there may be components such as glass, mafic minerals, and oxides that are not accounted for in the XRD determination. Feldspar compositions for the individual clasts, calculated assuming that all the $\mathrm{Na}$ and $\mathrm{Ca}$ in the XRF analysis are affiliated with plagioclase, are $\mathrm{Ab}_{92}$ (possible metasedimentary clasts with albitized grains?), $A b_{76}$, and $A b_{40}$. XRF indicates less total plagioclase than XRD.

\section{Preliminary assessment of shipboard XRF}

In the case of the unconformity, data of considerable utility were generated. The scans clearly show the decline in carbonate content above and the increase in Fe mineralization (pyrite) below the unconformity.

In the second application, XRF data revealed that the $\mathrm{X}$-ray CT images are relatively insensitive to changes in lithology. Variations of lithology would be more readily detected by XRD, XRF, or even smear slides than by X-ray CT. The third application suggests that XRF may be viable as a "last resort" in cases where provenance changes are suspected but not apparent from XRD or smear slides in very fine grained materials. However, given the time required, XRF of this type may not be viable if other higher-priority tasks are pressing. Finally, in the case of the three gravel clasts, reconciling XRF with XRD would certainly benefit from petrographic information. 
XRF scanning and XRF powder analysis are highly useful but nonroutine elements of shipboard analysis. Experiences with the applications described here suggest that the most productive use of these techniques may be highly targeted use in which questions about small-scale spatial variations in elemental composition are at issue. Unconformities, erosion surfaces, seafloor precipitation crusts, and alteration halos are examples of situations in which XRF scanning might reveal the nature of processes and products that are inaccessible to visual and simple petrographic observations and for which destructive analyses such as XRD may be undesirable.

\section{Structural geology}

Our methods for documenting the structural geology of Expedition 316 cores largely followed those given by the Expedition 315 structural geologists (see "Structural geology" in the "Expedition 315 methods" chapter). We documented the deformation observed in the split cores by classifying structures, determining the depth extent, measuring orientation data, and recording kinematic information. The collected data were hand logged onto a printed form at the core table and then typed into both a spreadsheet and the J-CORES database. Where possible, the orientation data were also corrected for rotations related to drilling on the basis of paleomagnetic declination and inclination information.

\section{Core description and orientation data collection}

Each structure was recorded manually on a structural description sheet modified from that used during Expedition 315 (Fig. F14). We found that this modified sheet is particularly useful to record orientation data for linear structures (e.g., striation on the fault plane). Core measurements followed Expedition 315, which in turn were based on previous ODP procedures developed at the Nankai accretionary margin (i.e., ODP Legs 131 and 190). We used a plastic protractor for orientation measurements (Fig. F15). During Expedition 316, we downloaded the X-ray CT images of unsplit cores from the database on the Chikyu to identify structures and recognize 3-D geometry and distribution of structures. Using the working half of the split core provided greater flexibility in removing - and cutting, if necessary-pieces of the core for more careful study and measurement.

Orientations of planar and linear features in cored sediments were determined relative to the core axis, which represents vertical in the core reference frame, and the "double line" marked on the working half of the split core liner, which represents north (or $0^{\circ}$ and $360^{\circ}$ ) in the core reference frame (Fig. F16). To determine the orientation of a plane, two apparent dips of the planar feature were measured in the core reference frame and converted to a plane represented by either a strike and dip or a dip and dip direction. This conversion was accomplished using a spreadsheet (Fig. F17). This approach had the advantage of increasing the data processing efficiency and reducing errors in transferring and retyping data (e.g., by using both R. Allmendinger's Stereonet program [www.geo.cornell.edu/geology/faculty/RWA/programs.html] and a spreadsheet). One apparent dip was typically represented by the intersection of the planar feature with the split face of the core and was quantified by measuring the dip direction and angle in the core reference frame. Typical apparent dip measurements had a trend of $090^{\circ}$ or $270^{\circ}$ and ranged in plunge from $0^{\circ}$ to $90^{\circ}$. The second apparent dip was usually represented by the intersection of the planar feature and a cut or fractured surface at a high angle to the split face of the core axis. In many cases, this was a surface either parallel or perpendicular to the core axis. In the former cases, the apparent dip lineation would trend $000^{\circ}$ or $180^{\circ}$ and plunge from $0^{\circ}$ to $90^{\circ}$; in the latter cases, the trend would range from $000^{\circ}$ to $360^{\circ}$ and plunge $0^{\circ}$. Linear features observed in the cores were always associated with planar structures (typically faults or shear zones), and their orientations were determined by measuring either the trend and plunge in the core reference frame or the rake (or pitch) on the associated plane. All data were recorded on the log sheet with appropriate depths and descriptive information.

Paleomagnetic data were routinely used to correct drilling-induced rotations of cored sediments. Rotations were induced during RCB and ESCS coring, as is common in ocean drilling. In cases where core sections were not continuous (generally this included core sections $<10 \mathrm{~cm}$ long), individual samples were placed in a core liner at $20 \mathrm{~cm}$ intervals, which is the sampling length of the long-core cyrogenic magnetometer on the Chikyu.

\section{Orientation data analysis based on the spreadsheet}

During Expedition 316, we adopted the Expedition 315 spreadsheet template for orientation data calculation in the core reference frame, as well as in the geographic reference frame from those data measured on cores (e.g., Fig. F17). The core reference frame is such that the upcore direction is vertical upward, the core-splitting plane is east-west vertical, and the double-lined side of the working half points toward north (Fig. F16). 


\section{Calculation of plane orientation}

For planar structures (e.g., bedding or faults), two apparent dips on two different surfaces (e.g., one being the split core surface, which is east-west vertical, and the other being the horizontal or north-south vertical surface) were measured in the core reference frame as azimuths (measured clockwise from north, looking down) and plunges (Fig. F18). A coordinate system was defined in such a way that the positive $x_{-}, y-$, and $z$-directions coincide with north, east, and vertical downward, respectively (Fig. F16). If the azimuths and plunges of the two apparent dips are given as $\left(\alpha_{1}, \beta_{1}\right)$ and $\left(\alpha_{2}, \beta_{2}\right)$, respectively, as in Figure F18, then the unit vectors representing these two lines, $v_{1}$ and $v_{2}$, are

$$
v_{1}=\left(\begin{array}{c}
l_{1} \\
m_{1} \\
n_{1}
\end{array}\right)=\left(\begin{array}{c}
\cos \alpha_{1} \cos \beta_{1} \\
\sin \alpha_{1} \cos \beta_{1} \\
\sin \beta_{1}
\end{array}\right)
$$

and

$$
v_{2}=\left(\begin{array}{c}
l_{2} \\
m_{2} \\
n_{2}
\end{array}\right)=\left(\begin{array}{c}
\cos \alpha_{2} \cos \beta_{2} \\
\sin \alpha_{2} \cos \beta_{2} \\
\sin \beta_{2}
\end{array}\right) .
$$

The unit vector normal to this plane, $v_{\mathrm{n}}$ (Fig. F18), is then defined as follows:

$$
v_{\mathrm{n}}=\left(\begin{array}{c}
l_{\mathrm{n}} \\
m_{\mathrm{n}} \\
n_{\mathrm{n}}
\end{array}\right)=\frac{v_{1} \times v_{2}}{\left|v_{1} \times v_{2}\right|},
$$

where

$$
v_{1} \times v_{2}=\left(\begin{array}{cc}
\left|\begin{array}{cc}
m_{1} & m_{2} \\
n_{1} & n_{2}
\end{array}\right| \\
\left|\begin{array}{cc}
n_{1} & n_{2} \\
l_{1} & l_{2}
\end{array}\right| \\
\left|\begin{array}{cc}
l_{1} & l_{2} \\
m_{1} & m_{2}
\end{array}\right|
\end{array}\right)=\left(\begin{array}{c}
m_{1} n_{2}-m_{2} n_{1} \\
n_{1} l_{2}-n_{2} l_{1} \\
l_{1} m_{2}-l_{2} m_{1}
\end{array}\right) .
$$

The azimuth, $\alpha_{n}$, and plunge, $\beta_{n}$, of $v_{n}$ are given by

$$
\alpha_{\mathrm{n}}=\tan ^{-1}\left(\frac{m_{\mathrm{n}}}{l_{\mathrm{n}}}\right), \beta_{\mathrm{n}}=\sin ^{-1} n_{\mathrm{n}} .
$$

The dip direction, $\alpha_{d}$, and dip angle, $\beta$, of this plane are $\alpha_{n}$ and $90^{\circ}+\beta_{n}$, respectively, when $\beta_{n}$ is $<0^{\circ}$ (Fig. F19A). They are $\alpha_{n} \pm 180^{\circ}$ and $90^{\circ}-\beta_{n}$, respectively, when $\beta_{\mathrm{n}}$ is $\geq 0^{\circ}$ (Fig. F19B). The right-hand rule strike of this plane, $\alpha_{s}$, is then given by $\alpha_{d}-90^{\circ}$ (Fig. F19).

\section{Calculation of slickenline rake}

For a fault with slickenlines, the apparent rake angle of the slickenline, $\phi_{a}$, was measured on the fault surface from either the $090^{\circ}$ or $270^{\circ}$ direction of the split-core surface trace (Fig. F20). Fault orientation was measured as described above. Provided that $v_{n}$ and $v_{\mathrm{c}}$ are unit vectors normal to the fault and split core surfaces, respectively, the unit vector of this intersection line, $v_{\mathrm{i}}$, is perpendicular to both $v_{\mathrm{n}}$ and $v_{\mathrm{c}}$ (Fig. F20) and is therefore defined as follows:

where

$$
v_{\mathrm{i}}=\left(\begin{array}{c}
l_{\mathrm{i}} \\
m_{\mathrm{i}} \\
n_{\mathrm{i}}
\end{array}\right)=\frac{v_{\mathrm{n}} \times v_{\mathrm{c}}}{\left|v_{\mathrm{n}} \times v_{\mathrm{c}}\right|},
$$

and

$$
v_{\mathrm{c}}=\left(\begin{array}{l}
1 \\
0 \\
0
\end{array}\right)
$$

$$
v_{\mathrm{n}} \times v_{\mathrm{c}}=\left(\begin{array}{cc}
\left|\begin{array}{cc}
m_{\mathrm{n}} & 0 \\
n_{\mathrm{n}} & 0
\end{array}\right| \\
\left|\begin{array}{cc}
n_{\mathrm{n}} & 0 \\
l_{\mathrm{n}} & 1
\end{array}\right| \\
\left|\begin{array}{cc}
l_{\mathrm{n}} & 1 \\
m_{\mathrm{n}} & 0
\end{array}\right|
\end{array}\right)=\left(\begin{array}{c}
0 \\
n_{\mathrm{n}} \\
-m_{\mathrm{n}}
\end{array}\right) .
$$

Knowing the right-hand rule strike of the fault plane, $\alpha_{s}$, the unit vector, $v_{s}$, toward this direction is then

$$
v_{\mathrm{s}}=\left(\begin{array}{c}
\cos \alpha_{\mathrm{s}} \\
\sin \alpha_{\mathrm{s}} \\
0
\end{array}\right) \text {. }
$$

The rake angle of the intersection line, $\phi_{\mathrm{i}}$, measured from the strike direction is given by

$$
\phi_{\mathrm{i}}=\cos ^{-1}\left(v_{\mathrm{s}} \times v_{\mathrm{i}}\right)
$$

because

$$
v_{\mathrm{s}} \times v_{\mathrm{i}}=\left|v_{\mathrm{s}}\right|\left|v_{\mathrm{i}}\right| \cos \phi_{\mathrm{i}}=\cos \phi_{\mathrm{i}}, \therefore\left|v_{\mathrm{s}}\right|=\left|v_{\mathrm{i}}\right|=1 .
$$

The rake angle of the slickenline, $\phi$, from the strike direction is $\phi_{i} \pm \phi_{a}$, depending on which direction the apparent rake was measured from and which direction the fault plane dips toward. $\phi_{a}$ should be subtracted from $\phi_{\mathrm{i}}$ when the fault plane dips toward west and $\phi_{a}$ was measured from either the top or $090^{\circ}$ direction (Fig. F21A) or when the fault plane dips toward east and $\phi_{\mathrm{a}}$ was measured from either the bottom or $090^{\circ}$ direction (Fig. F21B). On the other 
hand, $\phi_{a}$ should be added to $\phi_{\mathrm{i}}$ when the fault plane dips toward east and $\phi_{\mathrm{a}}$ was measured from either the top or $270^{\circ}$ direction (Fig. F21C) or when the fault plane dips toward west and $\phi_{a}$ was measured from either the bottom or $270^{\circ}$ direction (Fig. F21D).

\section{Azimuth correction using paleomagnetic data}

Provided that a core is vertical, its magnetization is primary, and its bedding is horizontal, its paleomagnetic declination, $\alpha_{p}$, indicates magnetic north when its inclination, $\beta_{p}$, is $\geq 0^{\circ}$ (Fig. F22A), whereas it indicates magnetic south when $\beta_{p}$ is $<0^{\circ}$ (Fig. F22B). The dip direction and strike of a plane in the geographic reference frame, $\alpha_{d}{ }^{*}$ and $\alpha_{s}{ }^{*}$, are therefore

$$
\alpha_{d}^{*}=\alpha_{d}-\alpha_{p}
$$

and

$$
\alpha_{s}^{*}=\alpha_{s}-\alpha_{p}
$$

when

$$
\beta_{p} \geq 0^{\circ}
$$

and are

$$
\alpha_{d}{ }^{*}=180^{\circ}+\alpha_{d}-\alpha_{p}
$$

and

$$
\alpha_{s}^{*}=180^{\circ}+\alpha_{s}-\alpha_{p}
$$

when

$$
\beta_{p}<0^{\circ} \text {. }
$$

\section{J-CORES structural database}

Structural data entered in the J-CORES database VCD program include a visual (macroscopic and/or microscopic) description of core structures at a given section index and a record of planar structures in the core reference frame. Tablet PCs equipped with a wireless interface and writing recognition software were provided to allow data input directly from the core description tables. As pointed out by Expedition 315 structural geologists, however, we found it more efficient to record the data on paper logs first and then transfer the data into the J-CORES database at a later time. Data were also entered into a spreadsheet (Fig. F17) for postacquisition processing.

Data entry through the VCD program proceeds as follows:

1. Select expedition, site, hole, core, and section for which data will be read/written.
2. Select data to work with (i.e., deformation structure description) and click on Hire and OK.

3. Select a structure identifier (ID) (e.g., bedding, fault) or create a new structure ID.

4. Select the section interval in which the structure is observed.

5. Fill the parameters related to this particular structure (comments and planar data; Fig. F23).

After saving, data are automatically uploaded to the Chikyu server and can be retrieved afterward as text or as an Excel file for processing. It is important to note that scientists are only allowed to write data in their own field of research and for their expedition (e.g., an Expedition 316 structural geologist can input only structural data for Expedition 316). Any loggedin user has "read" access to the entire database.

\section{Description and classification of structures}

From a lithological point of view, the cores recovered during Expedition 316 predominantly consist of unconsolidated to slightly consolidated material. Thus the lithology description does not use the suffix "stone." However, from a structural geology point of view, the deformation style of most of the materials retrieved from depths larger than $\sim 100 \mathrm{~m}$ (by ESCS or RCB methods) is clearly brittle without any soft deformation structures. Such a mechanical response prompts us to add the suffix "stone" to lithologic substantives, at least for cores retrieved from below slope sediments.

In general, we described and classified the structures observed using the terminology of J-CORES and Expedition 315, which in turn is based on the J-DESC VCD scheme and ODP Legs 131 (Taira, Hill, Firth, et al., 1991), 156 (Shipley, Ogawa, Blum, et al., 1995), 170 (Kimura, Silver, Blum, et al., 1997), and 190 (Moore, Taira, Klaus, et al., 2001). For clarity, however, we define the terminology used to describe fault-related rocks, as well as the basis for differentiating natural and drilling-induced features. The key to the symbols used in J-CORES is given in Figure F24.

\section{Tectonic breccias and gouges}

Tectonic breccias and gouges include four types of deformed rocks: protobreccias, breccias, microbreccias, and gouges.

Protobreccias consist of angular to subangular fragments of centimeter size with little or no matrix in between. Fragment surfaces are commonly polished or striated. On CT images, the original structure of the rock can still be recognized. In particular, there is no evidence for fragment rotation. Protobreccias are transitional between fractured rocks and true breccias. Breccias are composed of fragments with a 
mean length of $\sim 5 \mathrm{~mm}$. The presence of a matrix is difficult to ascertain when pervasive intrusion of drilling mud occurred. The fragments have striated surfaces and may exhibit an incipient spaced cleavage. Microbreccias consist of fine fragments (less than $\sim 1 \mathrm{~mm}$ long) embedded in a light green to light gray clayey matrix. With increasing clay content and decreasing size of fragments, microbreccia can transition to fault gouge, which consists of a very fine grained and commonly clayey product inside which fragments are not macroscopically recognizable.

The recognition of tectonic breccias and gouges in cores is of primary importance because it constitutes a straightforward way to locate fault zones and, more precisely, principal slip zones (so-called fault cores) where displacement is supposed to be maximum. This recognition, easily done in the field on land, appears to be less trivial in cores, mainly because of frequent drilling-induced or splitting-induced brecciation and/or drilling mud injection; both processes tend to produce structures that mimic natural products. During Expedition 316, the distinction between tectonic breccias and induced breccias was based on a set of criteria that includes

- Fragments observed in tectonic breccias commonly show polished or striated faces;

- Fragments tend to be more rounded than those from drilling-induced breccias;

- CT images of tectonic breccias are characterized by much lower contrast in CT number between fragments and a matrix compared to drillinginduced breccia; and

- Tectonic breccias often are bounded by, and grade into, less fractured rock, and the fracture fabrics in the bounding rocks display preferred orientations.

The distinction between tectonic gouge and drillinginduced mud is delicate:

- Drilling mud is commonly present at the periphery of cores or as veins injected across core pieces and perpendicularly to the core axis;

- Transition between drilling mud and surrounding rock is usually sharp;

- CT number of drilling mud is much lower than that of tectonic gouge;

- Natural gouges transition progressively to surrounding rock, which consist in most cases of fault breccia or microbreccia; and

- Natural gouges either lack or have very small ( $<1 \mathrm{~mm}$ long) fragments.

\section{Minor faults}

It may be difficult to distinguish natural faults from drilling-induced faults. Helicoidal striated surfaces or polished surfaces showing striations that diverge outward most likely indicate drilling-induced fracturing resulting from the torque exerted by the bit on sediments. In contrast, faults that display more planar geometries, parallel lineations, and orientations compatible with preferred orientations displayed by multiple faults nearby are likely natural features. Lastly, when multiple orientation measurements are plotted in stereographic projection, natural minor faults are expected to display preferred orientations that may define coherent strain axes, whereas drilling-induced faults are expected to yield random orientation distributions.

\section{Biostratigraphy}

During Expedition 316, calcareous nannofossils and radiolarians were systematically studied to assign preliminary ages to core catcher samples. Samples from within the cores were examined when a more refined age determination was necessary.

\section{Timescale and biohorizons}

Biostratigraphic zones of calcareous nannofossils of sedimentary sequences recovered during Expedition 316 mainly follow the timescale used by biostratigraphic studies carried out during Expedition 315 (see "Biostratigraphy" in the "Expedition 315 methods" chapter). Ages for biostratigraphic data were compiled mainly from the recent review by Raffi et al. (2006). Biostratigraphic zonation of calcareous nannofossils is based on the studies of Martini (1971) and Okada and Bukry (1980) with zonal modifications by Young (1999).

Radiolarian zonation used in this study follows that presented for middle to high latitudes in Kamikuri et al. (2004). Additional biohorizons, including some characteristics species used in tropical zonation (Nigrini and Sanfilippo, 2001), were employed and calibrated into the standard geomagnetic polarity timescale (GPTS). The lower boundary of the Botryostrobus acquilonaris Zone is defined by the last occurrence (LO) of Stylatractus universus. The first occurrence (FO) of Eucyrtidium matuyamai defines the upper boundary of the Eucyrtidium matuyamai Zone. Although characteristic species do not necessarily occur in the studied radiolarian assemblages, additional biohorizons, such as the occurrence/co-occurrence of Lamprocyrtis neoheteroporos, Lamprocyrtis heteroporos, and Anthocyrtidium angulare, places an assemblage into the lower part of the Stylatractus universus Zone to the Eucyrtidium matuyamai Zone.

Diatom zonation used during ODP Leg 186 (Maruyama and Shiono, 2003) for the North Pacific was used as a reference for diatom zonation during this 
expedition. Because characteristic species were not found in this area, we used additional events (Barron, 1985) and co-occurrence of taxa to identify diatom biohorizons in the studied assemblages.

Biostratigraphic zones of planktonic foraminifers used during Expedition 316 are based on the timescale used during Expedition 315 (see "Biostratigraphy" in the "Expedition 315 methods" chapter). This is derived from the planktonic foraminfer zonation presented in Blow (1969).

Astrochronological age estimates for the Neogene rely on the geologic timescale developed by the International Commission on Stratigraphy (ICS) in 2004 (Lourens et al., 2004).

The timescale and biostratigraphic zones of calcareous nannofossils and radiolarians are summarized in Figure F25 and Tables T8 and T9.

\section{Calcareous nannofossils}

\section{Taxonomic remarks}

Several species of the genera Gephyrocapsa are commonly used as Pleistocene biostratigraphic markers. Species of the genera show a great range of variation in sizes and other morphological features, causing problems in identification (Su, 1996). Size-defined morphological groups of this genera suggested by Young (1999) were used during shipboard study, including Gephyrocapsa spp. medium I ( $>3.5$ to $<4 \mu \mathrm{m})$, Gephyrocapsa spp. medium II ( $\geq 4.5$ to $<5.5 \mu \mathrm{m})$, and Gephyrocapsa spp. large ( $\geq 5.5 \mu \mathrm{m})$. Reticulofenestra pseudoumbilicus is identified by specimens having a maximum coccolith length $>7 \mu \mathrm{m}$ in its uppermost range (the lower Pliocene) and also following the suggestion of Young (1999). Identification of other calcareous nannofossils mainly follows the compilation of Perch-Nielsen (1985).

\section{Methods}

Standard smear slides were made for all samples using photocuring adhesive as a mounting medium.

In addition, a concentration method was applied to extract more nannofossils from fine sand or silt samples before making smear slides because sediments recovered from Expedition 316 are dominated by interbedded sand layers and volcanic ash layers in turbidite sequences, yielding few to rare nannofossils in most samples from core catchers and within cores. About 1-5 g of sediment was placed in a beaker with distilled water and stirred for several seconds to suspend the sample. The suspension was left to sit for a few minutes, so sand-sized particles could settle to the bottom first and small-sized nannofossils were floated and concentrated in the upper part of the suspension. Several drops from the upper part of the suspension were taken for making smear slides.

Calcareous nannofossils were examined using standard light microscope techniques under crossed polarizers and transmitted light at $250 \times$ to $2500 \times$ magnification with a Zeiss Axio Imager.A1m.

Abundance and preservation of nannofossils from the core catcher samples investigated were recorded in the J-CORES database. The degrees of calcareous nannofossil species preservation were based on the following:

VG = very good preservation (no evidence of dissolution and/or overgrowth).

$\mathrm{G}=$ good preservation (slight dissolution and/or overgrowth; specimens are identifiable to the species level).

$\mathrm{M}=$ moderate preservation (exhibit some etching and/or overgrowth; most specimens are identifiable to the species level).

$\mathrm{P}=$ poor preservation (severely etched or with overgrowth; most specimens cannot be identified at the species and/or generic level).

Group abundance (at 250× magnification) and relative abundance of individual calcareous nannofossil species (at 1250× magnification) are estimated based on the following scale:

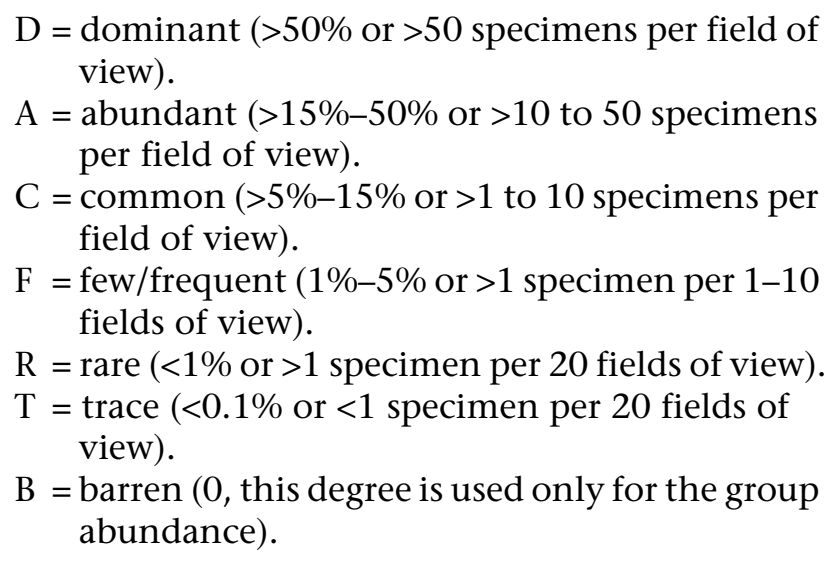

\section{Radiolarians}

\section{Methods}

All core catchers were prepared for radiolarian determination using $5-10 \mathrm{~cm}^{3}$ of sediment. Samples were disaggregated in a solution containing $\mathrm{H}_{2} \mathrm{O}_{2}$ and Calgon until completion of the reaction. The coalesced solution was then sieved through a $63 \mu \mathrm{m}$ mesh sieve. In case of aggregated sediments, these steps were repeated until complete disaggregation. A subsample was then kept in solution for radiolarian examination, while the rest was filtered and dried for further examination. The radiolarian-bearing solution was directly mounted onto standard cover-slipped microscope slides. 
From all the core catcher samples prepared and kept in solution, few representative samples were selected and dried to pick radiolarian specimens and check their preservation. Highly silicified and spongeous shells were chosen for this analysis, as they occur consistently in poorly and well-preserved radiolarianbearing samples.

There has been no attempt to systematically quantify the relative abundance of radiolarians because of the large species diversity and variable preservation throughout the site. Total radiolarian assemblage composition ( $>63 \mu \mathrm{m})$ was assessed as follows:

$$
\begin{aligned}
& \mathrm{R}=\text { rare, } 1 \%-5 \% . \\
& \mathrm{C}=\text { common, } 6 \%-10 \% . \\
& \mathrm{A}=\text { abundant, }>10 \% .
\end{aligned}
$$

Radiolarian species composition was assessed as follows:

$\mathrm{X}=$ species present .

$++=$ noticeable large abundance of the species.

Preservation of each sample was recorded using the following:

$\mathrm{P}=$ poor, abundant fragments, no fragile forms.

$\mathrm{M}=$ moderate, fragmentation occurs, but species identification stays possible.

$\mathrm{G}=$ good, fragile forms are present, fragmentation appears weak.

\section{Other microfossils}

In the case of foraminifer-bearing sediments (core catcher and discrete samples), radiolarian preparations were dried and residues were inspected for foraminfer biostratigraphic markers.

For diatom-bearing sediments, samples were set in a solution with water. The solution was then pipetted and directly mounted onto standard cover-slipped microscope slides. There has been no attempt to systematically quantify the relative abundance of diatoms.

Diatom occurrence was assessed as follows:

$\mathrm{X}=$ present.

$++=$ noticeable large abundance of the species.

Preservation of each sample was recorded using the following:

$\mathrm{P}=$ poor, abundant fragments, no fragile forms.

$\mathrm{M}=$ moderate, fragmentation occurs, but species identification stays possible.

$\mathrm{G}=$ good, fragile forms are present, fragmentation appears weak.

\section{Paleomagnetism}

Paleomagnetic and rock magnetic investigations on board the Chikyu during Expedition 316 were primarily designed to (1) determine the characteristic remanence directions for use in magnetostratigraphic and tectonic studies and (2) assess the orientation and significance of magnetic fabrics. To accomplish these goals, paleomagnetic measurements were performed on all continuous pieces of archive halves and on discrete minicore and cube samples taken from the working halves.

\section{Magnetic measurements}

Remanent magnetization was measured using the shipboard 2G Enterprises (model 760R) long-core cryogenic magnetometer equipped with directcurrent superconducting quantum interference devices (DC-SQUIDs) and an inline automated alternatingfield (AF) demagnetizer capable of reaching a peak field of $80 \mathrm{mT}$. The response curve from the sensor coils of the cryogenic magnetometer was measured and corresponds to a region $\sim 20 \mathrm{~cm}$ wide (Fig. F26); therefore, only measurements taken every $20 \mathrm{~cm}$ are independent from each other. Measurements at core and section ends, whole-round locations and voids, and within intervals of drilling-related core disturbance were not taken or were removed from the data set during data processing. The relatively large volume of core material within the sensing region compensates for the relatively high background noise, and with very few exceptions sediment magnetization was well above the instrumental noise level. Archive halves were measured at $5 \mathrm{~cm}$ intervals. This sampling interval coincides roughly with that used on the MSCL track $(\sim 4 \mathrm{~cm}$; see "Physical properties") so that susceptibility and remanence data may easily be compared. Results from the remnant magnetization and low-field susceptibility measurements were compared with lithologic units and/or geologic structures. Remnant magnetization directions were fit using principal component analysis (Kirschvink, 1980).

In addition to standard paleomagnetic measurements, the anisotropy of magnetic susceptibility was determined for several representative discrete samples using the Kappabridge KLY 3 magnetic susceptibility meter.

\section{Sampling coordinates}

The orientation of the Chikyu's long-core magnetometer (Fig. F27) is the standard IODP core orientation. All magnetic data are reported relative to the following core coordinates: $+x$ (north on plots) is into the face of the archive half of the core, $+y$ (east on plots) points toward the left side of the face of the archive half, and $+Z$ is downcore (Fig. F27). The "flipping" function of the control software (Long Core version 3.4) enables $180^{\circ}$ rotation of the $x$ - and $y$ axes about the $z$-axis. By using this flipping function, 
working and archive halves can be measured in the same coordinate system. AF demagnetization on the archive halves was performed routinely with the inline AF demagnetizer at typical fields of up to $40 \mathrm{mT}$. Occasionally we reached $60 \mathrm{mT}$ on working half samples taken from intervals where a more precise direction was needed for structural correction purposes. Such a high AF value was required to overcome the drilling-induced overprint (e.g., see "Paleomagnetism" in the "Expedition 316 Site C0004" chapter).

\section{Paleomagnetic core reorientation}

Azimuthal orientation of drilled core material is of great importance when modeling directional properties of rock formations. Paleomagnetism can be used to determine the core azimuth by providing a reference direction from the drilled rocks. Paleomagnetic core reorientation has been used successfully for a number of years (e.g., Fuller, 1969; Kodama, 1984; Shibuya et al., 1991). The procedure is based on determining the direction of stable remanent magnetization (either viscous remanent magnetization or primary magnetization) with respect to a common reference line that is scribed the length of the core. Provided that the reference magnetic pole is known, the orientation of the paleomagnetic vector is then used to restore the core azimuth. The horizontal component of the mean characteristic remanent magnetization (ChRM) direction makes an angle with the reference line, which specifies the rotation of the core relative to the geographic coordinates.

To restore core orientation to geographic coordinates, the mean paleomagnetic direction is computed for samples sharing a common reference line. We systematically used the archive half, which is marked at the bottom with a single reference line (the working half has a double line). After visual inspection of the AF demagnetization plots, we determined whether the blanket demagnetization at the highest peak (typically $40 \mathrm{mT}$ ) truly reflects the ChRM of the sediments. The uppermost and lowermost measurements have been typically disregarded to avoid end-core effects.

Our assumptions are as follows:

- The true paleomagnetic direction points to present-day geographic north. A given section has enough measurements to average secular variation.

- Bedding is horizontal or subhorizontal.

- Core is vertical.

- Sedimentary unit is in situ and has not experienced any vertical axis rotation.
Physical properties of the cored sediment, including voids, drilling disturbance, and flow-in, have determined to a large extent the applicability of the paleomagnetic method for core reorientation. Hence, our "mean directions" are based on the statistical analysis of individual sections (from $\sim 30$ to $150 \mathrm{~cm}$ long) only when there is no visual evidence for general core disturbance or twisting.

For intervals of particular interest for structural geology (see "Structural geology") we have taken two different approaches for core reorientation:

1. Discrete samples: small cubic $\left(8 \mathrm{~cm}^{3}\right)$ samples were cut from the working half in order to determine paleomagnetic direction. We used the "discrete sample" option of the superconducting rock magnetometer (SRM), which allows automatic measurement of up to six samples, 20 $\mathrm{cm}$ apart.

2. Biscuits: for homogeneous segments containing structures that had to be reoriented (see "Structural geology"), we measured entire (up to 15 $\mathrm{cm})$ core segments. In this case, we measured the samples as "continuous samples" in the SRM, also $20 \mathrm{~cm}$ apart.

\section{Magnetic reversal stratigraphy}

Magnetic polarity was determined using inclinationonly data from continuous core measurements. Site C0004 has a latitude of $33^{\circ} 13.9^{\prime} \mathrm{N}$, which translates into an expected inclination of $\sim 52.6^{\circ}$ for at least Neogene and Quaternary sediments. This inclination is steep enough to distinguish the magnetic polarities (normal or reversed) on the sign of the magnetic inclination (positive or negative).

Typical steps used to establish magnetic reversal stratigraphy included the following:

1. Complete visual inspection for stable remanent magnetization on the demagnetization plots (e.g., Zijderveld plots) using the Long Core software.

2. Obtain remanent magnetization directions after $20 \mathrm{mT}$ or highest (40 mT) demagnetization step and group them by sections.

3. Locate disturbed and "flow-in" intervals in core descriptions and discard those intervals from the data set also, for RCB cored sediments, determine the position of biscuits in order to group the paleomagnetic data accordingly.

4. Exclude the top and bottom $\sim 15 \mathrm{~cm}$ (response of the pick up coils is $\sim 20 \mathrm{~cm}$ ) to avoid end-core edge effects.

5. Check that there are at least four consecutive data points (= measuring intervals) with the same inclination sign to define a polarity chron. 
Whenever possible, we offer an interpretation of the magnetic polarity, with the naming convention consisting of correlative anomaly numbers prefaced by the letter C (Tauxe et al., 1984). Normal polarity subchrons are referred to by adding suffixes (e.g., n1, n2) that increase with age. For the younger part of the timescale (Pliocene-Pleistocene) we often use traditional names to refer to the various chrons and subchrons (e.g., Brunhes, Jaramillo, Olduvai, etc.). In general, polarity reversals occurring at core ends have been treated with extreme caution.

The ages of the polarity intervals used during Expedition 316 are the same as Expedition 315, which are a composite of four previous magnetic polarity timescales. We used the Gradstein et al. (2004) timescale (Table T10).

\section{Discrete samples}

Discrete sampling ("routine sampling") was completed for shore-based detailed studies. On average, about one standard sample $\left(\sim 8 \mathrm{~cm}^{3}\right)$ was taken every core section, but the actual spacing largely depended on the properties of the core material (e.g., flow-in, coring disturbances, etc.) and the preliminary paleomagnetic record obtained with the pass-through magnetometer. A few pilot specimens were demagnetized on board using both AF and thermal demagnetization. Results are shown in the corresponding site chapter summaries.

\section{Data reduction and software}

Data visualization (standard As-Zijderveld demagnetization plots) is possible because of the Long Core software that controls the SRM. However, that facility does not allow computation of ChRM directions. The following programs have been used to interpret data (Tauxe, 1998):

- "plotdmag" makes orthogonal and equal area projections of input demagnetization data.

- "boodi" calculates bootstrap statistics for a group of vectors.

- "plotdi" makes equal area plots of data, with uncertainties.

- "pca" calculates best-fit line through specified data.

- "incfish" estimates the Fisher mean inclination and 95\% confidence bounds from inclination only data using the method of McFadden and Reid (1982).

\section{Laboratory instruments}

The Paleomagnetism laboratory on board the Chikyu houses a large $(7.3 \mathrm{~m} \times 2.8 \mathrm{~m} \times 1.9 \mathrm{~m})$ magnetic shielded room, with its long axis parallel to the ship transverse. The total magnetic field inside the room is $\sim 1 \%$ of Earth's magnetic field. The room is large enough to comfortably handle standard IODP long sections $(\sim 150 \mathrm{~cm})$. The shielded room houses the equipment, instruments, and ancillary items described in this section.

\section{Superconducting rock magnetometer}

The $8.1 \mathrm{~cm}$ long-core superconducting rock magnetometer (2G Enterprises, model 760) unit is $\sim 6 \mathrm{~m}$ long. A $1.5 \mathrm{~m}$ split core liner can pass through a magnetometer, an AF demagnetizer, and an anhysteretic remanent magnetizer. The system includes three sets of superconducting pickup coils, two for transverse movement measurement ( $x$ - and $y$-axes) and one for axial moment measurement (z-axis). These pickup coils have a large volume of uniform response to a small magnetic dipole. When a rock is inserted into the pickup coil region, persistent currents are generated in all three pickup coils. To prevent magnetic noise from being picked up from sources other than rocks inserted into the system, both the pickup and coil structures and DC-SQUID sensors have superconducting shields placed around them. The noise level of the magnetometer is $<10^{-7}$ $\mathrm{mA} / \mathrm{m}$ for a $10 \mathrm{~cm}^{3}$ volume rock. The SRM dewar system has a capacity of $90 \mathrm{~L}$ of liquid helium. The magnetometer includes an automated sample handler system (2G804) consisting of aluminum and fiberglass channels designated to support and guide long core movement. The core itself is positioned in a nonmagnetic fiberglass carriage that is pulled through the channels by a pull rope attached to a geared high-torque stepper motor.

A 2G600 sample degaussing system is coupled to the SRM to allow automatic demagnetization of samples up to $300 \mathrm{mT}$ with a standard air-cooled solenoid (model 2G601S), and up to $180 \mathrm{mT}$ with a transverse split pair (model 2G601T). The system is completely controlled by an external computer. Because it is used with the automatic sample handler, a complete sequence of measure and degauss cycles can be completed without removing the long core from the holder.

A 615 anhysteretic remanent magnetization (ARM) system is included to enable magnetization of rock samples during demagnetization. Magnetization is achieved by applying a direct current (DC) magnetic field in the range of 0 to \pm 4 Gauss during the degaussing process.

\section{Spinner magnetometer}

A spinner magnetometer, model SMD-88 (Natsuhara Giken Co., Ltd.) is also available for remanent mag- 
netization measurement. The noise level is $\sim 5 \times 10^{-7}$ emu, and the measurable range is from $5 \times 10^{-6}$ to $3 \times$ $10^{-1} \mathrm{~mA} / \mathrm{m}^{2}$. Five standard samples with different intensities are prepared to calibrate the magnetometer. Standard $2.5 \mathrm{~cm}$ diameter $\times 2.1 \mathrm{~cm}$ long samples can be measured in three or six positions, the hole sequence taking $\sim 1$ and $2 \mathrm{~min}$, respectively. Remanent intensity of Expedition 316 samples prevented the use of the spinner magnetometer.

\section{Alternating-field demagnetizer}

The alternating-field demagnetizer DEM-95 (Natsuhara Giken Co., Ltd.) is set for demagnetization of standard discrete samples of rock or sediment. The unit is equipped with a sample tumbling system to uniformly demagnetize up to an AF peak of $180 \mathrm{mT}$.

\section{Anhysteretic remanent magnetization}

The DTECH alternating-field demagnetizer D-2000 can be used to impart ARM to discrete samples, in which a DC magnetic field is produced continuously across the AF demagnetizer coil. The user can select the demagnetization interval over which the field is applied (maximum $\mathrm{AF}=200 \mathrm{mT}$, maximum DC field $=1.5 \mathrm{mT}$ ), producing partial anhysteretic remanent magnetization.

\section{Thermal demagnetizer}

The thermal demagnetizer TDS-1 (Natsuhara Giken Co., Ltd.) has a single chamber for thermal demagnetization of dry samples over a temperature range from room temperature to $800^{\circ} \mathrm{C}$. The chamber holds up to 8 or 10 cubic or cylindrical samples, depending on the exact size. The oven requires a closed system of cooling water, which is conveniently placed next to the shielded room. A fan next to the $\mu$-metal cylinder that houses the heating system is used to cool the samples to room temperature. The measured magnetic field inside the chamber is not $>10$ nT.

\section{Anisotropy of magnetic susceptibility system}

The Kappabridge KLY 3, designed for anisotropy of magnetic susceptibility (AMS) measurement, is also available. Data are acquired from spinning measurements around three different axes. Deviatoric susceptibility tensor can then be computed. An additional measurement for bulk susceptibility completes the sequence. Sensitivity for AMS measurement is $2 \times 10^{-8}$ (SI). Intensity and frequency of field applied are $300 \mathrm{~mA} / \mathrm{m}$ and $875 \mathrm{~Hz}$, respectively. This system also includes the temperature control unit (CS-3) for temperature variation of low-field magnetic susceptibility of samples.

\section{Pulse magnetizer}

The pulse magnetizer MMPM10 (Magnetic Measurement Ltd.) can produce a high magnetic field. A maximum field of $9 \mathrm{~T}$ with a $7 \mathrm{~ms}$ pulse duration can be produced by the $1.25 \mathrm{~cm}$ diameter coil. The $3.8 \mathrm{~cm}$ coil generates a maximum field of $2.9 \mathrm{~T}$. We did not use this apparatus during Expedition 316, as it has not been operative since Expedition 315.

\section{Fluxgate magnetometer}

The Walker portable three-axis fluxgate magnetometer (model FGM-5DTAA) measures small ambient fields with a range of $\pm 100 \mu \mathrm{T}$ and a sensitivity of $1 \mathrm{nT}$. The sensor fits into small spaces, such as the sample access tube of the cryogenic magnetometer. The magnetometer was also used to monitor the total field in the shielded room and as a thermal demagnetizer.

\section{Hall-effect magnetometer}

A Hall-effect magnetometer (model MG-5DP), capable of measuring DC and alternating current fields over three orders of magnitude $( \pm 0.01, \pm 0.1$, and $\pm 1 \mathrm{~T})$, is available for calibrating demagnetization coils and measuring strong DC fields.

\section{Inorganic geochemistry}

\section{Interstitial water collection}

Interstitial water samples were obtained from 9 to $43 \mathrm{~cm}$ long whole-round sections from cores with $>1 \mathrm{~m}$ of recovery. These whole-round samples were cut and capped immediately after the core arrived on deck and then were scanned using X-ray CT. In general at each site, three whole rounds were collected from the first core and two whole rounds were collected per $9.5 \mathrm{~m}$ to the depth of the sulfate-methane transition (SMT). Below this depth, samples were collected at a frequency of one per $9.5 \mathrm{~m}$, if recovery was sufficient, with additional samples collected across lithologic and structural boundaries (i.e., deformed zones, splay faults, and the décollement). Within the gas hydrate stability zone, the entire core was scanned with an infrared (IR) camera to detect low-temperature anomalies, which are indicators of the potential occurrence of gas hydrates. When there was evidence of gas hydrate, an interstitial water whole-round sample was immediately cut from the core, taken to the QA/QC laboratory, and pushed out of the core liner, and if there was gas hydrate present, the pieces were stored in liquid nitrogen. If there was no visible hydrate, the section was cleaned thoroughly and squeezed. The differences in $\mathrm{Cl}$ concentration between the background profile and the 
hydrate section were used to compute the pore space gas hydrate occupancy.

Typical whole-round samples were immediately taken from the catwalk to the CT laboratory to be scanned for important lithologic boundaries and structures. The watchdog viewed the composite scan to determine if there were significant structures in the sample. The watchdog only rejected an interstitial water whole round if there was a clear structure unique to the core; otherwise, the sediment was taken to the QA/QC laboratory and immediately extruded from the core liner into a nitrogen-flushed glove bag. The exterior of the whole-round sample was then thoroughly cleaned of drilling contamination with a spatula, and the clean parts were placed into a Manheim-type titanium squeezer (Manheim, 1966) on top of two Millipore $18.2 \mathrm{M} \Omega \cdot \mathrm{cm}$ Type $1 \mathrm{ul}$ trapure (Milli-Q) water rinsed filter papers placed on two to four 320 mesh stainless steel screens. Two sizes of $\mathrm{Ti}$ squeezers were used during Expedition 316 ; one with an inner diameter of $5.5 \mathrm{~cm}$ and another with an inner diameter of $9 \mathrm{~cm}$. The sediments were squeezed at ambient temperatures and pressures of up to 20,000 $\mathrm{lb}$ for the small Ti squeezers and up to $32,000 \mathrm{lb}$ for the larger Ti squeezers to ensure that the interlayer water of clay minerals was not released during the squeezing process. This interstitial water was collected through the filters into a $60 \mathrm{~mL}$ acid-washed plastic syringe attached at the bottom of the squeezer assembly. After squeezing, the water was filtered through a $0.45 \mu \mathrm{m}$ disposable polytetrafluoroethylene (PTFE) filter into sample vials. Interstitial water aliquots were collected for shipboard analyses and will be supplemented by future shore-based analyses (Table T11). High-density polyethylene (HDPE) sample vials for minor and trace element analysis were cleaned by immersion in $55^{\circ} \mathrm{C} 10 \%$ trace metal grade $12 \mathrm{~N} \mathrm{HCl}$ for a minimum of $24 \mathrm{~h}$ and were subsequently rinsed in Milli-Q water and dried in a class 100 laminar flow clean hood. Samples for minor and trace element shipboard analysis were acidified with optima-grade $6 \mathrm{~N} \mathrm{HCl}$ at least $24 \mathrm{~h}$ prior to inductively coupled plasma-atomic emission spectroscopy (ICP-AES) or inductively coupled plasma-mass spectrometry (ICP-MS) analysis. Aliquots for shore-based isotopic, transition metals, and $U$ series analyses were stored in detergent- or acid-washed HDPE bottles. Additional aliquots for analyses of dissolved organic carbon and volatile fatty acids were placed in crimp-cap glass vials with $\mathrm{HgCl}_{2}$ and $\mathrm{HOSO}_{2} \mathrm{NH}_{2}$ and in precombusted glass vials (stored at $-20^{\circ} \mathrm{C}$ ), respectively. Samples for dissolved inorganic carbon were stored in crimpglass vials with $\mathrm{H}_{2} \mathrm{Cl}_{2}$ at room temperature. After pore fluid extraction was complete, the sediment squeeze cakes were immediately divided $\left(10-20 \mathrm{~cm}^{3}\right)$ and stored in vacuum-sealed plastic bags for shorebased analyses (Table T12). Sediment samples for shore-based microbiological and organic geochemical analyses were stored in a $-20^{\circ} \mathrm{C}$ freezer.

\section{Correction for drilling contamination}

In some intervals, the sedimentary material can be extremely fractured and brecciated (see "Inorganic geochemistry" in the "Expedition 316 Site C0004" chapter), making some interstitial water whole rounds extremely difficult to clean prior to processing. In these cases, even after being thoroughly cleaned, the interstitial water samples were still contaminated with fluid that was circulated in the borehole during drilling operations. This is not the case with cores collected using HPCS but does occur with cores collected using ESCS and RCB methods. In continental margin sediments, the SMT is generally reached at shallow depths in the sediment section, typically shallower than $\sim 40 \mathrm{~m}$. Below this depth, sulfate generally remains depleted. During Expedition 316, we cored using the HPCS through the SMT; ESCS and RCB coring were not used until much deeper in the sediment section. Thus, the presence of sulfate and methane in a sample collected below the SMT is a clear indication of drilling-induced contamination. For these cases, the $\mathrm{SO}_{4}$ concentration measured in the sample was used to estimate the amount of drill fluid introduced to the sample by taking the ratio of the sulfate measured in the sample to the $\mathrm{SO}_{4}$ concentration of surface seawater. The other analyses were corrected based on their concentration in surface seawater using the following equations:

$$
X_{\text {corrected }}=\left[X_{\text {measured }}-\left(f_{\mathrm{sw}} \times X_{\mathrm{sw}}\right)\right] / f_{\mathrm{pf}} \text {, }
$$

where

$X_{\text {measured }}=$ measured concentration of the analyte.

$X_{\mathrm{sw}} \quad=$ element concentration in surface seawater (used in drilling).

$X_{\text {corrected }}=$ corrected or in situ concentration of the analyte.

$f_{\mathrm{sw}} \quad=$ fraction of seawater introduced into the sample during drilling.

$f_{\mathrm{pf}} \quad=$ fraction of in situ pore fluid in the sample.

The fraction of seawater introduced by drilling and the fraction of in situ pore fluids are computed using Equations 21 and 22:

$$
f_{\mathrm{sw}}=\mathrm{SO}_{4 \text { measured }} / \mathrm{SO}_{4 \text { sw }}
$$

and 


$$
f_{\mathrm{pf}}=1-f_{\mathrm{sw}}
$$

We collected a sample of the drilling fluid used during coring operations and analyzed it for all of the species measured shipboard. When a sample contained sulfate above the ion chromatograph (IC) detection limit, the sulfate concentration of the drilling fluid was used to compute the amount of fluid added to the contaminated sample, which was then used to correct the other species analyzed. Both the measured and corrected pore fluid chemical concentration data are presented in the site chapters.

\section{Interstitial water analysis}

Interstitial water samples were routinely analyzed for $\mathrm{pH}$ and alkalinity by Gran titration with a $\mathrm{pH}$ electrode and a Metrohm autotitrator and for refractive index with a RX-5000 $\alpha$ refractometer (Atago) immediately after pore fluid extraction. The refractive index was converted to salinity based on repeated analyses of International Association of Physical Sciences of the Oceans (IAPSO) standard seawater. Precision for salinity was $<0.1 \%$ and the average precision for alkalinity analyses was $<2 \%$. The precision of the alkalinity titrations was monitored by repeated analysis of IAPSO standard seawater.

Sulfate and bromide concentrations were analyzed by ion chromatography (Dionex ICS-1500 IC) using subsamples that were diluted 1:100 with Milli-Q water. During squeezing, the first $4 \mathrm{~mL}$ of pore fluid was immediately transferred to a shipboard sample vial and analyzed for alkalinity. A $0.1 \mathrm{~mL}$ aliquot was taken from the vial and placed into a separate vial, and $20 \mu \mathrm{L}$ of $4 \mathrm{M}$ cadmium nitrate $\left(\mathrm{Cd}\left[\mathrm{NO}_{3}\right]_{2}\right)$ was added to precipitate the sulfide, thus leaving only sulfate in solution. The fixed samples were also diluted 100x with Milli-Q water. The nitrate in the fixed samples was used as an internal standard to increase the analytical precision of the sulfate analyses. Thus, two separate batches of analyses were run on the IC, one for dissolved $\mathrm{Br}$ concentration and a separate run for $\mathrm{SO}_{4}$ concentration. At the beginning and end of each run, several different dilutions of IAPSO standard seawater were analyzed as a quality control measure and to determine accuracy, and IAPSO standard seawater was analyzed after every seven samples as a check for instrumental drift and to calculate analytical precision. Precision for the bromide and sulfate analyses was $<3 \%$ and $<0.8 \%$, respectively. Average accuracy of bromide and sulfate was $<2 \%$ and $1.5 \%$, respectively.

Sulfate concentration was used as an indicator of drill water contamination of the interstitial water whole rounds. Below the SMT, sulfate is totally depleted and values should be below the detection limit of the IC method. Any sulfate measured in the interstitial water samples taken below the SMT is a clear indication of drilling fluid contamination.

Chlorinity was determined via titration with silver nitrate $\left(\mathrm{AgNO}_{3}\right)$. We used the convention "chlorinity" for the titration data because it yields not only dissolved chloride but also bromide and iodide. Because we analyzed bromide concentration shipboard by IC, the IC bromide concentration was subtracted from titrated chlorinity to compute true chloride concentration. Iodide was not measured shipboard during Expedition 316, but iodide concentration is generally low, within the error of the chloride data. In the site chapter geochemistry data tables, both the chlorinity data (from titration) and calculated chloride concentration (less IC bromide) are presented. The average precision of the chlorinity titrations, expressed as $1 \sigma$ standard deviation of means of multiple determinations of IAPSO standard seawater, is $\leq 0.2 \%$.

Dissolved ammonium concentration was measured within $24 \mathrm{~h}$ of collecting the interstitial water sample by colorimetry using an ultraviolet-visible (UVvis) spectrophotometer (Shimadzu UV-2550) at an absorbance of $640 \mathrm{~nm}$. A $0.1 \mathrm{~mL}$ sample aliquot was diluted with $1 \mathrm{~mL}$ of Milli-Q water, to which $0.5 \mathrm{~mL}$ phenol ethanol, $0.5 \mathrm{~mL}$ sodium nitroprusside, and $1 \mathrm{~mL}$ oxidizing solution (trisodium citrate and sodium hydroxide) were added in a capped plastic tube (Gieskes et al., 1991). The solution was kept in the dark at room temperature for $>3 \mathrm{~h}$ to develop color. Dissolved phosphate concentration was also measured by colorimetric method using the UV-vis spectrophotometer at an absorbance of $885 \mathrm{~nm}$. Because the phosphate concentration in the analysis solution must be $<10 \mu \mathrm{M}$, appropriate aliquots of sample or standard solution $(100$ or $600 \mu \mathrm{L})$ were diluted with $1.1 \mathrm{~mL}$ of Milli-Q water $(1000$ or $500 \mu \mathrm{L})$ in a plastic tube. The mixed solution (ammonium molybdate, sulfuric acid, ascorbic acid, and potassium antimonyl tartrate) was added to the tube (Gieskes et al., 1991), which was capped and kept at room temperature to develop color. Precision and accuracy of the ammonium analyses were $<2.5 \%$ and $3 \%$, respectively; precision and accuracy of the phosphate analyses were $<2 \%$ and $2 \%$, respectively.

Concentrations of major cations and minor elements (magnesium, calcium, sodium, potassium, strontium, lithium, iron, barium, silica, and boron) were analyzed by ICP-AES (Horiba Jobin Yvon Ultima2) designed for simultaneous analysis of sample elements and an internal standard. The major cations $(\mathrm{Mg}, \mathrm{Ca}, \mathrm{Na}$, and $\mathrm{K}$ ) were diluted by a factor of 501 by adding a $30 \mu \mathrm{L}$ aliquot of sample to $15 \mathrm{~mL}$ of $1 \%$ nitric acid (ultrapure double-distilled nitric 
acid solution) spiked with yttrium (10 ppm Y). Standardization of major cations was achieved by successive dilution of IAPSO standard seawater to $100 \%$, $75 \%, 50 \%$, and $25 \%$ relative to the $1: 501$ primary dilution ratio. Analytical precision based on repeated analyses of the $50 \%$ dilution standard is $\mathrm{Ca}<0.6 \%$, $\mathrm{Mg}<1.5 \%, \mathrm{Na}<2.5 \%$, and $\mathrm{K}<1.5 \%$. Average accuracies of the analyses based on repeated analyses of two unknowns (30\% and 60\% IAPSO standard seawater) were $\mathrm{Ca}<2 \%, \mathrm{Mg}<2 \%, \mathrm{Na}<4 \%$, and $\mathrm{K}<$ $2.5 \%$. Because of the poor precision and accuracy of the sodium determination, which is typical of $\mathrm{Na}$ analysis by ICP-AES, Na concentration was computed by charge balance, where

$$
\Sigma_{\text {(cation charge) }}=\Sigma_{\text {(anion charge) }} \text {. }
$$

$\mathrm{Na}$ concentration determined by charge balance as well as by ICP-AES is tabulated in each of the site chapters, but only sodium concentration calculated by charge balance is plotted in the figures.

To analyze the minor elements $(\mathrm{B}, \mathrm{Ba}, \mathrm{Fe}, \mathrm{Li}, \mathrm{Mn}, \mathrm{Si}$, and $\mathrm{Sr}$ ), the interstitial water sample aliquot was diluted by a factor of 20 ( $0.5 \mathrm{~mL}$ sample added to $9.5 \mathrm{~mL}$ of the same $10 \mathrm{ppm}$ Y solution described above). Because of the high concentration of matrix salts in the interstitial water samples at a 1:20 dilution, matrix matching of the calibration standards is necessary to achieve accurate results by ICP-AES. A matrix solution that approximated IAPSO standard seawater major ion concentrations was prepared from the following salts in $1 \mathrm{~L}$ of Milli-Q water acidified with $4 \mathrm{~mL}$ of optima-grade $6 \mathrm{~N} \mathrm{HCl}: 27 \mathrm{~g} \mathrm{NaCl}, 3.8 \mathrm{~g}$ $\mathrm{MgCl}, 1.0 \mathrm{~g} \mathrm{CaCO}_{3}$, and $0.75 \mathrm{~g} \mathrm{KCl}$. Sulfate was not added to the matrix-matching solution because pore fluid sulfate concentration decreased rapidly in the first few cores. Because the matrix solution was not a true blank, the procedural blank used was a dilution of the $1 \%$ nitric acid solution in the $\mathrm{Y}$ solution and only the slope of the calibration curve was used for quantification. A stock standard solution was prepared from ultrapure primary standards (SPC Science PlasmaCAL) in the $1 \%$ nitric acid solution. The relative concentrations of elements in the stock standard were adjusted based on results from Legs 131 and 190, as well as Expedition 315, during which samples were taken from sediments from similar formations. The stock solution was then diluted in the same $1 \%$ ultrapure nitric acid solution to concentrations of $50 \%, 25 \%, 10 \%, 5 \%$, and $1 \% .1 .25 \mathrm{~mL}$ of each stock solution was added to $8.75 \mathrm{~mL}$ of matrix solution to produce a series of standards that could be diluted using the same method as the samples for consistency. The final matrix-matched 100\% standard solution contained the following concentrations of elements: $\mathrm{B}=3000 \mu \mathrm{M}, \mathrm{Li}=400 \mu \mathrm{M}, \mathrm{Si}=1000 \mu \mathrm{M}$,
$\mathrm{Mn}=50 \mu \mathrm{M}, \mathrm{Fe}=50 \mu \mathrm{M}, \mathrm{Sr}=400 \mu \mathrm{M}$, and $\mathrm{Ba}=200 \mu \mathrm{M}$. Because values of many of these elements in IAPSO standard seawater are either below detection limits (e.g., Fe and $\mathrm{Mn}$ ) or variable, a standard prepared in the $10 \%$ matrix-matching solution was repeatedly analyzed to calculate the precision of the method. The average precision of the minor element analyses were $\mathrm{B}<1 \%$, $\mathrm{Ba}<1 \%$, Fe $<1.8 \%, \mathrm{Mn}<2 \%, \mathrm{Li}<1 \%$, $\mathrm{Si}<2 \%$, and $\mathrm{Sr}<1.5 \%$, and the average accuracy of the analyses were $\mathrm{B}<1.5 \%, \mathrm{Ba}<2 \%, \mathrm{Fe}<2 \%, \mathrm{Mn}<$ $2 \%, \mathrm{Li}<2 \%, \mathrm{Si}<3 \%$, and $\mathrm{Sr}<4 \%$.

Vanadium, copper, zinc, molybdenum, rubidium, cesium, lead, and uranium were analyzed by ICP-MS (Agilent 7500ce ICP-MS) equipped with an octopole reaction system to reduce polyatomic and doublecharge interferences. To calibrate for interferences by the major ions $\mathrm{Na}, \mathrm{Cl}, \mathrm{K}, \mathrm{Ca}$, and $\mathrm{S}$ on some of the transition metals $(\mathrm{ClO}$ and $\mathrm{SOH}$ on $\mathrm{V}, \mathrm{Na}$ and $\mathrm{CaOH}$ on $\mathrm{Cu}$, and $\mathrm{S}$ on $\mathrm{Zn}$ ), solutions were prepared containing these elements at concentrations similar to IAPSO standard seawater values. These solutions were analyzed at the beginning of each run, and an interference correlation was applied based on the average counts per second (cps) measured on the standard solutions divided by the abundance of the interfering elements. This ratio was multiplied by the known concentration of the major ions in the samples based on previous analysis, and the result was subtracted from the measured cps of the sample. A $100 \mu \mathrm{L}$ aliquot of $500 \mathrm{ppb}$ indium standard was added to the empty analysis vials before dilution. Sample aliquots were then diluted with the $1 \%$ nitric acid solution to $3 \%$ in these vials $(150 \mu \mathrm{L}$ sample with $4.85 \mathrm{~mL}$ of $1 \% \mathrm{HNO}_{3}$ solution) based on previous determination of the detection limits and low concentrations of the elements of interest. A primary standard solution was made that matched the maximum range of predicted concentrations based on published results of deep-sea pore fluid compositions in a variety of settings. The composition of the standard is as follows: $\mathrm{V}=20 \mathrm{ppb} ; \mathrm{Cu}, \mathrm{Mo}, \mathrm{Pb}$, and $\mathrm{U}=$ $40 \mathrm{ppb} ; \mathrm{Zn}=140 \mathrm{ppb} ; \mathrm{Rb}=500 \mathrm{ppb}$; and $\mathrm{Cs}=5 \mathrm{ppb}$. This primary standard was diluted in the $1 \%$ nitric acid solution to relative concentrations of $50 \%, 25 \%$, $10 \%, 5 \%$, and $1 \%$. These standards were then diluted to $3 \%$, similar to the standards, with the addition of $150 \mu \mathrm{L}$ of a $560 \mathrm{mM} \mathrm{NaCl}$ solution and $4.7 \mathrm{~mL}$ of the $1 \% \mathrm{HNO}_{3}$ solution to account for matrix suppression of the plasma ionization efficiency. The $25 \%$ standard was diluted accordingly and analyzed every eight samples throughout every analysis series for precision and in order to correlate the results from different analysis dates. Blanks were also analyzed every eight samples, and detection limits were determined as three times the standard deviation of a pro- 
cedural blank of Milli-Q water acidified with $4 \mathrm{~mL}$ of optima-grade $6 \mathrm{~N} \mathrm{HCl}$ per liter. The average precision of multiple determinations of the 10\% ICP-MS standard was $\mathrm{V}<6 \%, \mathrm{Cu}<14 \%, \mathrm{Zn}<3 \%$, Mo $<0.8 \%$, Rb $<0.7 \%$, Cs $<12 \%, \mathrm{~Pb}<3 \%$, and $\mathrm{U}<0.8 \%$.

\section{Shore-based analyses}

Because of the paucity of argon during the expedition, the analyses of the trace metals $(\mathrm{V}, \mathrm{Cu}, \mathrm{Zn}, \mathrm{Mo}$, $\mathrm{Rb}, \mathrm{Cs}, \mathrm{U}$, and $\mathrm{Pb}$ ) were suspended after Site C0006. Interstitial water samples from all sites were subsequently analyzed on shore for these trace metals on a Finnigan Element 2 high-resolution ICP-MS at Moss Landing Marine Laboratories (Moss Landing, California). There was no reference material available on the ship to verify the accuracy of the ICP-MS analyses. The accuracy of the shipboard analyses was determined by comparing the shore-based results for Sites C0004 and C0006 with the data generated during the expedition. In general, the shore-based and shipboard analyses agreed for $\mathrm{Cu}, \mathrm{Mo}, \mathrm{Pb}$, and $\mathrm{U}$. There were significant offsets between the analyses of $\mathrm{Rb}$ and $\mathrm{Cs}$ of $10 \%$ and $20 \%$, respectively. The shipboard $\mathrm{V}$ and $\mathrm{Zn}$ data were different from the shorebased data and standard reference material by a factor of 2, likely because of the poor quality of the shipboard standards. As a result of the large discrepancies between the data produced on shore and at sea, only the shore-based trace metal data are presented in this report. Yttrium was not determined during the expedition but was determined in the shore-based laboratory and is included in all of the data tables.

Shore-based ICP-MS analyses followed the methodology outlined in Hulme et al. (2008). Briefly, Rb, Mo, Cs, Y, U, and Pb concentrations were analyzed by dilution mass spectrometry. The samples were diluted to $1 \%$ in a solution of $10 \mathrm{~mL} / \mathrm{L}$ that was made from diluting subboiled, concentrated $(14.7 \mathrm{~N})$ nitric acid (optima grade) in Milli-Q water. Standard solutions were prepared from Claritas PPT standards in $1 \% \mathrm{HNO}_{3}$. The average percent error of the analyses ranged between $0.7 \%$ for $\mathrm{Rb}$ and $8.2 \%$ for $\mathrm{Mo}$. $\mathrm{V}, \mathrm{Cu}$, and $\mathrm{Zn}$ were determined by standard addition on $10 \%$ dilutions of three $200 \mu \mathrm{L}$ aliquots dissolved in $1 \% \mathrm{HNO}_{3}$. The accuracy of the standard addition analyses was determined by comparing the measured values of Pacific deep water for V (Wheat et al., 2002) and National Research Council of Canada (NASS-4) standard reference material for $\mathrm{Cu}$ and $\mathrm{Zn}$. The average precisions of the analyses are as follows: $\mathrm{V}<4 \%, \mathrm{Cu}<22 \%$, and $\mathrm{Zn}<18 \%$.

Interstitial water was also analyzed for stable isotopic composition of oxygen $\left(\delta^{18} \mathrm{O}\right)$ and hydrogen $(\mathrm{D} / \mathrm{H})$ on shore after the expedition. The $\delta^{18} \mathrm{O}$ and $\mathrm{D} / \mathrm{H}$ ratios were measured via a Delta Plus XP stable isotope mass spectrometer with a Gas Bench I (Thermo Finnigan), at New Energy Resources Research Center, Kitami Institute of Technology, Japan. The data are presented in per mil (\%) notation in reference to Vienna standard mean ocean water (VSMOW) with analytical precisions better than $0.5 \%$ for $\delta^{18} \mathrm{O}$ and $1 \%$ for $\mathrm{D} / \mathrm{H}$.

\section{Organic geochemistry}

The shipboard organic geochemistry program during Expedition 316 included analyses of volatile hydrocarbon content $\left(\mathrm{C}_{1}-\mathrm{C}_{4}\right)$, measurement of inorganic carbon and carbonate content of the sediments, and elemental analyses of total nitrogen, sulfur, and carbon. Procedures used during Expedition 316 follow Pimmel and Claypool (2001) and Shipboard Scientific Party (2003).

\section{Gas hydrates}

In order to identify the distribution of gas hydrates immediately upon recovery, a handheld IR camera (FLIR Systems ThermaCAM SC640) was used to scan the surface of the core to detect thermal anomalies caused by gas hydrate dissociation. Gas hydratebearing sections were immediately sampled and stored in liquid nitrogen bottles for further shorebased analyses.

\section{Gas analysis}

For safety and pollution prevention, concentrations and distributions of light hydrocarbon gases, mainly methane, ethane, and propane, were monitored for each core following standard headspace sampling. A $5 \mathrm{~cm}^{3}$ sediment sample was collected with a cut-off plastic syringe from the exposed end of Section 1 in each core. The sample was extruded into a $20 \mathrm{~mL}$ glass vial and immediately sealed with a septum and metal crimp cap. The vial was placed in an oven at $70^{\circ} \mathrm{C}$ for $30 \mathrm{~min}$. The monitoring procedure was complemented by additional headspace analyses following a slightly different approach with the intent to better constrain the concentrations of dissolved gases. Compared to the rapid safety-oriented protocol, the latter more time-consuming analyses led to higher yields of methane. Upon core retrieval, a $3 \mathrm{~cm}^{3}$ sediment sample was collected with a cut-off plastic syringe from a freshly exposed end of a core section and was extruded into a $20 \mathrm{~mL}$ glass serum vial containing $10 \mathrm{~mL}$ of $4 \% \mathrm{NaOH}$. The vial was immediately capped with a butyl septum and crimp cap. After shaking for 2 min using a tube mixer, the 
vials were subsequently left to stand for at least $24 \mathrm{~h}$ at room temperature prior to gas chromatographic analysis. When the sediments became too lithified, a cork borer was used to take the sample. Additionally, when gas pockets were observed, headspace samples were complemented by void gas samples, which were collected directly from gas voids by penetrating the core liner and using a gastight syringe. Gas chromatographic analyses of headspace samples resulting from both protocols were performed in an identical manner. The evolved $\mathrm{C}_{1}-\mathrm{C}_{4}$ gases were analyzed using an Agilent 6890N gas chromatograph (GC) equipped with a flame ionization detector (FID). Chromatographic response on the GC was calibrated against five different authentic standards with variable quantities of low molecular weight hydrocarbons. A $5 \mathrm{~mL}$ volume of headspace gas was extracted from the vial using a standard gas syringe and injected into the GC.

From the additional headspace analyses, the methane concentration in interstitial water was derived from the headspace concentration by the following equation where quantities of methane that remain undetected because dissolution in the aqueous phase is minimal (e.g., Duan et al., 1992) and are not accounted for:

$$
\mathrm{CH}_{4}=\left(\chi_{\mathrm{M}} \times P_{\mathrm{atm}} \times V_{\mathrm{H}}\right) /\left(\mathrm{R} \times T \times \varphi \times V_{\mathrm{S}}\right),
$$

where

$V_{\mathrm{H}}=$ volume of the sample vial headspace,

$V_{\mathrm{S}}=$ volume of the whole sediment sample,

$\chi_{M}=$ molar fraction of methane in the headspace gas (obtained from GC analysis),

$P_{\text {atm }}=$ pressure in the vial headspace (assumed to be the measured atmospheric pressure when the vials were sealed),

$\mathrm{R}=$ universal gas constant,

$T$ = temperature of the vial headspace in degrees Kelvin, and

$\varphi=$ sediment porosity (determined either from MAD measurements on nearby samples or from porosity estimates derived from GRA data representative of the sampled interval).

When heavier molecular weight hydrocarbons $\left(\mathrm{C}_{3}\right.$ and higher) were detected, gas samples were analyzed on the natural gas analyzer (NGA). The NGA system consists of an Agilent 6890N GC equipped with four different columns, two detectors, both an FID and a thermal conductivity detector (TCD), and WASSON.ECE instrumentation. The NGA was used to measure $\mathrm{C}_{1}-\mathrm{C}_{13}$ hydrocarbons and nonhydrocarbons $\left(\mathrm{CO}, \mathrm{CO}_{2}, \mathrm{O}_{2}\right.$, and $\left.\mathrm{N}_{2}\right)$. Gas samples collected from gas pockets were analyzed on the NGA.

\section{Inorganic carbon}

Inorganic carbon concentration was determined using a Coulometrics $5012 \mathrm{CO}_{2}$ coulometer. About 10$20 \mathrm{mg}$ of freeze-dried ground sediment was weighed and reacted with $2 \mathrm{M} \mathrm{HCl}$. The liberated $\mathrm{CO}_{2}$ was titrated, and the change in light transmittance was monitored with a photodetection cell. The weight percent of calcium carbonate was calculated from inorganic carbon content, assuming that all the evolved $\mathrm{CO}_{2}$ was derived from dissolution of calcium carbonate, by the following equation:

$\mathrm{CaCO}_{3}(\mathrm{wt} \%)=$ inorganic carbon $(\mathrm{wt} \%) \times 100 / 12$. $(25)$

No correction was made for the presence of other carbonate minerals. NIST-SRM 88b (Standard Reference Material) was used to confirm accuracy. Standard deviation for the samples was less than $\pm 0.1 \mathrm{wt} \%$.

\section{Elemental analysis}

Total carbon, nitrogen, and sulfur concentrations were determined using a Thermo Finnigan Flash EA 1112 CHNS analyzer with calibration using the synthetic standard sulfanilamide, which contains $\mathrm{C}$ (41.81 wt\%), N (16.27 wt \%), and S (18.62 wt\%). About 10-20 mg freeze-dried ground sediment was weighed and placed in a tin container for carbon and nitrogen analyses. For sulfur analysis, the same amount of freeze-dried sediment was weighed and put in a tin container with the same amount of $\mathrm{V}_{2} \mathrm{O}_{5}$ catalyst. Sediment samples were combusted at $1000^{\circ} \mathrm{C}$ in a stream of oxygen. Nitrogen oxides were reduced to $\mathrm{N}_{2}$, and the mixture of $\mathrm{CO}_{2}, \mathrm{~N}_{2}$, and $\mathrm{SO}_{2}$ was separated by gas chromatography and detected by TCD. Total organic carbon content was calculated by subtraction of inorganic carbon from total carbon. Standard deviation of carbon, nitrogen, and sulfur for the samples is less than $\pm 0.1 \%$. Accuracy for carbon and sulfur analysis was confirmed using two Geological Society of Japan (GSJ) reference samples.

\section{Microbiology and biogeochemistry}

Subseafloor environments represent the least explored habitats on Earth with regard to microbial life (D'Hondt et al., 2007). Enumeration of cell abundance by nucleic acid staining methods using acridine orange or SYBR Green I has shown that a large number of microbial cells are present in marine sediments to $\sim 800$ meters below seafloor (mbsf) (Parkes et al., 1994, 2000). The metabolic activity of deep microbes is extraordinarily low compared to those in seafloor sediments (D'Hondt et al., 2002, 2004). Nev- 
ertheless, this activity plays an important role in global biogeochemical cycling on the geological timescale. One of the subsurface interfaces that has attracted much attention in the past few years is that of the SMT zone where microbial activity is responsible for anaerobic oxidation of methane (e.g., Hinrichs et al., 1999; Parkes et al., 2005; Biddle et al., 2006; Inagaki et al., 2006a). Also, subseafloor microbes are thought to be responsible for methanogenesis, ethanogenesis, and propanogenesis (Hinrichs et al., 2006). Carbon isotopic fractionation through the activity of metabolic enzymes contributes to the accumulation of ${ }^{13} \mathrm{C}$-depleted hydrocarbons in the sediments. Microbial activity is controlled by the availability of electron donors and/ or acceptors, which are derived from either the surface via photosynthetic activities or geochemical activities in the underlying crust of the Earth (D'Hondt et al., 2004). Molecular phylogenetic analysis using $16 \mathrm{~S}$ ribosomal ribonucleic acid (rRNA) gene fragments indicates that subseafloor communities are highly diverse and are often composed of microbial strains lacking closely related cultivated relatives (Inagaki et al., 2003, 2006b). In addition, advanced molecular and lipid analyses suggest that the population of Archaea seems to be more abundant in subseafloor sediments than in the surface world (Lipp et al., 2008). Although the function of yet-uncultivated phylotypes remains largely unknown, significant extracellular enzymatic activities such as phosphatase and liparse have been detected in deep subseafloor sediments (Engelen et al., 2008; Kobayashi et al., 2008). The activity and habitability of life in the deep subseafloor biosphere is highly associated with geological settings in terms of carbon and energy flux.

Given this background, it is hypothesized that microbial abundance and activity are closely associated with energy and fluid flow regimes related to geological structures and plate movements. Expedition 316 provides an unprecedented opportunity to study the active subduction zone that directly connects to the deep seismogenic zone via the megasplay fault system. In addition, no systematic microbiological or biogeochemical studies have been conducted in deep subseafloor accretionary prisms. To understand such geosphere-biosphere interactions, multiple studies using microbiological, molecular biological, and biogeochemical approaches will be performed on shore using whole-round cores and subsampled materials.

\section{Whole-round cores}

\section{Core handling and sampling}

Because indigenous subsurface living microbes and their biomolecules such as deoxyribonucleic acid
(DNA), ribonucleic acid (RNA), intact polar lipids (IPLs), and enzymes are highly sensitive to oxygen, temperature, and exposure time, special attention to the processing of microbiology/biogeochemistry samples was required. After core was recovered in the core cutting area, sections were immediately stored in the refrigerator room adjacent to the QA/QC laboratory. Subsequently, X-ray CT scans were collected and the location of whole-round core sampling was determined according to the image, avoiding specific geological features such as lithologic boundaries and faults. Two types of whole-round cores $(7-20 \mathrm{~cm}$ in length) were sliced off in the QA/QC laboratory. The first type (frozen whole-round cores) were placed into plastic bags and stored at $-80^{\circ} \mathrm{C}$. These wholeround cores will be used for molecular (DNA and RNA) analyses as well as structure and carbon isotopic analysis of IPLs. The second type (anaerobically packed whole-round cores) were brought to an anaerobic glove box (Coy Laboratory Products, Inc.) in the microbiology laboratory, placed into an oxygenimpermeable vinyl bag with AnaeroPack (Mitsubishi Gas Chemical Co., Inc.), sealed with a plastic clip, and stored at $4^{\circ} \mathrm{C}$. End caps were placed on the whole-round core in the anaerobic glove box; otherwise even small amounts of oxygen ( 100 ppm) might contaminate the samples. The anaerobic whole-round core samples will be used for multiple biological studies (e.g., cultivation, activity measurements using radiotracers, and extracellular enzymes).

\section{Cell detection by fluorescent microscopy}

Fluorescent in situ hybridization (FISH) and catalyzed reporter deposition (CARD)-FISH techniques are powerful molecular ecological tools for visualization of specific living microbes that contain hybridizable 16S rRNA (Schippers et al., 2005). Because intracellular RNA is easily degraded by enzymatic reaction after cell death, it is necessary to fix the cells as soon as possible after core recovery. During Expedition $316,3 \mathrm{~cm}^{3}$ minicore samples were taken from the innermost part of the whole-round core in laminar-flow clean bench, fixed with $2 \%$ paraformaldehyde in phosphate-buffered saline (PBS, Invitrogen, $\mathrm{pH}$ adjusted to 7.6) for $10 \mathrm{~h}$ at $4^{\circ} \mathrm{C}$, washed twice with PBS, and stored in 3 times volume of PBS:ethanol $(1: 1)$ at $-20^{\circ} \mathrm{C}$. Centrifuge conditions for these washing steps were $9000 \times \mathrm{g}$ at $4^{\circ} \mathrm{C}$ for $10 \mathrm{~min}$. Alternatively, $50 \mathrm{~cm}^{3}$ of soft sediment was taken from the innermost whole-round core by tip-cut syringe, mixed with the same volume of acetone, vigorously shaken by hand for a few minutes, and stored at $-20^{\circ} \mathrm{C}$ (Fukatsu, 1999). The paraformaldehyde-fixed slurry samples were stained with SYBR Green I, which specifically binds double-stranded DNA and 
produces high fluorescent signals with low background (Lunau et al., 2005). Before staining, the fixed sediment slurry was vortexed and diluted 10 times with $10 \%$ (vol/vol) methanol in PBS. The mixture was sonicated at $40 \mathrm{~W}$ for 1 min with an ultrasonic homogenizer UH-50 (SMT Co., Ltd), and the sediment particles were removed by centrifuging at $100 \times \mathrm{g}$ for $2 \mathrm{~min}$ at $4^{\circ} \mathrm{C}$. A $5 \mu \mathrm{L}$ aliquot of the supernatant was mixed with $1 \mathrm{~mL}$ PBS and filtered through a black $0.2 \mu \mathrm{m}$ pore-sized polycarbonate filter. The filter was washed twice with $1 \mathrm{~mL}$ PBS, and the $1 / 8$ cut piece was placed on an object glass. A coverslip was mounted on the filter with $8 \mu \mathrm{L}$ of SYBR Green I staining solution (Lunau et al., 2005). Cells were viewed using an epifluorescence microscope (ZEISS Axioplan 2 imaging microscope), and images were taken with ZEISS AxioCam HRc camera and AxioVision AC software. Total cell abundance was enumerated by the average number of SYBR-stained particles in a microscopic field.

\section{Fractured pieces and rotary core barrel core sampling}

Because cores in the fault zone between 270 and $310 \mathrm{~m}$ CSF were highly fractured at Site C0004, we picked relatively large pieces $(>3 \mathrm{~cm}$ in diameter) from the interstitial water whole-round core section after the core surface trimming (see "Inorganic geochemistry"), washed the pieces four times with sterilized PBS ( $\mathrm{pH}$ 7.6) to remove potential contaminants from the seawater-based drilling mud, and crushed the pieces with a hammer in a sterilized aluminum bag. The PBS-washed powdered sediments were immediately stored at $-80^{\circ} \mathrm{C}$ with or without acetone or were anaerobically stored at $4^{\circ} \mathrm{C}$ in a glass bottle for cultivation and activity measurements. Bulk sediments without washing were obtained as control samples. Massive pieces of RCB cores were covered with a soft matrix that consists of drilling mud and cuttings. The core surface was washed with either sterilized PBS ( $\mathrm{pH}$ 7.6) or autoclaved Milli-Q water and processed as described above.

\section{Contamination test}

As it was not possible to do perfluorocarbon (PFC) tracer contamination tests shipboard, we monitored the infiltration of 0.5 and $1.0 \mu \mathrm{m}$ fluorescent microsphere beads according to the previously described protocol (Smith et al., 2000a, 2000b). As a control sample for contamination from drilling mud, freshly prepared drilling mud (seawater gel and kill mud) was obtained during Expedition 316 (Masui et al., 2008). Seawater gel is a seawater-based bentonite mud used for drilling and coring throughout the entire section. Seawater gel $(\mathrm{pH}$ 12.3) contains $0.5 \mathrm{~m}^{3}$ seawater, $0.5 \mathrm{~m}^{3}$ drill water, $60.0 \mathrm{~kg}$ bentonite, $2.0 \mathrm{~kg}$ caustic soda, and $2.0 \mathrm{~kg}$ lime. Kill mud is a freshwater-based barite-weighted mud used to suspend or abandon the hole. It was not used before or during Expedition 316 coring. Kill mud ( $\mathrm{pH}$ 11.3) contains $1 \mathrm{~m}^{3}$ drill water, $60.0 \mathrm{~kg}$ bentonite, $1.0 \mathrm{~kg}$ caustic soda, $2.0 \mathrm{~kg}$ polyanionic cellulose derivatives, and $40.0 \mathrm{~kg}$ barite. The density of both drilling muds is $1.05 \mathrm{~g} / \mathrm{cm}^{3}$. The subsamples for culturing and molecular analysis were stored at $4^{\circ} \mathrm{C}$ and $-80^{\circ} \mathrm{C}$, respectively. Natural chemical tracers such as sulfate in pore water will be carefully checked, especially for highly fractured core samples.

\section{Physical properties}

Physical property measurements provide fundamental information required to characterize lithologic units and allow for the correlation of coring results with downhole logging data. A variety of techniques and methods were used to characterize Expedition 316 core samples. Prior to sampling and interpretation, X-ray CT images were captured for all cores. After the CT scans were completed, GRA density, magnetic susceptibility, natural gamma radiation, $P$-wave velocity, and electrical resistivity were measured using the MSCL-W after thermal equilibriation at room temperature $\left(\sim 20^{\circ} \mathrm{C}\right)$. Moisture and density were determined for discrete samples collected from working halves, using a custom built BAL-2 motioncompensated shipboard balance system and a Quantachrome penta-pycnometer. The shear strength of sediments in the working halves was measured using a Wykeham Farrance WF23500 vane shear device and a Geotest E-284b penetrometer. For cores with unlithified sediments, thermal conductivity measurements were carried out on whole-round core sections using a Teka (Berlin, Germany) thermal conductivity meter with the VLQ full-space needle probe following MSCL measurements. However, if the sediments were lithified such that a needle probe could not be inserted or good contact between the core material and the needle probe could not be made, thermal conductivity measurements were made on split working halves using the Teka thermal conductivity meter in half-space mode. At Site C0004, a Kyoto Electronics QTM-500 thermal conductivity meter was used for half-space measurements. Digital image scanning and color spectrophotometry were carried out on the cut surfaces of archive halves using the photo image capture logger (MSCL-I) and color spectrophotometer (MSCL-C), respectively. Details about each physical property measurement are described below. 


\section{MSCL-W}

\section{Gamma ray attenuation density}

The gamma ray detector comprises a scintillator and an integral photomultiplier tube. A gamma ray beam produced by a ${ }^{137} \mathrm{Cs}$ gamma ray source at a radiation level of $370 \mathrm{MBq}$ within a lead shield with a $5 \mathrm{~mm}$ collimator is directed through whole-round cores. Bulk density, $\rho$, determined with this method can be expressed as follows:

$$
\rho=(\mu d)^{-1} \times \ln \left(I_{0} / I\right)
$$

where

$$
\begin{aligned}
\mu & =\text { Compton attenuation coefficient } \\
d & =\text { sample diameter } \\
I_{0}= & \text { gamma ray source intensity, and } \\
I= & \text { measured intensity of gamma rays passing } \\
& \text { through the sample. }
\end{aligned}
$$

Because $\mu$ and $I_{0}$ are treated as constants, $\rho$ can be calculated from $I$. The gamma ray detector is calibrated with a set of aligned aluminum cylinders of various diameters, surrounded by distilled water in a sealed core liner used for drilling. Gamma ray counts through each cylinder are determined for a period of $60 \mathrm{~s}$, and the resulting intensities are plotted as $\ln (I)$ versus $\mu d$. Here $\rho$ of each aluminum cylinder was $2.7 \mathrm{~g} / \mathrm{cm}^{3}$, and $d$ was $1,2,3,4,5$, or $6 \mathrm{~cm}$. The relationship between $I$ and $\mu d$ can be expressed as follows:

$$
\ln (I)=A(\mu d)^{2}+B(\mu d)+C,
$$

where $A, B$, and $C$ are coefficients determined during calibration. These coefficients fluctuated slightly during the time period over which the measurements were made, as indicated by repeat calibrations over time. The MSCL provided the values of $I$ and $\mu$, and $\rho$ was calculated with Equation 26. Density measurements on the core samples were conducted every $4 \mathrm{~cm}$ for $4 \mathrm{~s}$. The spatial resolution was $5 \mathrm{~mm}$, so each data point reflects the properties of the nearest $5 \mathrm{~mm}$ interval.

\section{Magnetic susceptibility}

Magnetic susceptibility is the degree to which a material can be magnetized by an external magnetic field. A Bartington loop sensor (MS2C) with an $8 \mathrm{~cm}$ loop diameter was used to measure magnetic susceptibility. An oscillator circuit in the sensor produces a low-intensity ( $\sim 80 \mathrm{~A} / \mathrm{m} \mathrm{RMS})$, nonsaturating, alternating magnetic field $(0.565 \mathrm{kHz})$. Any material near the sensor that has a magnetic susceptibility causes a change in the oscillator frequency. This pulse frequency is then converted into magnetic susceptibility values. The spatial resolution of the loop sensor is
$23-27 \mathrm{~mm}$, and it is accurate to within $2 \%$. Like the GRA density data, magnetic susceptibility data were obtained at $4 \mathrm{~cm}$ intervals with a $4 \mathrm{~s}$ acquisition time.

\section{Natural gamma ray}

Natural gamma ray (NGR) emissions were recorded from all core sections to determine variations in the radioactive counts of the samples and for correlation with downhole NGR measurements. A lead-shielded counter, optically coupled to a photomultiplier tube and connected to a bias base that supplied the highvoltage power and a signal preamplifier, is used. Two horizontal and two vertical sensors are mounted in a lead cube-shaped housing. The NGR system records radioactive decays of ${ }^{40} \mathrm{~K},{ }^{232} \mathrm{Th}$, and ${ }^{238} \mathrm{U}$, which are three long-period isotopes that decay at an essentially constant rate within measurable timescales. Spatial resolution for Expedition 316 samples was 120-170 mm, and NGR was measured every $20 \mathrm{~cm}$ for $30 \mathrm{~s}$. Background radiation noise was $38 \mathrm{cps}$, measured by inserting a blank filled with quartz powder into the instrument.

\section{$\boldsymbol{P}$-wave velocity}

The basic relationship for sonic velocity, $V$, is

$$
V=d / t
$$

where

$$
\begin{aligned}
& d=\text { path length of the wave across the core diame- } \\
& \text { ter, and }
\end{aligned}
$$$$
t=\text { traveltime through the core. }
$$

$P$-wave velocity transducers are mounted on the MSCL system and $t$ is measured horizontally across the whole core diameter. Total traveltime between the transducers includes three components:

$$
\begin{aligned}
t_{\text {delay }}= & \text { time delay related to transducer faces and } \\
& \text { electronic circuitry, } \\
t_{\text {pulse }}= & \text { delay related to the peak detection proce- } \\
& \text { dure, and } \\
t_{\text {liner }}= & \text { transit time through the core liner. }
\end{aligned}
$$

The system is calibrated using a core liner filled with pure water. For routine measurements on wholeround cores in core liners, the corrected core velocity, $V_{\text {core }}$, can be expressed by

$$
V_{\text {core }}=\left(d_{\text {core }}^{\prime}-2 d_{\text {liner }}\right) /\left(t_{0}-t_{\text {pulse }}-t_{\text {delay }}-2 t_{\text {liner }}\right) \text {, }
$$

where

$$
\begin{aligned}
& d_{\text {core }}^{\prime}=\text { measured diameter of core and liner, } \\
& d_{\text {liner }}=\text { liner wall thickness, and } \\
& t_{0} \quad=\text { measured total traveltime. }
\end{aligned}
$$




\section{Electrical resistivity}

The bulk electrical resistivity, $\Phi_{\mathrm{b}}$, of a core of length, $L$, and cross section area, $S$, at constant temperature can be expressed as

$$
\Phi_{\mathrm{b}}=R(S / L),
$$

where $R$ is electrical resistance. The effect of pore fluid on bulk resistivity depends critically on whether the fluid-filled pores are connected in a through-going network or are isolated. The bulk electrical resistivity of a fluid-filled sediment relative to that of the pore fluid is described by an apparent formation factor, $F_{\mathrm{a}}$ (Archie, 1947),

$$
F_{\mathrm{a}}=\Phi_{\mathrm{b}} / \Phi_{\mathrm{w}}
$$

where $\Phi_{\mathrm{w}}$ is the resistivity of the pore fluid. Values of $F_{\mathrm{a}}$ include the effect of grain-surface conductivity and thus do not represent the true formation factor, $F=\tau^{2} / \phi_{c}$, where $\tau$ is the true tortuosity of the fluid flow path and $\phi_{c}$ is the connected porosity.

The noncontact resistivity sensor on the MSCL system operates by inducing a high-frequency magnetic field in the core with a transmitter coil. This induces an electrical current in the core that is inversely proportional to its resistivity. The secondary magnetic field generated by this induced electrical current is measured by a receiver coil. To measure this smaller magnetic field accurately, a differencing technique has been developed that compares readings from the sample core to readings from an identical set of coils operating in air. Electrical resistivity data were obtained at $4 \mathrm{~cm}$ intervals.

\section{Moisture and density measurements}

Index properties (bulk density, grain density, water content, porosity, and dry density) of core samples were calculated from measurements of wet and dry weights and dry volumes on discrete samples from the working half of the split core. Approximately $10 \mathrm{~cm}^{3}$ of material was sampled from two intervals (conventionally at 24 and $100 \mathrm{~cm}$ ) for each workinghalf section. In addition, MAD samples were routinely taken from the "cluster" slices adjacent to whole-round samples. If the whole-round sampling location overlapped the regular MAD sampling intervals, no additional sample was taken.

Wet and dry masses were measured using a paired electronic balance system, which is designed to compensate for the ship's heave. The sample mass was counterbalanced with a precisely known mass (usually $10 \mathrm{~g}$ ) that was within $5 \mathrm{~g}$ of the sample mass. The sample mass was determined to a precision of $\pm 0.01 \mathrm{~g}$. The balance system was calibrated at each drill site.

Immediately after the samples were collected, wet sediment mass $\left(M_{\text {wet }}\right)$ was measured. Care was taken to sample undisturbed parts of the core and to avoid drilling mud. Dry sediment mass $\left(M_{\text {dry }}\right)$ and volume $\left(V_{\text {dry }}\right)$ were measured after drying the samples in a convection oven for $>24 \mathrm{~h}$ at $105^{\circ} \pm 5^{\circ} \mathrm{C}$. Dried samples were then cooled in a desiccator for $>1 \mathrm{~h}$ before the dry mass was measured. Dry volume was measured using a helium-displacement pycnometer with a nominal precision of $\pm 0.04 \mathrm{~cm}^{3}$. Each reported value consists of an average of three measurements. A reference volume (calibrated sphere) was run with each group of four samples, and the sphere was rotated between cells to check for systematic error.

For calculation of bulk density, dry density, grain density, porosity, and void ratio, the traditional ODP method is used ("Method C;" Blum, 1997). Water content, porosity, and void ratio are defined by the mass or volume of extracted water before and after removal of interstitial pore water through the drying process. Standard seawater density $\left(1.024 \mathrm{~g} / \mathrm{cm}^{3}\right)$ was assumed for the density of pore water.

\section{Water content}

Water content, $W_{c}$, was determined following the methods of the American Society for Testing and Materials (ASTM) designation D2216 (ASTM, 1990). Corrections are required for salt when measuring the water content of marine samples. In addition to the recommended water content calculation in ASTM D2216 (i.e., the ratio of pore fluid mass to dry sediment mass [percent dry weight]), we also calculated the ratio of pore fluid mass to total sample mass (percent wet weight). The equations for water content are:

$$
W_{\mathrm{c}}(\% \text { dry wt })=\left(M_{\mathrm{t}}-M_{\mathrm{d}}\right) /\left(M_{\mathrm{d}}-r M_{\mathrm{t}}\right)
$$

and

$$
W_{\mathrm{c}}(\% \text { wet wt })=\left(M_{\mathrm{t}}-M_{\mathrm{d}}\right) \times(1+r) / M_{\mathrm{t}} \text {, }
$$

where

$$
\begin{aligned}
& M_{\mathrm{t}}=\text { total mass of the saturated sample, } \\
& M_{\mathrm{d}}=\text { mass of the dried sample, and } \\
& r \quad=\text { permil salinity. }
\end{aligned}
$$

\section{Bulk density}

Bulk density, $\rho$, is the density of the saturated samples with $\rho=M_{\mathrm{t}} / V_{\mathrm{t}}$. Mass, $M_{\mathrm{t}}$, was measured using the balance, and $V_{\mathrm{t}}$ was determined from the pycnome- 
ter measurements of grain volume and the calculated volume of the pore fluid $\left(V_{\mathrm{t}}=V_{\text {pore }}+V_{\mathrm{d}}\right)$.

\section{Porosity}

Porosity, $\phi$, was calculated using

$$
\phi=\left(W_{\mathrm{c}} \times \rho\right) /\left[\left(1+W_{\mathrm{c}}\right) \times \rho_{\mathrm{w}}\right],
$$

where

$\rho=$ measured bulk density,

$\rho_{\mathrm{w}}=$ density of the pore fluid, and

$W_{\mathrm{c}}=$ water content expressed as a decimal ratio of percent dry weight.

\section{Grain density}

Grain density, $\rho_{\text {grain, }}$ was determined from measurements of dry mass and dry volume made in the balance and in the pycnometer, respectively. Mass and volume were corrected for salt using

$$
\rho_{\text {grain }}=\left(M_{\mathrm{d}}-s\right) /\left[V_{\mathrm{d}}-\left(s / \rho_{\text {salt }}\right)\right],
$$

where

$$
s=\text { salt content (in grams) and }
$$$$
\rho_{\text {salt }}=\text { density of salt }\left(2.257 \mathrm{~g} / \mathrm{cm}^{3}\right) \text {. }
$$

\section{Shear strength measurements}

The shear strength of sediments in the working half of the core was measured using an analog semiautomated laboratory vane shear device (Wykeham Farrance, model WF23544) and a pocket penetrometer (Geotest Instrument Co., model E-284B). Measurements were made at discrete locations on the working halves at a frequency of approximately three per core and, where possible, adjacent to MAD sampling horizons. Care was taken to conduct tests within undisturbed and homogeneous parts of the core. To minimize disturbance effects resulting from the measurement itself, vane shear tests were generally conducted first, followed by penetrometer tests, and then MAD sampling. Measurements were made with the vane rotation axis and the penetrometer penetration direction perpendicular to the flat face of the split core.

Vane shear strength, $S_{\mathrm{u}(\mathrm{v})}$, can be expressed as

$$
S_{\mathrm{u}(v)}=T / \mathrm{K}_{\mathrm{v}}
$$

where

$T=$ torque in $\mathrm{N} \cdot \mathrm{m}$ required to cause failure in the material, and

$\mathrm{K}_{\mathrm{v}}=$ constant with units of volume with magnitude dependent on the dimensions of the vane (Blum, 1997).
All measurements were obtained using a vane with a height of $12.7 \mathrm{~mm}$ and a blade length of $6.35 \mathrm{~mm}$. Failure torque was determined by measuring the rotation of one of four torsional springs and applying linear calibration equations (manufacturer specified) relating rotation angle to torque for each spring. Selection of the appropriate spring was based on the anticipated shear strength of the material. Vane shear strength results were generally considered reliable for shear strength values less than $~ 150-200$ $\mathrm{kPa}$, above which excessive cracking and separation of the core material occurred.

The pocket penetrometer provides a measure of unconfined compressive strength $\left(q_{\mathrm{u}}\right)$ in units of kilograms per square centimeter. Compressive strength is calculated from the penetration resistance generated by pushing a cylindrical probe $6.4 \mathrm{~mm}$ into the split core surface (Blum, 1997). Penetrometer-based shear strength $\left(S_{\mathrm{u}(\mathrm{p})}\right)$ is calculated as measured compressive strength converted to units of kilopascals and divided by two. Reported shear strength values were calculated from the average of three penetration tests conducted at adjacent points on the core. The typical spatial separation between tests was $\sim 1 \mathrm{~cm}$. All measurements were obtained using a flat surface probe with a nominal diameter of $6.4 \mathrm{~mm}$.

\section{Anisotropy of electrical conductivity and $P$-wave velocity}

Electrical conductivity and $P$-wave velocity measurements were performed on $\sim 20 \mathrm{~mm} \times 20 \mathrm{~mm} \times 20$ $\mathrm{mm}$ samples cut from RCB cores with a diamond blade saw. This sample preparation enables first order measurement of both electrical conductivity and $P$-wave velocity anisotropies. All cubes were cut with faces 1,2 , and 3 orthogonal to the $x-, y$-, and $z$-axes of the core reference, respectively. Orientation of the axes was the same as the convention for paleomagnetism, with $z$ pointing down along the core axis, $x$ pointing into the working half, and $y$ perpendicular to $z$ within the core face.

To measure electrical conductivity, the sample was held between two stainless steel electrodes covered with filters soaked in seawater. The complex impedance $(R+j X)$ was measured at $10 \mathrm{kHz}$ between opposite cube faces with an Agilent 4263B component analyzer. Three such measurements were performed along directions $x, y$, and $z$. The conductance tensor component (e.g., $\sigma_{x}$ ) along a given direction (e.g., $x$ ) was computed from the impedance measured along this direction and sample dimensions according to the formula

$$
\sigma_{\mathrm{x}}=\frac{L_{\mathrm{x}}}{L_{\mathrm{y}} L_{\mathrm{z}}}\left(\frac{\left(R_{\mathrm{x}}-R_{0}\right)-j\left(X_{\mathrm{x}}-X_{0}\right)}{\left(R_{\mathrm{x}}-R_{0}\right)^{2}+\left(X_{\mathrm{x}}-X_{0}\right)^{2}}\right),
$$


where $L$ is the length and $R_{0}$ and $X_{0}$ refer to the measured impedance of the filter. Conductance tensor components $\sigma_{y}$ and $\sigma_{z}$ were obtained by substitution in this formula.

To measure $P$-wave velocity along a given direction, the sample was held with a force of $49 \mathrm{~N}$ (corresponding to a pressure of $120 \mathrm{kPa}$ ) between two transducers (large-bandwidth transducers with a central working frequency at $500 \mathrm{MHz}$ ) covered with rubber spacers. The transmitter was connected to a pulse generator (Physical Acoustics C-101-HV), and the receiver was connected to an oscilloscope synchronized with the pulse generator. The oscilloscope signal was transferred to a computer, and the arrival time was picked and logged automatically. This configuration had a characteristic delay of $2.10 \mu \mathrm{s}$, which was subtracted from the arrival time to obtain the traveltime. The velocity along a given direction is simply given by the path length divided by the traveltime.

When only three measurements are made, the orientation of the tensor cannot be determined. However, some simplifications may be expected if the sample is almost transversely isotropic around the core axis. The apparent anisotropy in the horizontal plane is

$$
a_{1} \%=200 \frac{\left|\sigma_{x}-\sigma_{y}\right|}{\sigma_{x}+\sigma_{y}} .
$$

Apparent transverse anisotropy is

$$
a_{\mathrm{T}} \%=200\left(\frac{\sigma_{\mathrm{x}}+\sigma_{\mathrm{y}}}{2}-\sigma_{\mathrm{z}}\right) /\left(\frac{\sigma_{\mathrm{x}}+\sigma_{\mathrm{y}}}{2}+\sigma_{\mathrm{z}}\right) .
$$

For a truly transversely anisotropic medium in the core reference frame $(x, y$, and $z)$, the anisotropy ratio $\alpha=a_{1} / a_{\mathrm{T}}$ is a function of the dip of the foliation in the sample. Plotting the anisotropy ratio as a function of dip for a collection of samples within the same interval can resolve the ambiguity between a dipping transversely anisotropic medium and a fully anisotropic one.

At Site C0006, measurements in more directions that the three orthogonal ones described above were made by cutting off the eight corners of the cube at a bisecting angle to $x, y$, and $z$, providing a total of seven measurements. From these values, a best fitting ellipsoidal function (which requires a minimum of six measurements in different directions) was calculated following the method of Louis et al. (2004). Such an analysis can provide both anisotropy values and 3-D principal directions of the dominant microstructural feature (preferential alignment of matrix components, crack network, solution cleavage surfaces, etc.).

Apart from an instrumental uncertainty on the order of $1 \%$, an important issue prior to interpreting electrical conductivity and $P$-wave velocity data is the effect of decreasing sample saturation prior to measurement. Electrical conductivity is strongly sensitive to the saturation of the pore network, and $P$-wave velocity is sensitive to water content through changes in the incompressibility modulus $(K)$. The effects of decreasing saturation on electrical conductivity were not analyzed because this measurement was typically performed immediately after sawing the sample into a cube. However, in order to compensate for the effect of partial drying of the sample during the measurement, the first impedance value obtained across the sample was remeasured after impedances in the other two orientations were recorded.

$P$-wave velocity values are more likely to be affected by partial drying because of the time needed to cut the cubes into polyhedrons. We investigated the effect of drying on a cubic sample left at ambient laboratory conditions (average over the test of $20.4^{\circ} \mathrm{C}$ and $32.5 \%$ relative humidity). Traveltimes were measured along the three directions every $30 \mathrm{~min}$ until a stable level was reached (Fig. F28). The evolution of $P$-wave velocity with time is clearly nonlinear and indicates a considerable decrease of $>20 \%$ over the first $2 \mathrm{~h}$. This effect has the potential to exert a strong bias on the final velocity-depth profile and tensor. Moreover, further testing showed that, at least for some of the samples measured at Site C0006, this decrease in $P$-wave velocity could not be recovered through resaturation with seawater. After the tested sample had been immersed for $<2 \mathrm{~min}$ in a beaker filled with seawater, we observed an increase of $10 \%$ in $P$-wave traveltime. This effect could be due to a loss of overall material cohesion associated with clay swelling or to dissolution of newly crystallized sodium chloride near the sample surface or within pore throats. We estimated the uncertainty associated with the drying process as a function of the typical time between the cutting operation and $P$-wave velocity measurement. Figure F28 suggests that an uncertainty of $-0.2 \mathrm{~km} / \mathrm{s}$ appears appropriate for a duration of up to $1 \mathrm{~h}$ for the full measurement process.

\section{Thermal conductivity}

Thermal conductivity was measured on unconsolidated sediment and rock samples using either the full-space needle probe (Von Herzen and Maxwell, 1959) or the half-space line source (Vacquier, 1985), depending on the consolidation state of the material being measured. Both the full- and half-space methods approximate the heating element as an infinite line source (Blum, 1997). These measurements produce a scalar value in a plane perpendicular to the orientation of the probe. All measurements were 
made after the cores had equilibrated to ambient laboratory temperature. At the beginning of each measurement, temperature in the samples was monitored to ensure that the background thermal drift was $<0.04^{\circ} \mathrm{C} / \mathrm{min}$. After the background thermal drift was determined to be stable, the heater circuit was closed and the increase in the probe temperature was recorded. In most cases the reported thermal conductivity value for full-space needle probe measurements is the average of at least three repeated measurements. For half-space line source thermal conductivity, values typically represent the average of between five and ten repeated measurements. Based on repeated measurements, individual measurements are usually within $1 \%$ of the mean for both full- and half-space measurements. Both of these values are within the stated uncertainty of $5 \%$ (Blum, 1997). All data are corrected to in situ pressure and temperature, assuming a hydrostatic pressure gradient and a background temperature gradient based on advanced piston coring temperature tool (APCT3) and Davis-Villinger Temperature Probe (DVTP) or sediment temperature (SET) tool measurements. The pressure correction is $+1 \%$ for each 1800 mbsf (Ratcliffe, 1960). In porous rocks, temperature influences thermal conductivity in two competing ways. The thermal conductivity of rock matrix is inversely related to temperature (Zoth and Haenel, 1988), whereas the thermal conductivity of water increases with temperature (Keenan et al., 1978). We applied a temperature correction of $+1 \%$ for each $+20^{\circ} \mathrm{C}$ change in temperature between laboratory and in situ conditions, a value intermediate between $+5 \%$ suggested by Ratcliffe (1960) for a high-porosity water-saturated sediment and mean value of $-3 \%$ derived from data reported by Clark (1966) for several hard rocks. Both uncorrected and corrected values of thermal conductivity are reported.

Unfortunately, many sites had sections of core where neither the full-space nor half-space method was appropriate. These sections are typified by consolidated material that was either loose or cracked when the needle probe was inserted such that good contact between core material and the needle probe was not possible or the material was so consolidated that the needle probe could not be inserted. Although these sections were consolidated, they also lacked pieces large enough for the half-space method. Divided bar measurements are planned postcruise to fill in these intervals. Importantly though, these intervals were below the depths of temperature measurements so that the lack of thermal conductivity measurements does not affect the determination of heat flow. They do, however, affect the confidence with which temperature can be extrapolated to depth.

\section{Soft-sediment full-space measurements}

A full-space single-needle probe TeKa TK04 unit (Blum, 1997) was utilized to measure thermal conductivity of HPCS whole cores. To insert this probe, a $2 \mathrm{~mm}$ hole was made in the core liner at a position based on visual inspection of the core supplemented in some cases with CT scans. Needle probes consist of a heater wire and a thermistor. At the beginning of each measurement, temperature in the sediment was monitored to ensure that a thermal drift of no more than $0.4 \mathrm{mK} / \mathrm{min}$ was present. This step normally took 1-2 min. After the temperature field was determined to be near equilibrium, a calibrated heat source was applied and the rise in temperature was recorded for $\sim 80 \mathrm{~s}$. Values of thermal conductivity were based on the observed rise in temperature for a given quantity of heat. In most cases, repeated measurements were made at the same location and the needle probe was left in place to reequilibrate for 10 min prior to the next measurement. Thus, most of the measurement time consisted of waiting for the sample to reequilibrate.

Between holes or when time permitted, the needle probe was calibrated using three standards with thermal conductivities of 0.517 (rubber), 1.237 (glass), and $1.623 \mathrm{~W} /(\mathrm{m} \cdot \mathrm{K})$ (Fig. F29A). These measurements were plotted against true values, and the slope of the linear regression gave constants that were used to calibrate the needle probe (Table T13).

With increasing depths, sediments became more consolidated such that it was not possible to simply insert the needle probe into the core without damaging the probe. In these cases, a half-space line source was used to measure thermal conductivity.

\section{Lithified sediment and hard rock half-space measurements}

Increased consolidation of core sediments with depth required thermal conductivity measurements to be conducted on split core halves instead of on whole-round samples. At Site C0004, a Kyoto Electronics QTM-500 quick thermal conductivity meter was utilized for thermal conductivity measurements on lithified samples, and for later sites, the TK04 device was used in half-space mode. Selected samples taken from split-core working halves were relatively intact and at least $8 \mathrm{~cm}$ long. Samples were placed in a seawater bath for at least $15 \mathrm{~min}$. For the QTM-500 device, samples were placed in plastic wrap to protect the line source. Care was taken to remove any visible air bubbles between the plastic wrap and the sample surface. The heating element/temperature probe was then placed on a flat surface of the sample, and heating and temperature measurements were conducted by the instrument. Between mea- 
surements, the sample was allowed to cool for at least $10 \mathrm{~min}$. For measurements made with the QTM-500, each reported value consists of an average of three measurements, whereas measurements made with the TeKa device report values consisting of 5-10 measurements. Calibration procedures for this half-space heating technique are similar to those for the needle probe technique used on whole-round samples. For the TeKa device, calibrations were made using four standards with thermal conductivities of 0.517 (rubber), 1.237 (glass), 1.414, and $1.623 \mathrm{~W} /$ $(\mathrm{m} \cdot \mathrm{K})$ (Fig. F29B), whereas for the QTM-500 only three standards were used (Fig. F29C). These measurements are plotted against the true values and calibrations constants determined through a leastsquares inversion (Table T13).

\section{In situ temperature measurements}

In situ temperature measurements were made using the APCT3, DVTP, and SET tool. The APCT3 is the third-generation tool of its kind and is used with the HPCS. The APCT3 consists of three components: electronics, coring hardware, and computer software. The SET tool was developed by IODP, based on the DVTP design used during ODP and early IODP expeditions. Improved electronics and packaging provides high-resolution temperature measurements. The SET tool was used to take temperature measurements in stiffer formations during Expedition 316. During Expedition 316, in situ temperature measurements were made for approximately every third core during HPCS coring. The temperature sensors were calibrated for a working range of $0^{\circ}-45^{\circ} \mathrm{C}$.

Prior to entering the hole, each instrument was held at the approximate mudline for $\sim 5 \mathrm{~min}$ to equilibrate with bottom water temperature. However, the core winch depth meter was not calibrated, and site variability in measured bottom water temperature is likely due to uncertainties in depth. After bottom water temperature equilibration, the tools were lowered down the hole and penetrated the formation. The penetration of each tool into the formation causes a rise in temperature because of frictional heating. Following the initial rise in temperature, temperature decreases along a decay curve to near equilibrium. During this decay phase, it is important that the temperature tool is not disturbed. A second rise in temperature is due to frictional heating as the tool is pulled out of the formation. Temperature was measured as a time series sampled every $1 \mathrm{~s}$ and logged onto a microprocessor within the downhole tool; when the tool was retrieved, data were downloaded to the computer. The formation equilibrium temperature is determined based on fitting the temperature decay curve using the program TP-Fit, which runs on Matlab (M. Heeseman, pers. comm., 2007).

\section{Determination of heat flow}

If heat transfer is by conduction and heat flow is constant, the thermal gradient will be inversely proportional to thermal conductivity, according to Fourier's law. This relationship can be linearized by plotting temperature as a function of summed thermal resistance (Bullard, 1939):

$$
T(z)=T_{\mathrm{o}}+q \sum_{\mathrm{i}=1}^{N}\left(\frac{\Delta Z_{\mathrm{i}}}{k(z)_{\mathrm{i}}}\right)
$$

where

$$
\begin{array}{ll}
T & =\text { temperature, } \\
Z & =\text { depth, } \\
T_{\mathrm{o}} & =\text { bottom water temperature, } \\
\sum_{\mathrm{i}=1}^{N}\left(\frac{\Delta Z_{\mathrm{i}}}{k(Z)_{\mathrm{i}}}\right) & =\text { thermal resistance, and } \\
N & =\text { number of thermal conductivity mea- } \\
N & \text { surments. }
\end{array}
$$

In practice, $q$ and $T_{\mathrm{o}}$ are estimated by plotting $T(z)$ against summed thermal resistance.

\section{MSCL-I: photo image logger}

The MSCL-I scans the surface of archive-half cores and creates a digital image. The line-scan camera is equipped with three charge-coupled devices; each charge-coupled device has 1024 arrays. Light reflection from the sample surface passes through the lens and is split into three paths (red, green, and blue) by a beam splitter inside the line-scan camera. Then, each reflection is detected by the corresponding charge-coupled device. Finally, the signals are combined and the digital image is reproduced. Optical distortion downcore is avoided by precise movement of the camera. Spatial resolution is 100 pixels $/ \mathrm{cm}$.

\section{MSCL-C: color spectroscopy logger}

The MSCL-C system is equipped with a color spectrophotometer (Konica-Minolta, CM-2600d). The aluminum frame of the instrument allows operators to load up to seven core sections, and the sensor unit (including the spectrophotometer and small distance laser measuring system) translates along each section and moves down at each measurement point to measure the split archive core surface.

Light reflected from the sample surface is collected in the color spectrophotometer's integration sphere. The instrument's structure allows for the specular component to be included (SCI setting) or excluded (SCE setting). The SCE setting is the recommended mode of operation, especially for sediments, to ex- 
clude glare. The light is divided into wavelengths at a $10 \mathrm{~nm}$ pitch $(400-700 \mathrm{~nm})$, and the spectral sensors in the sphere convert the light to electrical currents proportional to the intensity of the light. Next, the color spectrum from the sample is normalized by the source light of the reflectance. The obtained spectrum is calibrated with the measurement of a pure white standard, which has a high reflectance true value at visible wavelengths and is measured by the vendor and with a black box (zero calibration). Measurements can be calculated based on the $2^{\circ}$ or $10^{\circ}$ standard observer and any of 11 illuminants.

Color reflectance is categorized as an IODP standard measurement, and the measured color spectrum is normally converted to $L^{*}, a^{*}$, and $b^{*}$ parameters. $L^{*}$, $\mathrm{a}^{*}$, and $\mathrm{b}^{*}$ provide relative changes in the composition of the bulk material and are widely used to correlate sections from core to core or hole to hole and to analyze the characteristic and cyclicity of lithologic changes.

\section{Core-log-seismic integration}

There was no downhole logging during Expedition 316. The integration of logging-while-drilling (LWD) data with seismic reflection data for Sites C0004 and C0006 was conducted during IODP Expedition 314. The reference seismic profiles are prestack depthmigrated lines from the CDEX and IFREE 3-D surveys (see Moore et al.). At Site C0004, seismic depthmigrated reflections were fit to the LWD check shot data by the Expedition 314 shipboard science party. However, at Site C0006, reflection depths had not yet been check shot-corrected at the time of Expedition 316.

The integration of cores with seismic data relies primarily on the presence of key boundaries, including unconformities, lithologic changes, and faults. Hole locations and MSCL-W data (e.g., NGR) are referenced to 3-D seismic data so that they can be accurately correlated to seismic data. Stratum and fault reflections in the 3-D seismic data are illuminated for the interpretation of lithology, structural patterns, and the integration between core and LWD data. Some of these reflections become key boundaries.

The integration of core data with LWD data relies primarily on correlations between lithologic boundaries and $P$-wave velocity and NGR from MSCL data. NGR data are especially useful for correlation between cores and logs. The LWD geoVISION resistivity tool was used at Sites C0004 and C0006 and comprises NGR measurements, resistivity measurements, and resistivity-at-the-bit (RAB) borehole images. Sonic log data are available from the sonicVISION tool and can also be compared with $P$-wave velocity from MSCL measurements on HPCS cores or with measurements on discrete samples (MAD and $P$-wave velocity measurements).

MSCL-W gamma emission data are reported in counts per second, and the only calibration is an ambient noise measurement ( 40 cps for MSCL-W). Values below 15 cps (or 55 cps before noise correction) were discarded because they often correspond to voids. The LWD gamma ray tool records natural gamma rays in the formations adjacent to the borehole. This nuclear measurement indicates the radioactive content of the formations. Its unit is American Petroleum Institute gamma ray unit (gAPI).

LWD depth below seafloor (LSF) is used as the depth reference for LWD logs. There are two definitions of core depth. In the standard definition of core depth below seafloor (CSF), the core depth is added to the depth of the drill bit at the beginning of coring. This definition leads to overlaps between expanded HPCS cores and, in some cases, between RCB cores when drilling fluid and/or cuttings enter the core barrel. The core depth below seafloor (CSF-B) depth is also given by J-CORES and corrects the discrepancy between the length of expanded cores and the advance of the drill bit by applying an arbitrary linear correction over the whole length of core. The correlation between core depth below seafloor and LWD depth below seafloor is based on the CSF-B depth in the intervals with expanded cores. Depth transfer functions are defined by linear regression between correlated peaks. In general, cores with $<50 \%$ recovery do not provide useful constraints. In intervals with better recovery, several peak-to-peak correlations within a single RCB core indicate that the core log may be condensed by $5 \%-30 \%$ with respect to LWD data. This is interpreted that partial recovery can be spread over most of the cored interval.

\section{References}

Archie, G.E., 1947. Electrical resistivity-an aid in core analysis interpretation. AAPG Bull., 31:350-366.

ASTM International, 1990. Standard method for laboratory determination of water (moisture) content of soil and rock (Standard D2216-90). In Annual Book of ASTM Standards for Soil and Rock (Vol. 04.08): Philadelphia (Am. Soc. Testing and Mater.).

Barron, J.A., 1985. Miocene to Holocene planktic diatoms. In Bolli, H.M., Saunders, J.B., and Perch-Nielsen, K. (Eds.), Plankton Stratigraphy: Cambridge (Cambridge Univ. Press), 763-809.

Biddle, J.F., Lipp, J.S., Lever, M.A., Lloyd, K.G., Sørensen, K.B., Anderson, R., Fredricks, H.F., Elvert, M., Kelly, T.J., Schrag, D.P., Sogin, M.L., Brenchley, J.E., Teske, A., House, C.H., and Hinrichs, K.-U., 2006. Heterotrophic Archaea dominate sedimentary subsurface ecosystems off Peru. Proc. Natl. Acad. Sci. U. S. A., 103(10):38463851. doi:10.1073/pnas.0600035103 
Blow, W.H., 1969. Late middle Eocene to Recent planktonic foraminiferal biostratigraphy. In Brönnimann, P., and Renz, H.H. (Eds.), Proc. First Int. Conf. Planktonic Microfossils, Geneva, 1967: Leiden (E.J. Brill), 1:199-422.

Blum, P., 1997. Physical properties handbook: a guide to the shipboard measurement of physical properties of deep-sea cores. ODP Tech. Note, 26. doi:10.2973/ odp.tn.26.1997

Bullard, E.C., 1939. Heat flow in South Africa. Proc. R. Soc. London, Ser. A, 173:474-502.

Clark, S.P. (Ed.), 1966. Handbook of Physical Constants. Spec. Publ.-Mem. Geol. Soc. Am., 97.

D'Hondt, S., Inagaki, F., Ferdelman, T., Jørgensen, B.B., Kato, K., Kemp, P., Sobecky, P., Sogin, M., and Takai, K., 2007. Exploring subseafloor life with the Integrated Ocean Drilling Program. Sci. Drill., 5:26-37. doi:10.2204/iodp.sd.5.03.2007

D’Hondt, S., Jørgensen, B.B., Miller, D.J., Batzke, A., Blake, R., Cragg, B.A., Cypionka, H., Dickens, G.R., Ferdelman, T., Hinrichs, K.-U., Holm, N.G., Mitterer, R., Spivack, A., Wang, G., Bekins, B., Engelen, B., Ford, K., Gettemy, G., Rutherford, S.D., Sass, H., Skilbeck, C.G., Aiello, I.W., Guerin, G., House, C.H., Inagaki, F., Meister, P., Naehr, T., Niitsuma, S., Parkes, R.J., Schippers, A., Smith, D.C., Teske, A., Wiegel, J., Naranjo Padillo, C., and Solis Acosta, J.L., 2004. Distributions of microbial activities in deep subseafloor sediments. Science, 306(5705):22162221. doi:10.1126/science.1101155

D'Hondt, S., Rutherford, S., and Spivack., A.J., 2002. Metabolic activity of the subsurface life in deep-sea sediments. Science, 295(5562):2067-2070. doi:10.1126/ science.1064878

Duan, Z., Møller, N., Greenberg, J., and Weare, J.H., 1992. The prediction of methane solubility in natural waters to high ionic strength from $0^{\circ}$ to $250^{\circ} \mathrm{C}$ and from 0 to 1600 bar. Geochim. Cosmochim. Acta, 56(4):1451-1460. doi:10.1016/0016-7037(92)90215-5

Engelen, B., Ziegelmüller, K., Wolf, L., Köpke, B., Gittel, A., Cypionka, H., Treude, T., Nakagawa, S., Inagaki, F., Lever, M.A., and Steinsbu, B.O., 2008. Fluids from the ocean crust support microbial activities within the deep biosphere. Geomicrobiol. J., 25(1):56-66. doi:10.1080/ 01490450701829006

Fisher, A.T., and Underwood, M.B., 1995. Calibration of an $\mathrm{X}$-ray diffraction method to determine relative mineral abundances in bulk powders using matrix singular value decomposition: a test from the Barbados accretionary complex. In Shipley, T.H., Ogawa, Y., Blum, P., et al., Proc. ODP, Init. Repts., 156: College Station, TX (Ocean Drilling Program), 29-37. doi:10.2973/ odp.proc.ir.156.103.1995

Fukatsu, T., 1999. Acetone preservation: a practical technique for molecular analysis. Mol. Ecol., 8(11):19351945.

Fuller, M., 1969. Magnetic orientation of borehole cores. Geophysics, 34(5):772-774.

GE Healthcare, 2006. LightSpeed Series Learning and Reference Guide-Multi Slice CT: Waukesha, Wisconsin (GE Healthcare), 936.
Gieskes, J.M., Gamo, T., and Brumsack, H., 1991. Chemical methods for interstitial water analysis aboard JOIDES Resolution. ODP Tech. Note, 15. doi:10.2973/ odp.tn.15.1991

Gradstein, F.M., Ogg, J.G., and Smith, A. (Eds.), 2004. A Geologic Time Scale 2004: Cambridge (Cambridge Univ. Press). http://www.stratigraphy.org/

Hinrichs, K.-U., Hayes, J.M., Bach, W., Spivack, A.J., Hmelo, L.R., Holm, N.G., Johnson, C.G., and Sylva, S.P., 2006. Biological formation of ethane and propane in the deep marine subsurface. Proc. Natl. Acad. Sci. U.S.A. 103(40):14686-14689. doi:10.1073/pnas.0606535103

Hinrichs, K.-U., Hayes, J.M., Sylva, S.P., Brewer, P.G., and DeLong, E.F., 1999. Methane-consuming archaebacteria in marine sediments. Nature (London, U. K.), 398(6730):802-805. doi:10.1038/19751

Hulme, S.M., Wheat, C.G., Coggon, R.M., and McManus, J., 2008. Data report: trace element, Sr isotope, and Ge/ Si composition of fluids and sediments in ridge-flank low-temperature hydrothermal environments. In Fisher, A.T., Urabe, T., Klaus, A., and the Expedition 301 Scientists, Proc. IODP, 301: College Station, TX (Integrated Ocean Drilling Program Management International, Inc.). doi:10.2204/iodp.proc.301.202.2008

Inagaki, F., Kuypers, M.M.M., Tsunogai, U., Ishibashi, J.-I., Nakamura, K.-I., Treude, T., Ohkubo, S., Nakaseama, M., Gena, K., Chiba, H., Hirayama, H., Nunoura, T., Takai, K., Jørgensen, B.B., Horikoshi, K., and Boetius, A., 2006a. Microbial community in a sediment-hosted $\mathrm{CO}_{2}$ lake of the southern Okinawa Trough hydrothermal system. Proc. Natl. Acad. Sci. U.S.A., 103(38):14164-14169. doi:10.1073/pnas.0606083103

Inagaki, F., Nunoura, T., Nakagawa, S., Teske, A., Lever, M., Lauer, A., Suzuki, M., Takai, K., Delwiche, M., Colwell, F.S., Nealson, K.H., Horikoshi, K., D'Hondt, S., and Jørgensen, B.B., 2006b. Biogeographical distribution and diversity of microbes in methane hydrate-bearing deep marine sediments on the Pacific Ocean margin. Proc. Natl. Acad. Sci. U. S. A., 103(8):2815-2820. doi:10.1073/ pnas.0511033103

Inagaki, F., Suzuki, M., Takai, K., Oida, H., Sakamoto, T., Aoki, K., Nealson, K.H., and Horikoshi, K., 2003. Microbial communities associated with geological horizons in coastal subseafloor sediments from the Sea of Okhotsk. Appl. Environ. Microbiol., 69(12):7224-7235. doi:10.1128/AEM.69.12.7224-7235.2003

Kamikuri, S., Nishi, H., Motoyama, I., and Saito, S., 2004. Middle Miocene to Pleistocene radiolarian biostratigraphy in the northwest Pacific Ocean, ODP Leg 186. Isl. Arc, 13(1):191-226.

Keenan, J.H., Keyes, F.G., Hill, P.G., and Moore, J.G., 1978. Steam Tables: Thermodynamic Properties of Water Including Vapor, Liquid, and Solid Phases (International System of Units; S.I.): New York (John Wiley \& Sons).

Kimura, G., Silver, E.A., Blum, P., et al., 1997. Proc. ODP, Init. Repts., 170: College Station, TX (Ocean Drilling Program). doi:10.2973/odp.proc.ir.170.1997

Kirschvink, J.L., 1980. The least-squares line and plane and the analysis of palaeomagnetic data. Geophys. J. R. Astron. Soc., 62(3):699-718. 
Kobayashi, T., Koide, O., Mori, K., Shimamura, S., Matsuura, T., Miura, T., Takaki, Y., Morono, Y., Nunoura, T., Imachi, H., Inagaki, F., Takai, K., and Horikoshi, K., 2008. Phylogenetic and enzymatic diversity of deep subseafloor aerobic microorganisms in organics- and methane-rich sediments off Shimokita Peninsula. Extremophiles, 12(4):519-527. doi:10.1007/s00792-008-0157-7

Kodama, K.P., 1984. Palaeomagnetism of granitic intrusives from the Precambrian basement under eastern Kansas: orienting drill cores using secondary magnetization components. Geophys. J. R. Astron. Soc., 76:273-287.

Lipp, J.S., Morono, Y., Inagaki, F., and Hinrichs K.-U., 2008. Significant contribution of Archaea to extant biomass in marine subsurface sediments. Nature (London, U. K.), 454(7207): 991-994. doi:10.1038/nature07174

Louis, L., Robion, P., and David, C., 2004. A single method for the inversion of anisotropic data sets with application to structural studies. J. Struct. Geol., 26(11):20652072. doi:10.1016/j.jsg.2004.03.005

Lourens, L.J., Hilgen, F.J., Shackleton, N.J., Laskar, J., and Wilson, D., 2004. The Neogene period. In Gradstein, F.M., Ogg, J.G., and Smith, A.G. (Eds.), A Geological Time Scale 2004. Cambridge (Cambridge Univ. Press), 409-440.

Lunau, M., Lemke, A., Walther, K., Martens-Habbena, W., and Simon, M., 2005. An improved method for counting bacteria from sediments and turbid environments by epifluorescence microscopy. Environ. Microbiol., 7(7):961-968. doi:10.1111/j.1462-2920.2005.00767.x

Manheim, F.T., 1966. A hydraulic squeezer for obtaining interstitial waters from consolidated and unconsolidated sediments. Geol. Surv. Prof. Pap. (U.S.), 550-C:256261.

Martini, E., 1971. Standard Tertiary and Quaternary calcareous nannoplankton zonation. In Farinacci, A. (Ed.), Proc. 2nd Int. Conf. Planktonic Microfossils Roma: Rome (Ed. Tecnosci.), 2:739-785.

Maruyama, T., and Shiono, M., 2003. Middle Miocene to Pleistocene diatom biostratigraphy of the northwest Pacific at Sites 1150 and 1151. In Suyehiro, K., Sacks, I.S., Acton, G.D., and Oda, M. (Eds.), Proc. ODP, Sci. Results, 186: College Station, TX (Ocean Drilling Program), 1-38. doi:10.2973/odp.proc.sr.186.106.2003

Masui, N., Morono, Y., and Inagaki, F., 2008. Microbiological assessment of circulation mud fluids during the first operation of riser drilling by the deep-earth research vessel Chikyu. Geomicrobiol. J., 25(6):274-282. doi:10.1080/01490450802258154

Mazzullo, J., and Graham, A.G. (Eds.), 1988. Handbook for shipboard sedimentologists. ODP Tech. Note, 8. doi:10.2973/odp.tn.8.1988

Mazzullo, J.M., Meyer, A., and Kidd, R.B., 1988. Appendix I: new sediment classification scheme for the Ocean Drilling Program. In Mazzullo, J.M., and Graham, A.G. (Eds.), Handbook for shipboard sedimentologists. ODP Tech. Note, 8:45-67. doi:10.2973/odp.tn.8.1988

McFadden, P.L., and Reid, A.B., 1982. Analysis of paleomagnetic inclination data. Geophys. J. R. Astron. Soc., 69:307-319.

Mees, F., Swennen, R., Van Geet, M. and Jacobs, P., 2003. Applications of X-ray computed tomography in the geosciences. Geol. Soc. Spec. Publ., 215(1):1-6. doi:10.1144/GSL.SP.2003.215.01.01

Moore, G.F., Taira, A., Klaus, A., et al., 2001. Proc. ODP, Init. Repts., 190: College Station, TX (Ocean Drilling Program). doi:10.2973/odp.proc.ir.190.2001

Nakano, T., Nakashima, Y., Nakamura, K., and Ikeda, S., 2000. Observation and analysis of internal structure of rock using X-ray CT. Chishitsugaku Zasshi, 106(5):363378.

Nigrini, C., and Sanfilippo, A., 2001. Cenozoic radiolarian stratigraphy for low and middle latitudes with descriptions of biomarkers and stratigraphically useful species. ODP Tech. Note, 27. doi:10.2973/odp.tn.27.2001

Okada, H., and Bukry, D., 1980. Supplementary modification and introduction of code numbers to the lowlatitude coccolith biostratigraphic zonation (Bukry, 1973; 1975). Mar. Micropaleontol., 5:321-325. doi:10.1016/0377-8398(80)90016-X

Parkes, R.J., Cragg, B.A., Bale, S.J., Getliff, J.M., Goodman, K., Rochelle, P.A., Fry, J.C., Weightman, A.J., and Harvey, S.M., 1994. Deep bacterial biosphere in Pacific Ocean sediments. Nature (London, U. K.), 371(6496):410-413. doi:10.1038/371410a0

Parkes, R.J., Cragg, B.A., and Wellsbury, P., 2000. Recent studies on bacterial populations and processes in subseafloor sediments: a review. Hydrogeol. J., 8(1):11-28. doi:10.1007/PL00010971

Parkes, R.J., Webster, G., Cragg, B.A., Weightman, A.J., Newberry, C.J., Ferdelman, T.G., Kallmeyer, J., Jørgensen, B.B., Aiello, I.W., and Fry, J.C., 2005. Deep sub-seafloor prokaryotes stimulated at interfaces over geological time. Nature (London, U. K.), 436(7049):390394. doi:10.1038/nature03796

Perch-Nielsen, K., 1985. Cenozoic calcareous nannofossils. In Bolli, H.M., Saunders, J.B., and Perch-Nielsen, K. (Eds.), Plankton Stratigraphy: Cambridge (Cambridge Univ. Press), 427-554.

Pimmel, A., and Claypool, G., 2001. Introduction to shipboard organic geochemistry on the JOIDES Resolution. ODP Tech. Note, 30. doi:10.2973/odp.tn.30.2001

Raffi, I., Backman, J., Fornaciari, E., Pälike, H., Rio, D., Lourens, L., and Hilgen, F., 2006. A review of calcareous nannofossil astrobiochronology encompassing the past 25 million years. Quat. Sci. Rev., 25(23-24):3113-3137. doi:10.1016/j.quascirev.2006.07.007

Ratcliffe, E.H., 1960. The thermal conductivities of ocean sediments. J. Geophys. Res., 65:1535-1541.

Richter, C., Acton, G., Endris, C., and Radsted, M., 2007. Handbook for shipboard paleomagnetists. ODP Tech. Note, 34. doi:10.2973/odp.tn.34.2007

Rothwell, R.G., 1989. Minerals and Mineraloids in Marine Sediments: An Optical Identification Guide: London, UK (Elsevier).

Sakamoto, T., Kuroki, K., Sugawara, T., Aoike, K., Iijima, K., and Sugisaki, S., 2006. Non-destructive X-ray fluorescence (XRF) core-imaging scanner, TATSCAN-F2. Sci. Drill., 2:37-9.

Schippers, A., Neretin, L.N., Kallmeyer, J., Ferdelman, T.G., Cragg, B.A., Parkes R.J., and Jørgensen, B.B., 2005. 
Prokaryotic cells of the deep sub-seafloor biosphere identified as living bacteria. Nature (London, U. K.), 433(7028):861-864. doi:10.1038/nature03302

Shepard, F.P., 1954. Nomenclature based on sand-silt-clay ratios. J. Sediment. Petrol., 24(3):151-158.

Shibuya, H., Merrill, D.L., Hsu, V., and Leg 124 Shipboard Scientific Party, 1991. Paleogene counterclockwise rotation of the Celebes Sea-orientation of ODP cores utilizing the secondary magnetization. In Silver, E.A., Rangin, C., von Breymann, M.T., et al., Proc. ODP, Sci. Results, 124: College Station, TX (Ocean Drilling Program), 519523. doi:10.2973/odp.proc.sr.124.169.1991

Shipboard Scientific Party, 2003. Explanatory notes. In D'Hondt, S.L., Jørgensen, B.B., Miller, D.J., et al., Proc. ODP, Init. Repts., 201: College Station, TX (Ocean Drilling Program), 1-103. doi:10.2973/ odp.proc.ir.201.105.2003

Shipley, T.H., Ogawa, Y., Blum, P., et al., 1995. Proc. ODP, Init. Repts., 156: College Station, TX (Ocean Drilling Program). doi:10.2973/odp.proc.ir.156.1995

Smith, D.C., Spivack, A.J., Fisk, M.R., Haveman, S.A., and Staudigel, H., 2000a. Tracer-based estimates of drillinginduced microbial contamination of deep sea crust. Geomicrobiol. J., 17(3):207-219. doi:10.1080/ 01490450050121170

Smith, D.C., Spivack, A.J., Fisk, M.R., Haveman, S.A., Staudigel, H., and the Leg 185 Shipboard Scientific Party, 2000b. Methods for quantifying potential microbial contamination during deep ocean coring. ODP Tech. Note, 28. doi:10.2973/odp.tn.28.2000

Su, X., 1996. Development of late Tertiary and Quaternary coccolith assemblages in the northeast Atlantic. GEOMAR Rep., 48.

Taira, A., Hill, I., Firth, J.V., et al., 1991. Proc. ODP, Init. Repts., 131: College Station, TX (Ocean Drilling Program). doi:10.2973/odp.proc.ir.131.1991

Tauxe, L., 1998. Paleomagnetic Principles and Practice: Dordrecht, Netherlands (Kluwer Academic Publishers).
Tauxe, L., Tucker, P., Peterson, N.P., and LaBrecque, J.L., 1984. Magnetostratigraphy of Leg 73 sediments. In Hsü, K.J., LaBrecque, J.L., et al., Init. Repts. DSDP, 73: Washington, DC (U.S. Govt. Printing Office), 609-621. doi:10.2973/dsdp.proc.73.123.1984

Underwood, M.B., Basu, N., Steurer, J., and Udas, S., 2003. Data report: normalization factors for semiquantitative X-ray diffraction analysis, with application to DSDP Site 297, Shikoku Basin. In Mikada, H., Moore, G.F., Taira, A., Becker, K., Moore, J.C., and Klaus, A. (Eds.), Proc. ODP, Sci. Results, 190/196: College Station, TX (Ocean Drilling Program), 1-28. doi:10.2973/ odp.proc.sr.190196.203.2003

Vacquier, V., 1985. The measurement of thermal conductivity of solids with a transient linear heat source on the plane surface of a poorly conducting body. Earth Planet. Sci. Lett., 74(2-3):275-279. doi:10.1016/0012821X(85)90027-5

Von Herzen, R.P., and Maxwell, A.E., 1959. The measurement of thermal conductivity of deep-sea sediments by a needle-probe method. J. Geophys. Res., 64:1557-1563.

Wheat, C.G., Mottl, M.J., and Rudnicki, M., 2002. Trace element and REE composition of a low-temperature ridge-flank hydrothermal spring. Geochim. Cosmochim. Acta, 66(21):3693-3705. doi:10.1016/ S0016-7037(02)00894-3

Young, J.R., 1999. Neogene. In Bown, P.R. (Ed.), Calcareous Nannofossil Biostratigraphy: Dordrecht (Kluwer Academic Publ.), 225-265.

Zoth, G., and Haenel, R., 1988. Appendix: 1. In Haenel, R., Rybach, L., and Stegena, L. (Eds.), Handbook of Terrestrial Heat-Flow Density Determination: with Guidelines and Recommendations of the International Heat Flow Commission: Dordrecht (Kluwer Acad. Publ.), 449-4668.

Publication: 11 March 2009

MS 314315316-132 
Expedition 316 Scientists

Expedition 316 methods

Figure F1. IODP conventions for naming sites, holes, cores, and samples.

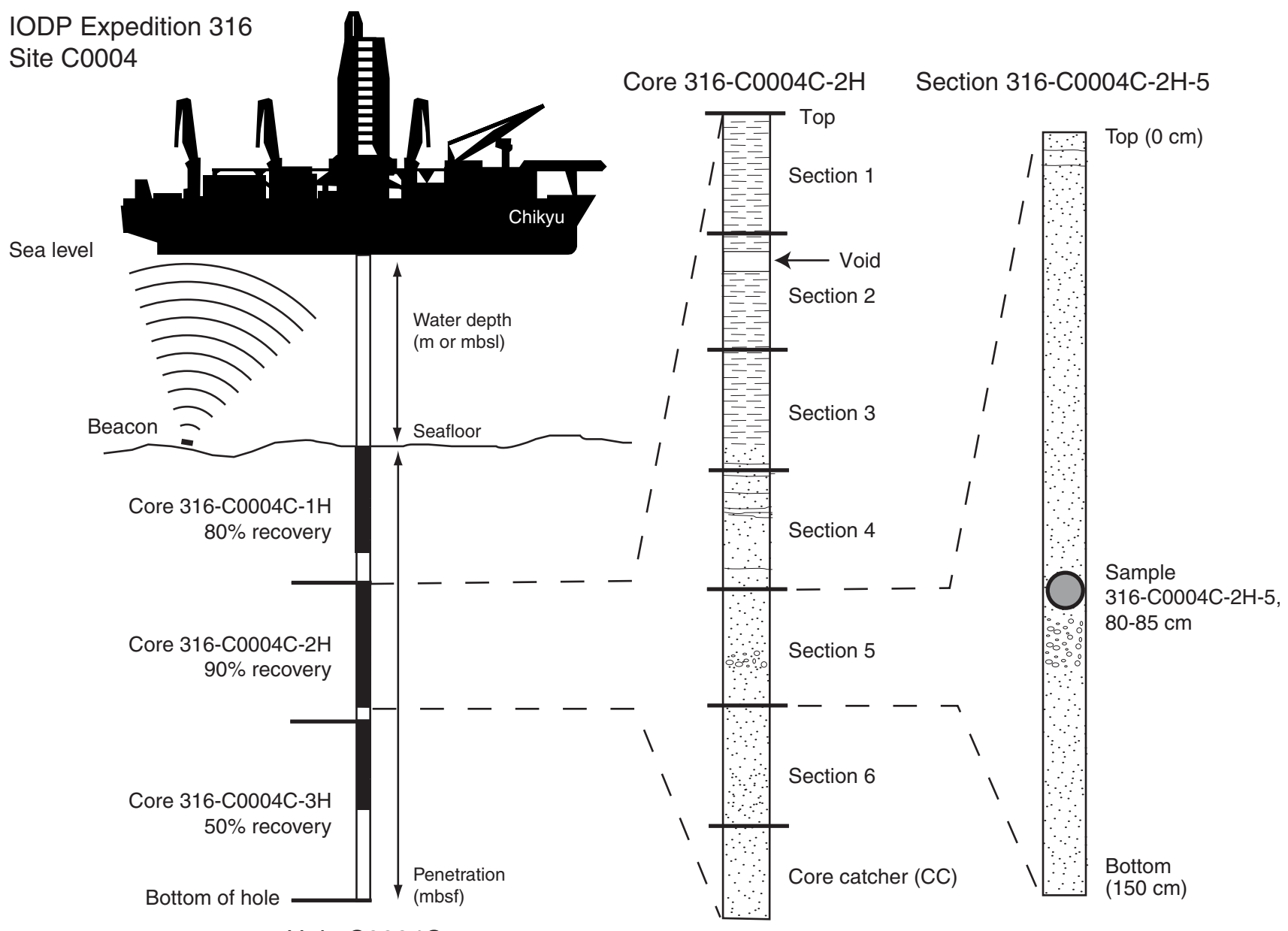

Hole C0004C

Proc. IODP | Volume 314/315/316

35 
Figure F2. Standard core flow from rig floor through core cutting, core processing, description, sampling, and storage area. CC = core catcher, MWJ = Marine Works Japan, PAL $=$ paleontology, $\mathrm{IW}=$ interstitial water, $\mathrm{WRC}=$ whole-round core, $\mathrm{CT}=$ computed tomography, $\mathrm{QA} / \mathrm{QC}=\mathrm{quality}$ assurance/quality control, $\mathrm{MBIO}=$ microbiology, $\mathrm{VCD}=$ visual core description, $\mathrm{MSCL}=$ multisensor core logger, MSCL-C = contact core logger, MSCL-I = imaging core logger.

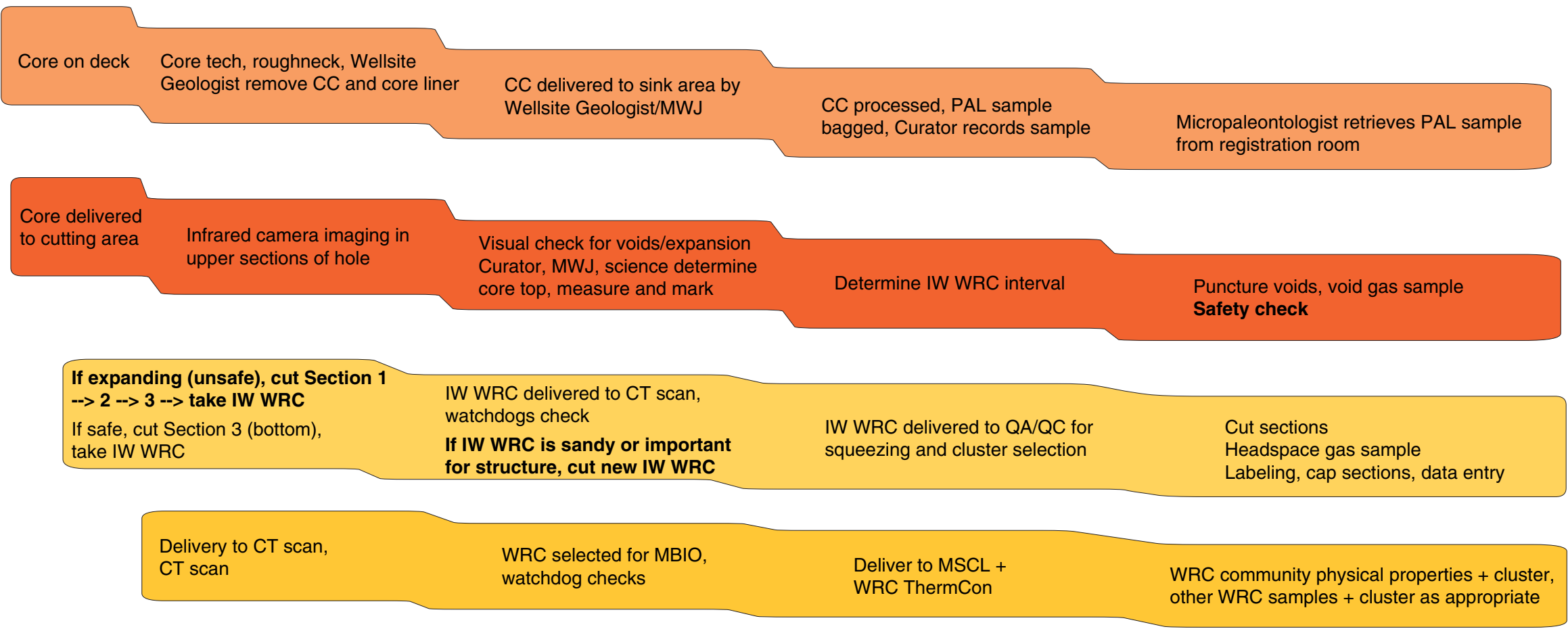

Deliver to splitting after final check by science party contact, watchdogs

\begin{tabular}{l|lll}
\hline Archive half to VCD (smear slide, description) & To MSCL-C, MSCL-I & To paleomag & $\begin{array}{l}\text { Deliver to storage } \\
\text { (scientists final check, approve for storage) }\end{array}$ \\
\hline & $\begin{array}{llll}\text { Working half to structure/sampling table } \\
\text { (structural description, phys. props, split core ThermCon) }\end{array}$ & $\begin{array}{l}\text { Sampling } \\
\text { (paleo, thin section, personal, etc.) }\end{array}$ & $\begin{array}{l}\text { Deliver to storage } \\
\text { (scientists final check, approve for storage) }\end{array}$ \\
\hline
\end{tabular}

In structurally important sections, splitting was delayed after CT scanning based on the advice of the watchdog scientists in charge of oversight. These cores remained in storage until a detailed sampling plan was worked out. In addition, cores of interest for structural sampling were held back from general sampling until all interested parties inspected the CT scan and agreed on a sampling plan. 
Figure F3. Detail of fault zone core handling. See "Special handling" for the procedure. Archive half and working half rotated with respect to core liner orientations (see inset for orientations and geometry). Test sample made up from trimmings material, fixed with epoxy, and cut with alcohol-cooled rock saw. Slab material used for comprehensive structural and microstructural thin sectioning, sampling, and description. One part of QRND-E sample set aside for future experimental, dating, and microanalysis (orange line). QRND = quarterround (see text for details).

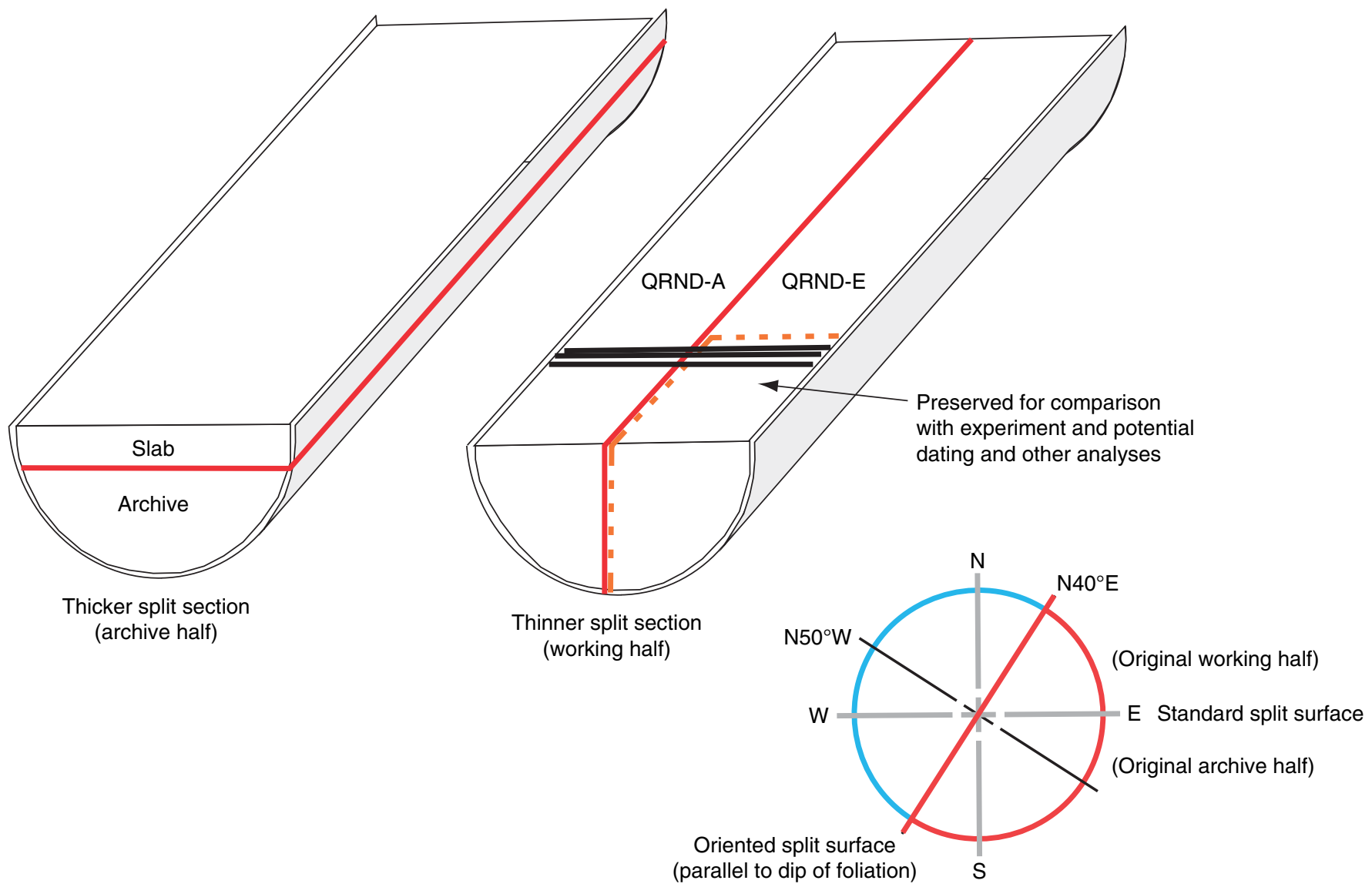


Figure F4. CT scans. A. Large number of cracks resulting from gas expansion (Section 316-C0004C-5H-5). Cracks do not contain clasts, mud water, or any other high-density materials. B. Typical structure of core sample after suffering spiral rotation within the core liner. Core is 2.5 inches across. White spots, possibly pyrite, can serve as rotation markers. $\mathrm{CT}=$ computed tomography.

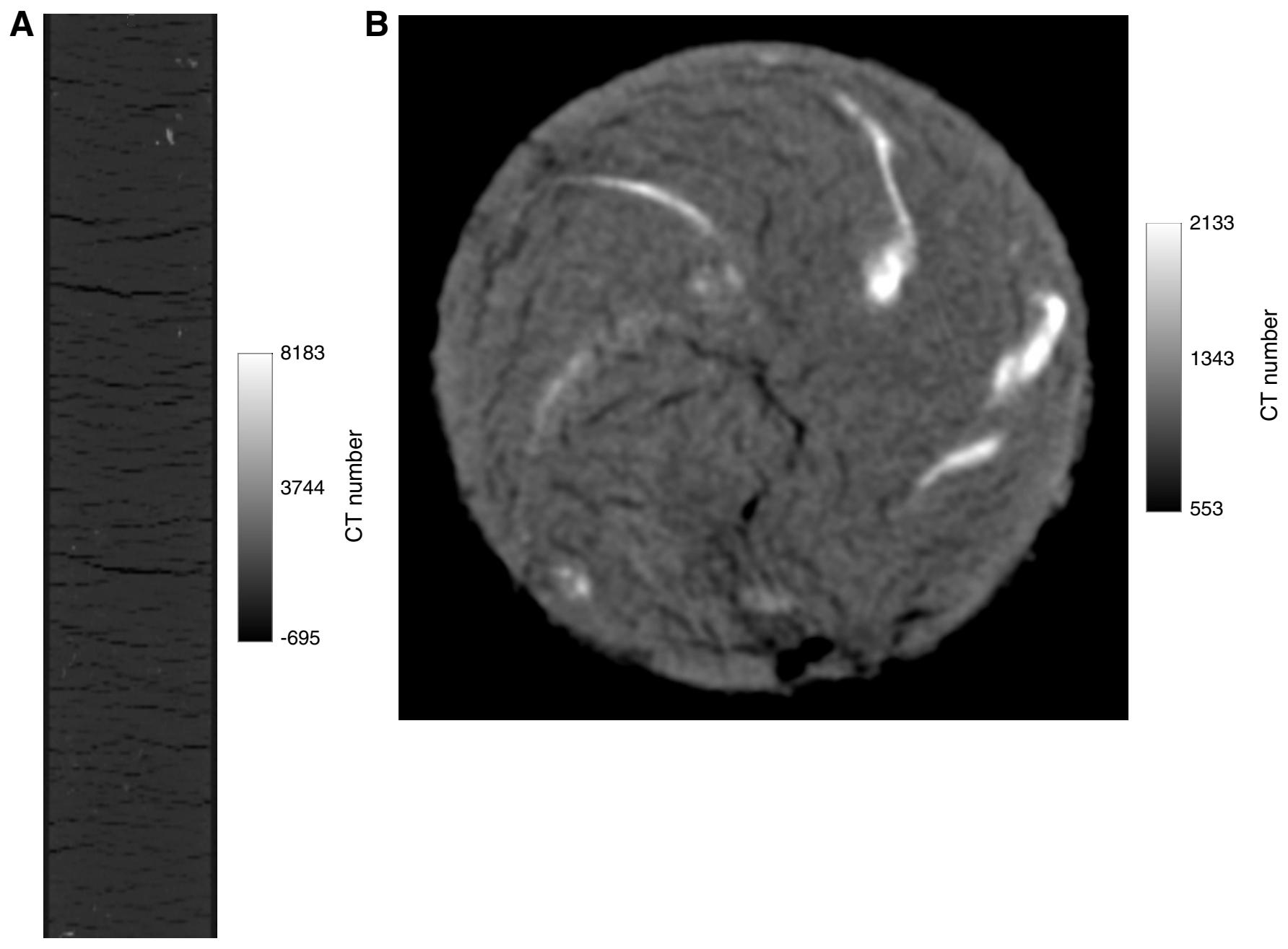


Figure F5. CT scans. A. Section 316-C0004C-15X-5 obtained by ESCS displays drilling-induced disruption in the form of biscuit blocks. B. Core recovery and conditions are better under similar drilling conditions after switching to HPCS (Section 316-C0004C-18H-1). Both cores are 2.5 inches in maximum diameter. CT $=$ computed tomography.

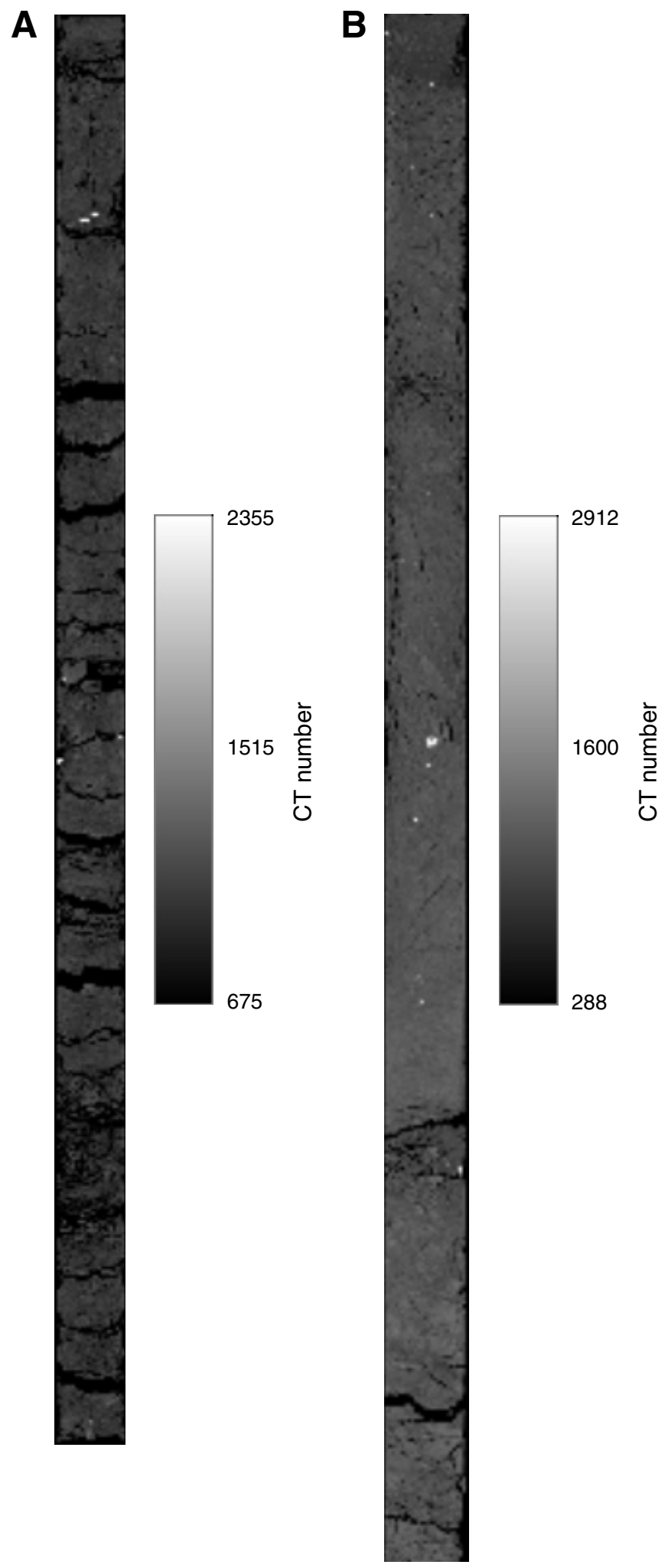


Figure F6. Section 316-C0004C-7H-1. A. X-ray computed tomography (CT) image of fault zone. Core is 2.5 inches across. B. Digital photomicrograph.

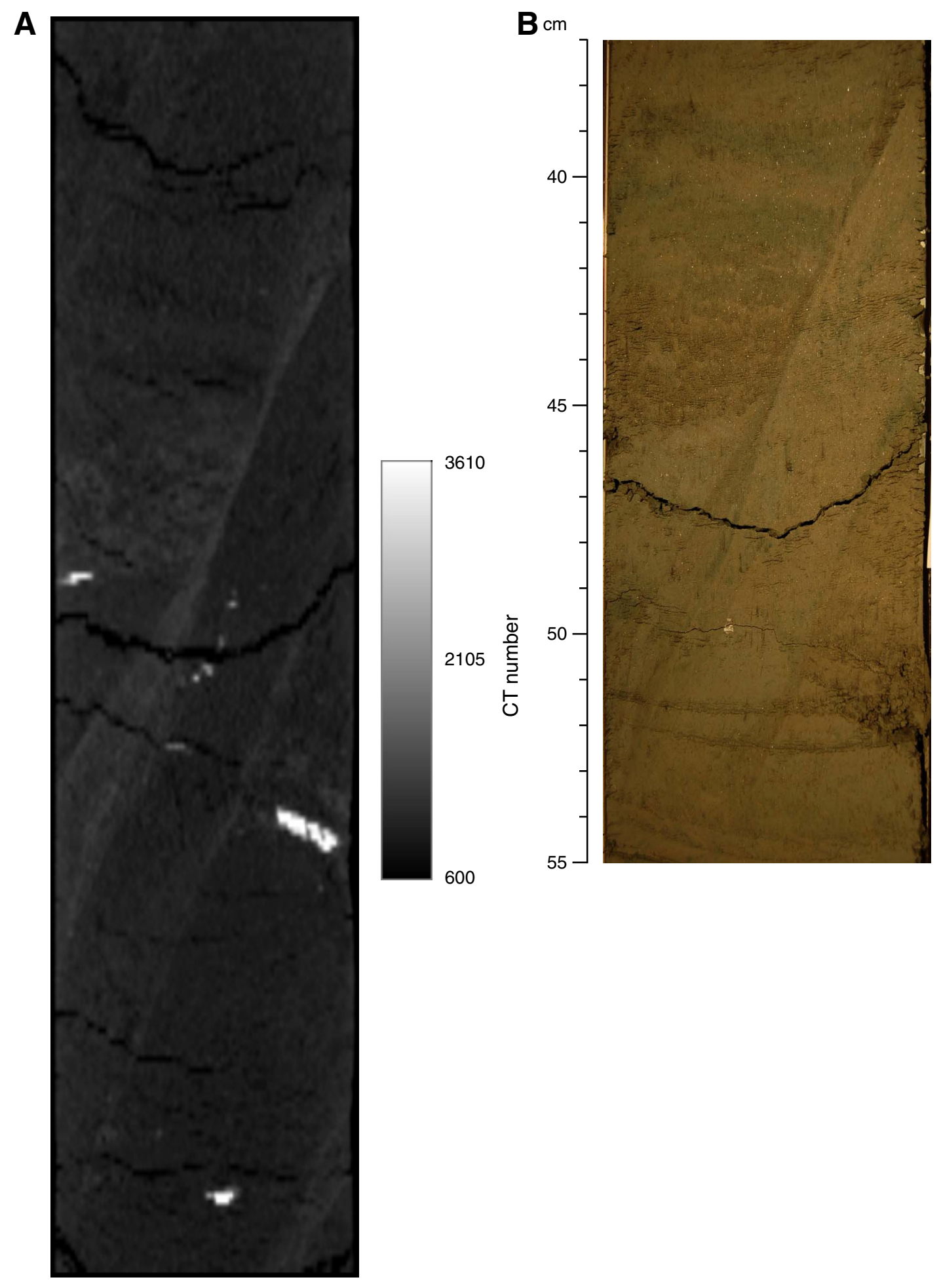


Figure F7. Graphic patterns and symbols used on visual core descriptions during Expedition 316.

\begin{tabular}{|c|c|}
\hline \multicolumn{2}{|l|}{ Lithology } \\
\hline & Silty clay/clayey silt \\
\hline & Silt \\
\hline & Silty sand/sandy silt \\
\hline & Sand \\
\hline$\because \therefore$ & Gravel \\
\hline & Sedimentary breccia \\
\hline & Volcanic fine ash \\
\hline & Void \\
\hline & Extracted core (sampl \\
\hline
\end{tabular}

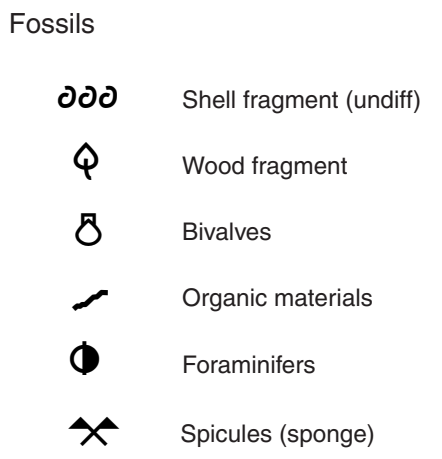

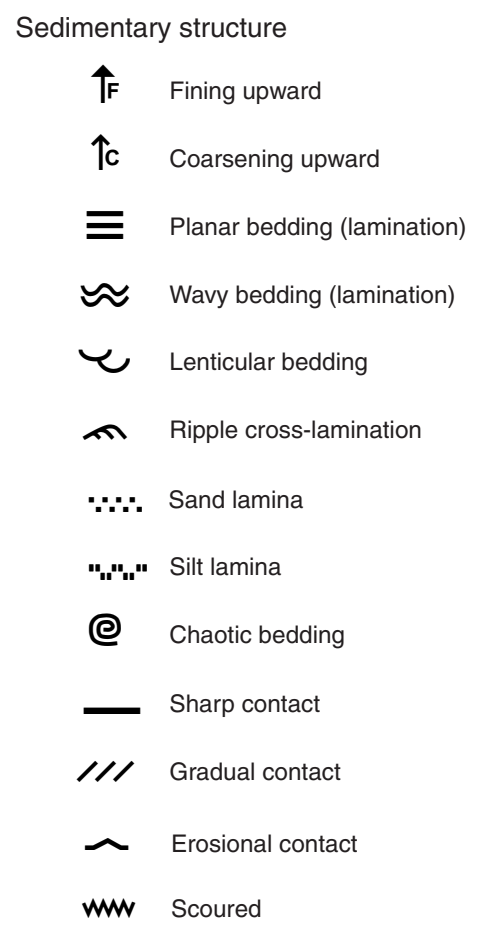

Bioturbation

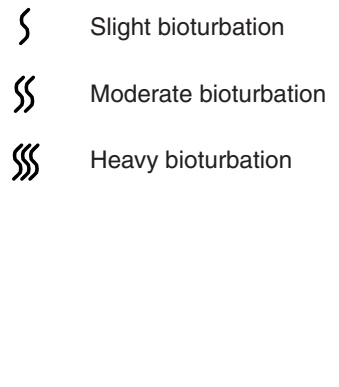

Core disturbance (drilling and/or splitting)

Slightly disturbed

i Moderately disturbed

+ Heavily disturbed

¿ Soupy

$\oslash$ Biscuit

1/, Slightly fractured

$\perp$ Moderately fractured

২ Highly fractured

\ Drilling breccia

几 Flow-in

Lithologic accessory
$\square$ Patch of minor lithology/Patch
Lth Synsedimentary clast (lithoclast)
$\boldsymbol{\nabla} \nabla$ Mud clast

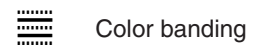
::- Silt/Sand scattering
- Isolated pebble
$\bigcirc$ General nodule/Concretion
Py Pyrite
(P) Pumice
GI Glauconite
? Others 
Figure F8. Diffractograms of mixtures of standard minerals showing positions of diagnostic peaks used to calculate relative mineral abundance. $\mathrm{Cl}=$ total clay minerals, $\mathrm{Q}=$ quartz, $\mathrm{P}=$ plagioclase, $\mathrm{Cc}=$ calcite.
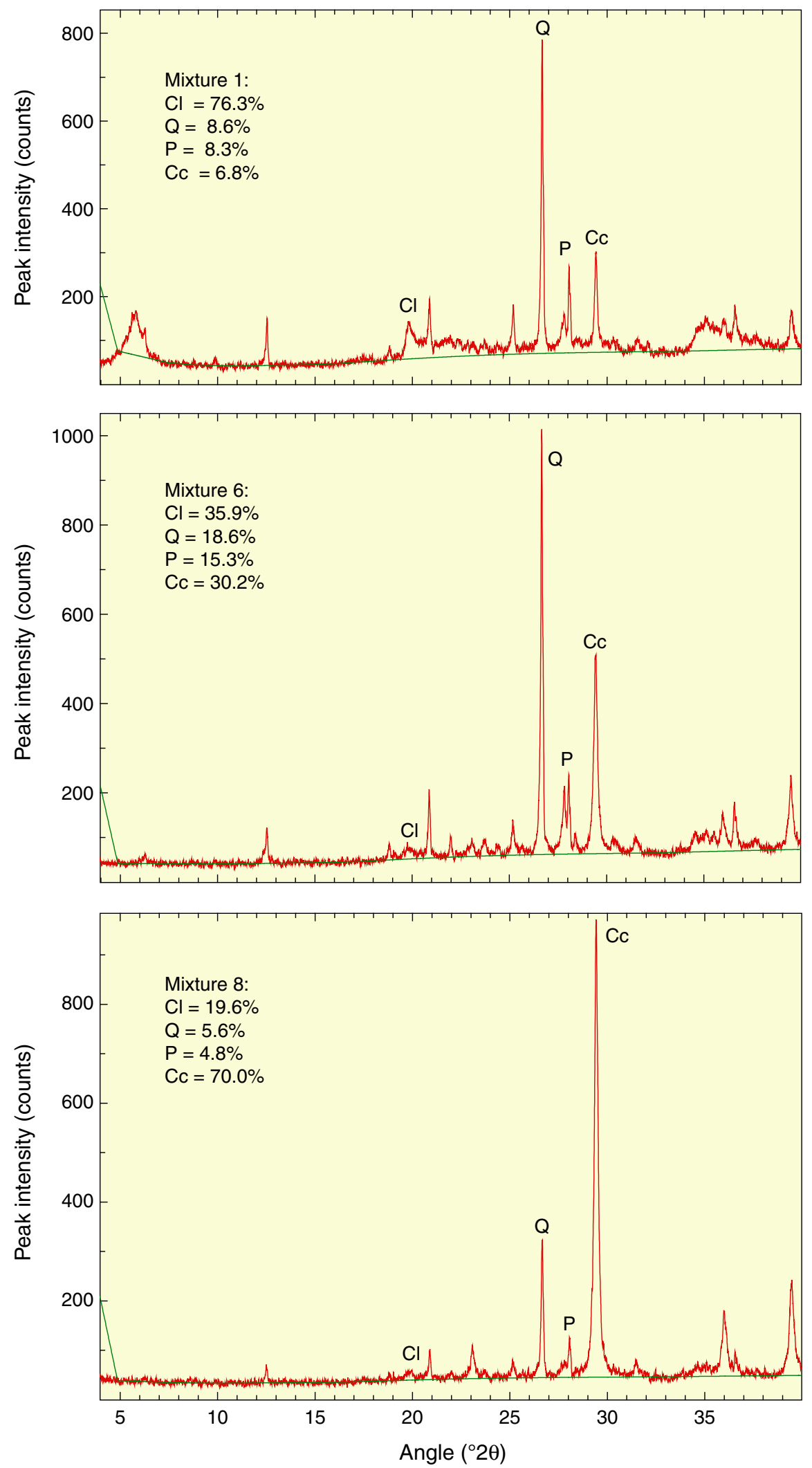
Figure F9. X-ray total intensities along first scan across the unconformity (Section 316-C0004C-9H-5). Orange arrow $=$ approximate position of the unconformity. Intervals of low intensity arise from sample surface topography that either blocked excitation X-rays from striking the sample or prevented generated X-rays from entering the detector.

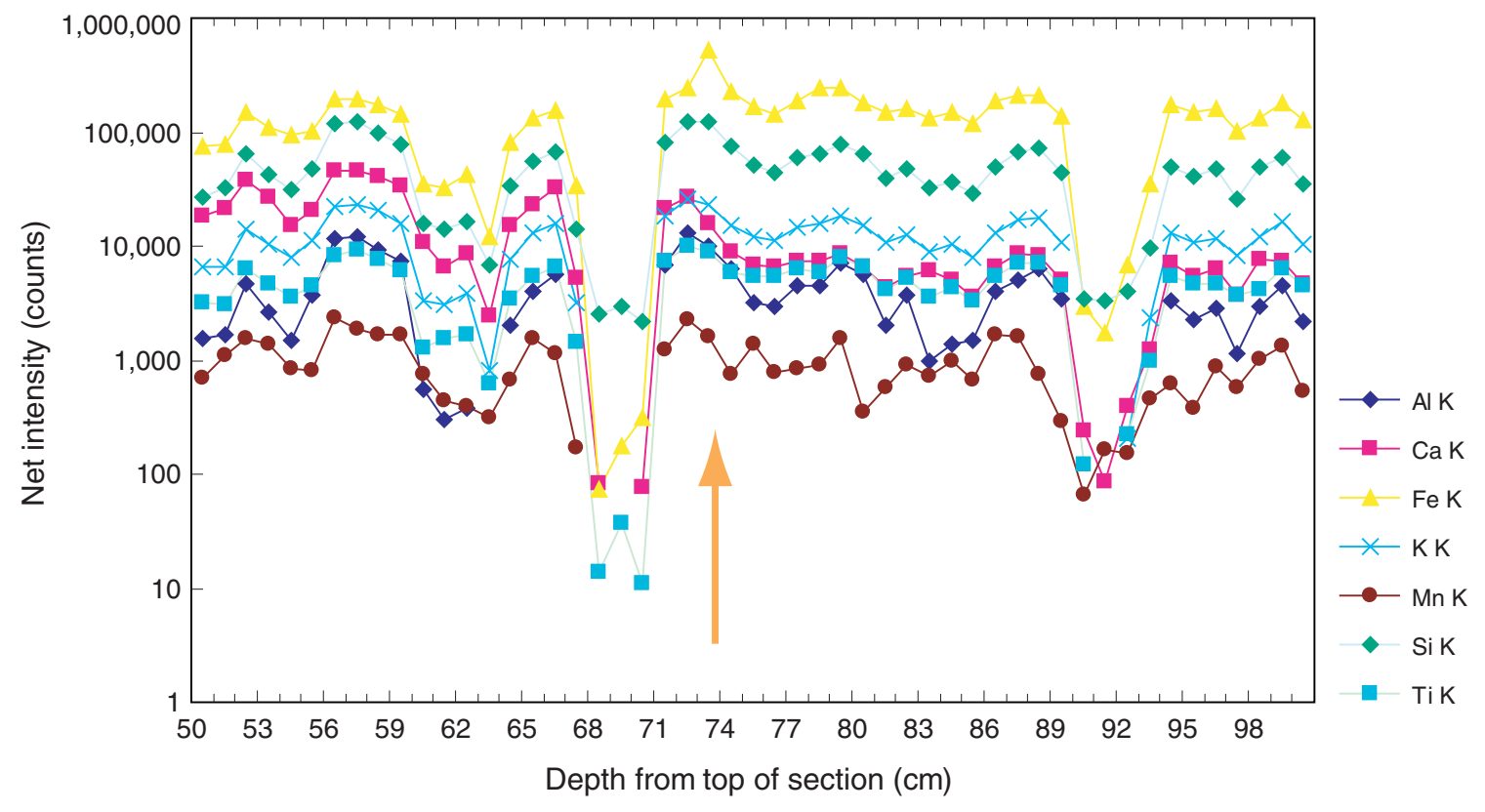


Figure F10. Semiquantitative oxides for second higher-resolution scan across the unconformity (Section 316-C0004C-9H-5). Blue lines $=$ upper and lower boundaries of breccia, dashed yellow line = position of XRF scan line.

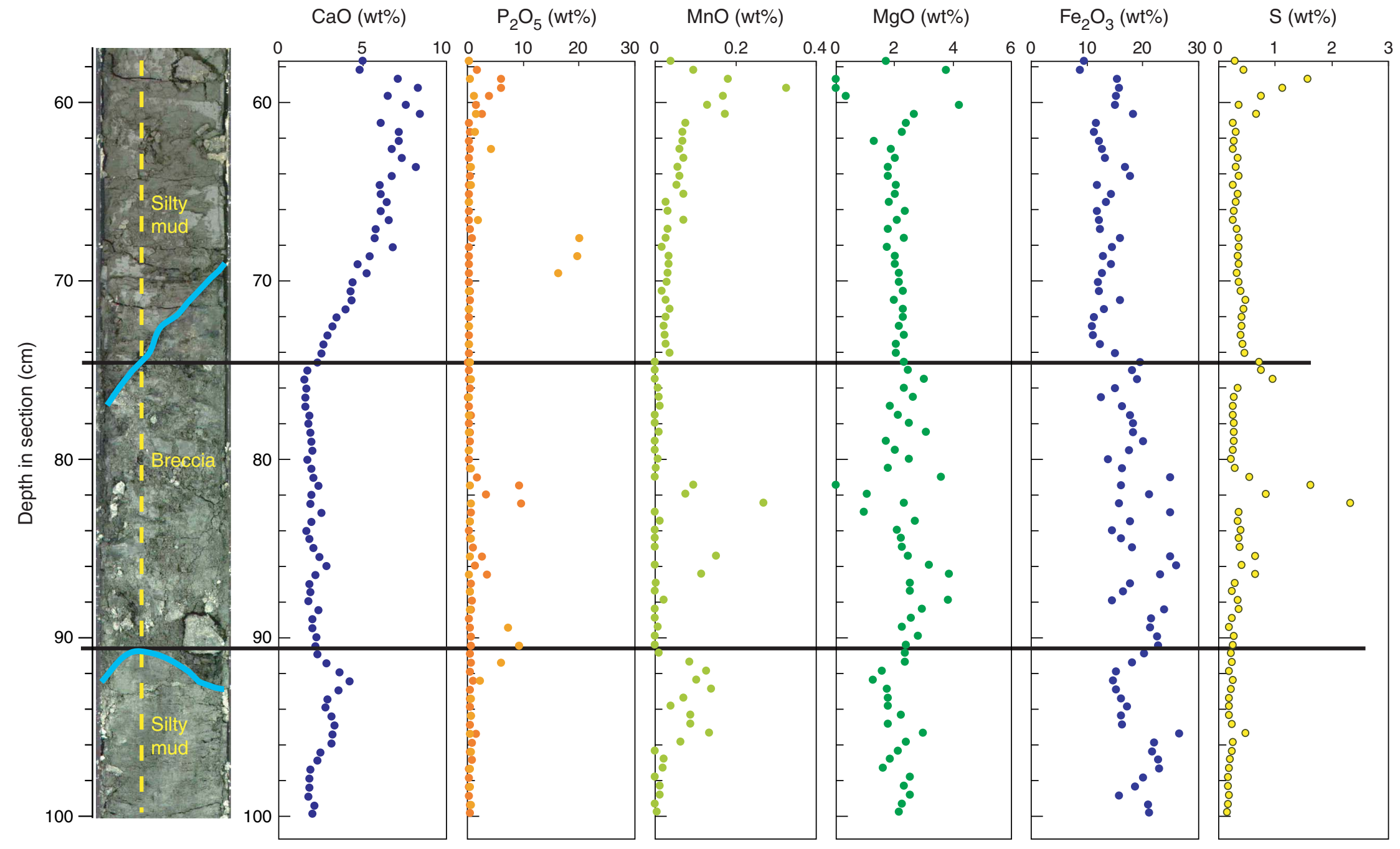


Figure F11. Depth variation of eight elements determined by XRF powder analysis on either side of the unconformity (Section 316-C0004C-9H-5). Covariations between $\mathrm{Ca}, \mathrm{Mg}$, and $\mathrm{Mn}$ suggest these elements reflect changes in the calcite fraction. Variations in Fe and $\mathrm{S}$ reflect abundant pyrite at the unconformity, whereas covariations in $\mathrm{Al}, \mathrm{Si}$, and $\mathrm{Ti}$ may reflect complementary reductions in these elements as a consequence of relative pyrite abundance. Covariation between $\mathrm{Ca}$ and $\mathrm{Mn}$ as seen in the crossplot (lower right) may have implications for understanding the trend of diminishing carbonate in calcareous mudstones above the unconformity.
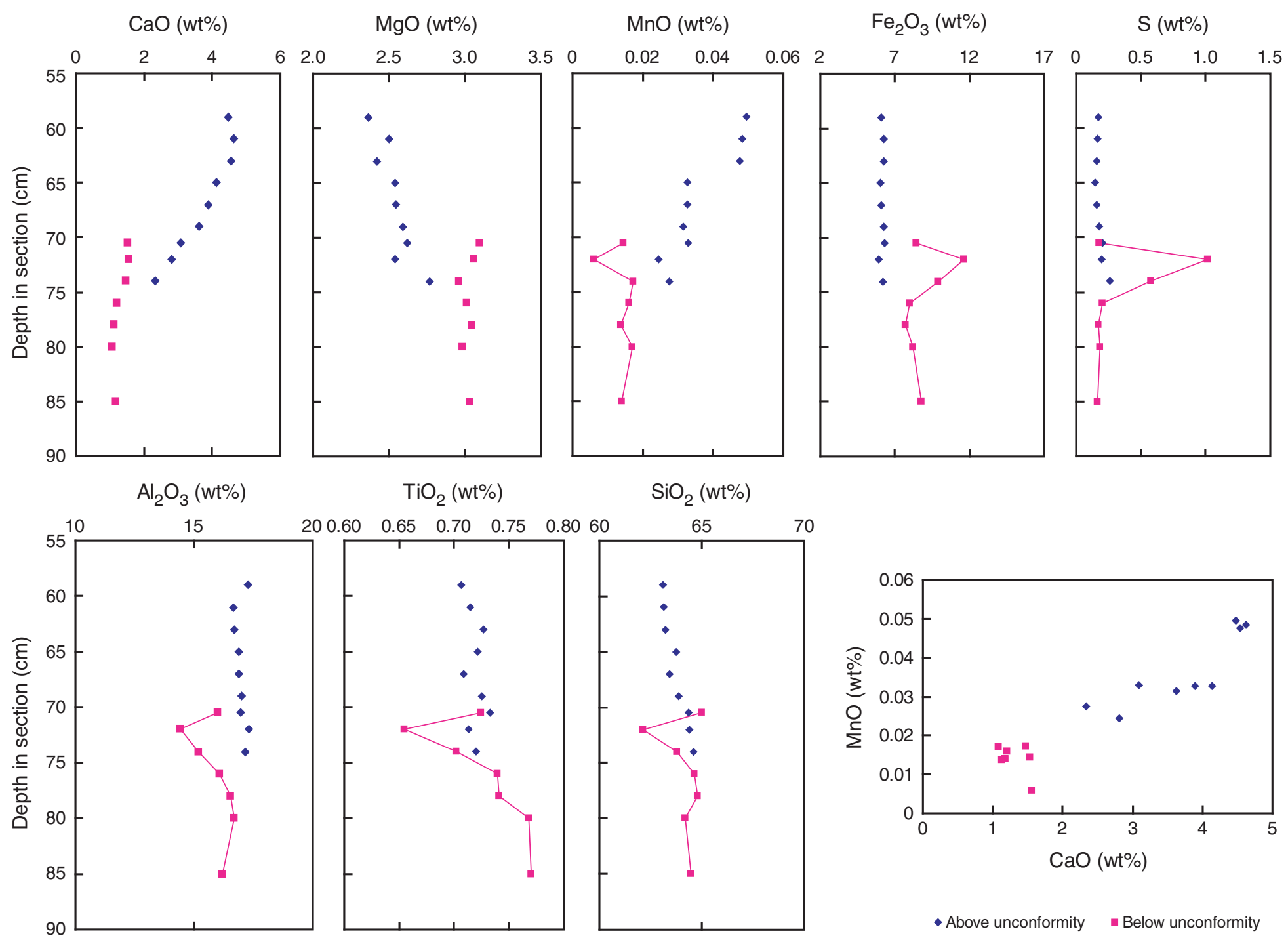

- Above unconformity - Below unconformity 
Figure F12. Comparison of XRF elemental analysis to core photograph and X-ray computed tomography (CT) image of CT-defined lithology Type 1. Elemental variations revealed by the XRF signal, most likely corresponding to variations in silt/clay ratio, are not reflected in either imaging mode (interval 316-C0004D-30R-1, 114-129 cm). Oxide weight percent by XRF scan.

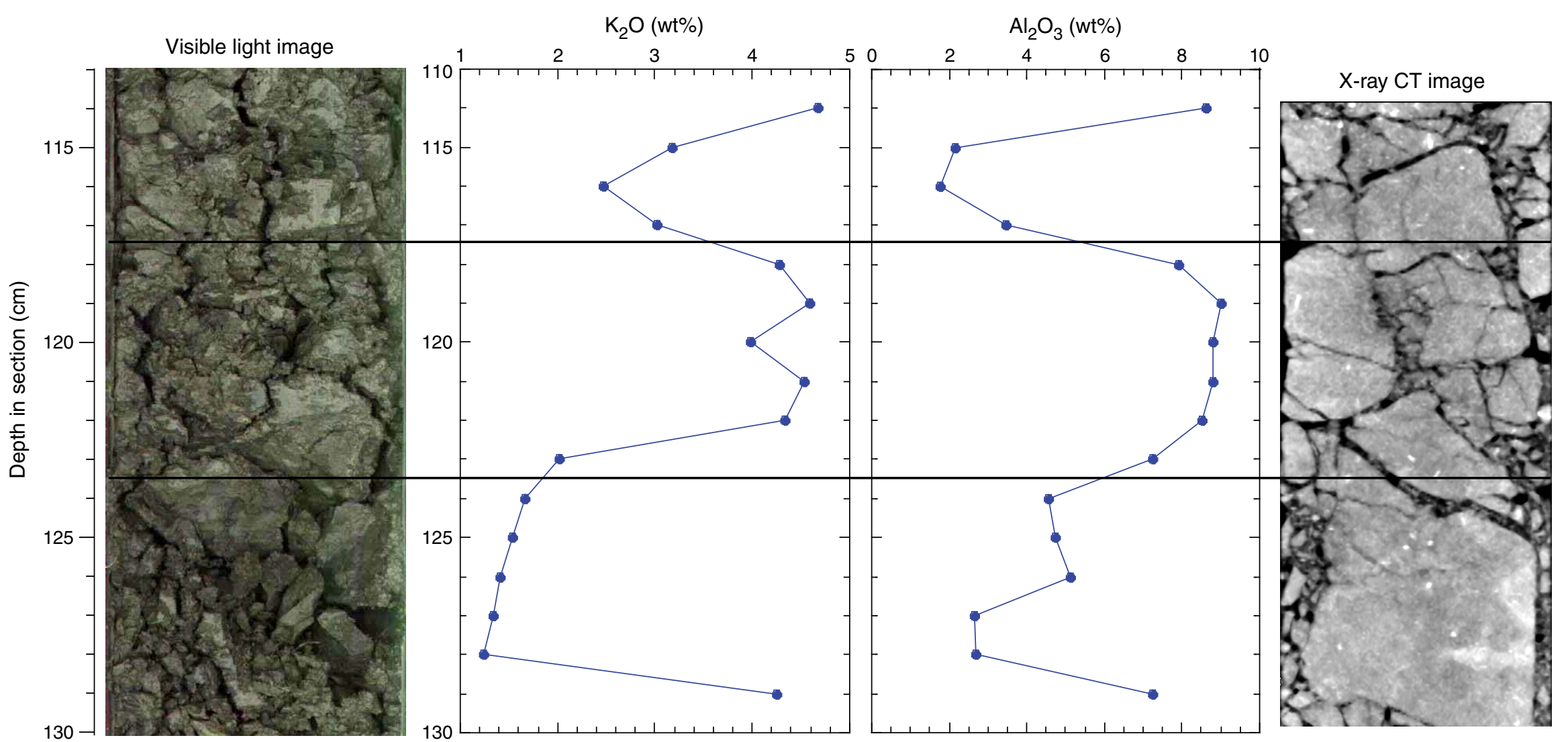




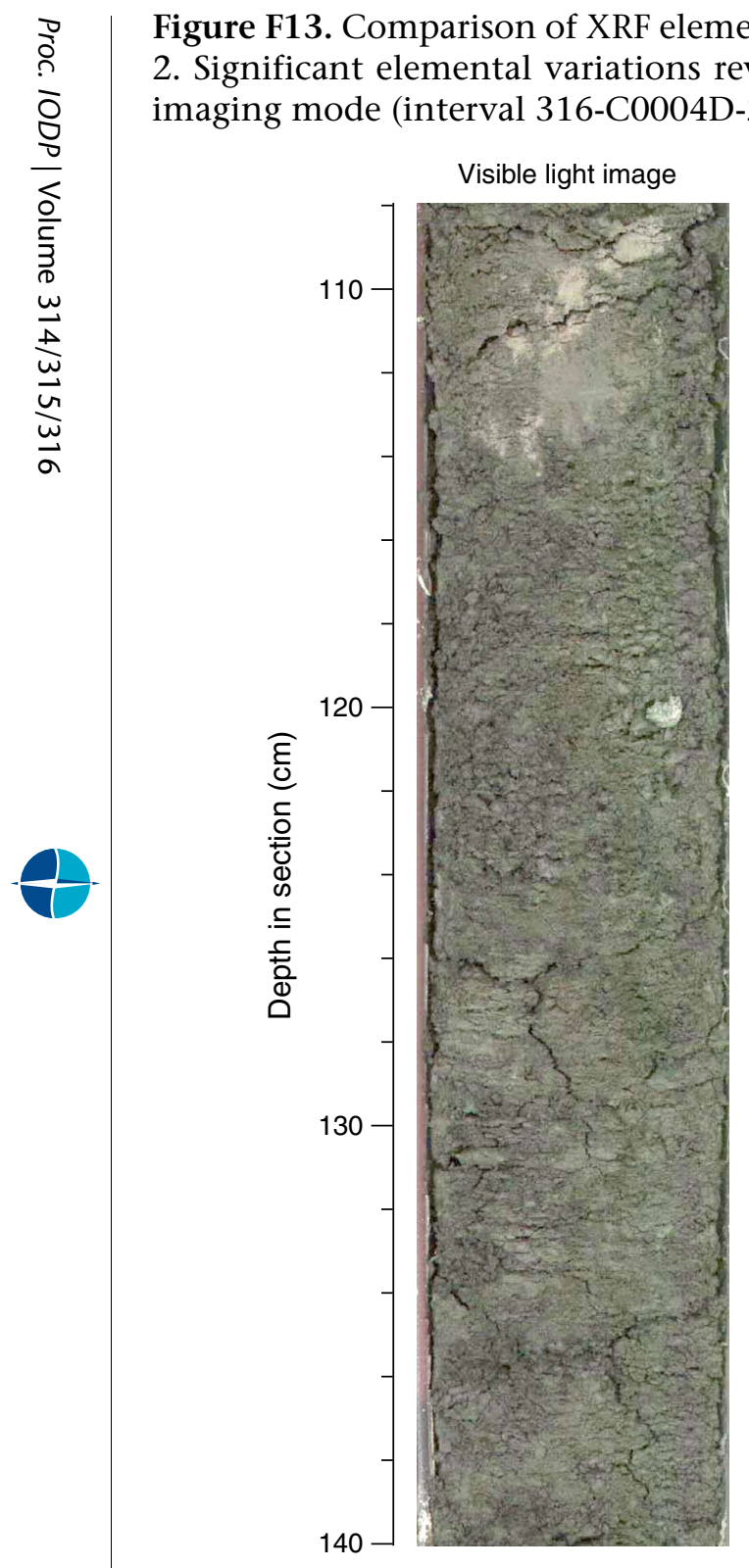

Figure F13. Comparison of XRF elemental analysis to core photograph and X-ray computed tomography (CT) image of CT-defined lithology Type 2. Significant elemental variations revealed by the XRF signal, most likely corresponding to variations in silt/clay ratio, not reflected in either imaging mode (interval 316-C0004D-29R-2, 108-140 cm). Oxide weight percent by XRF scan.
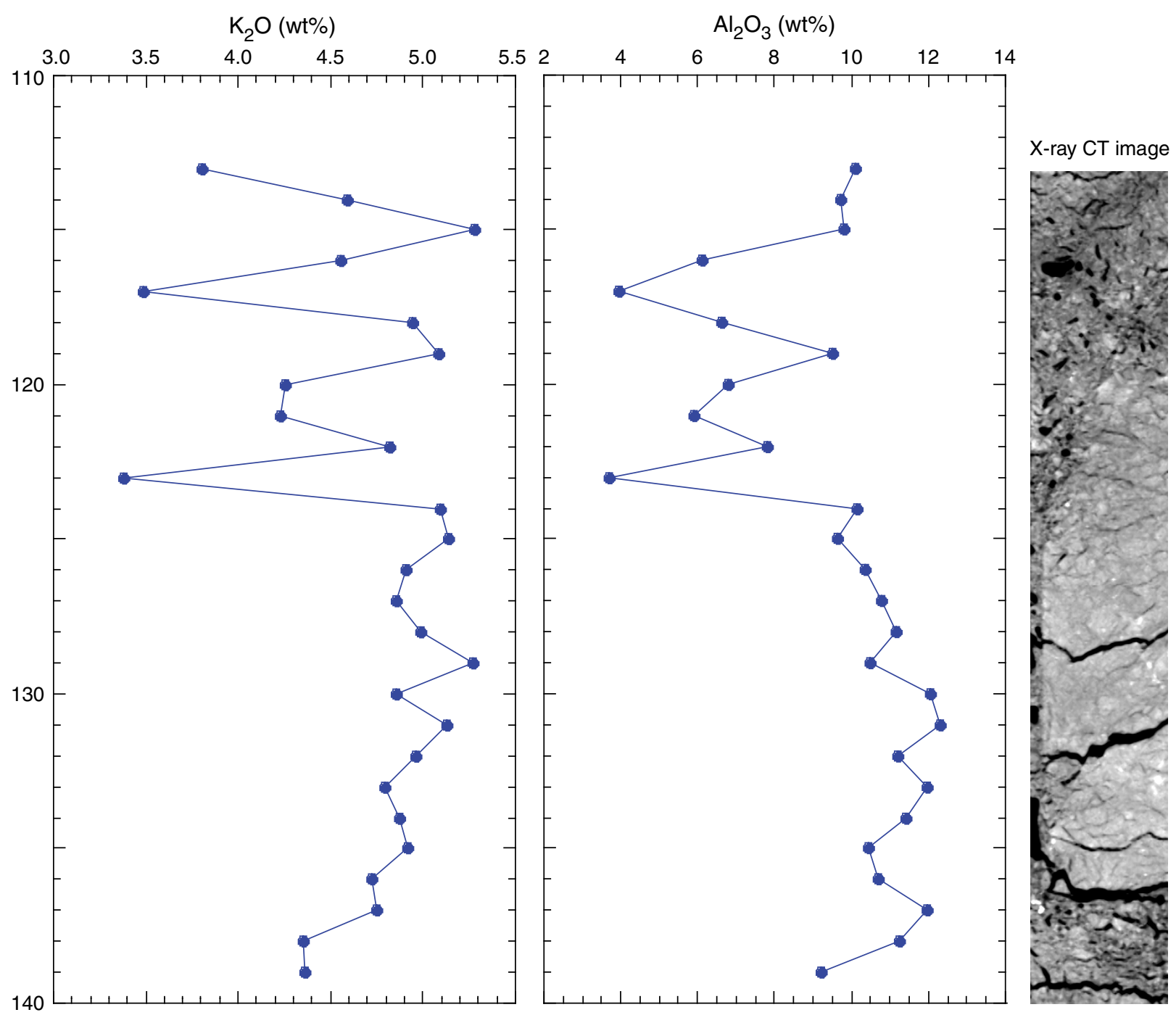
Figure F14. Sample log sheet used to record structural data and observations from working half of split core.

Structural Geology

\begin{tabular}{llll}
\hline Exp: & Site: & Core: & Observer: \\
\end{tabular}

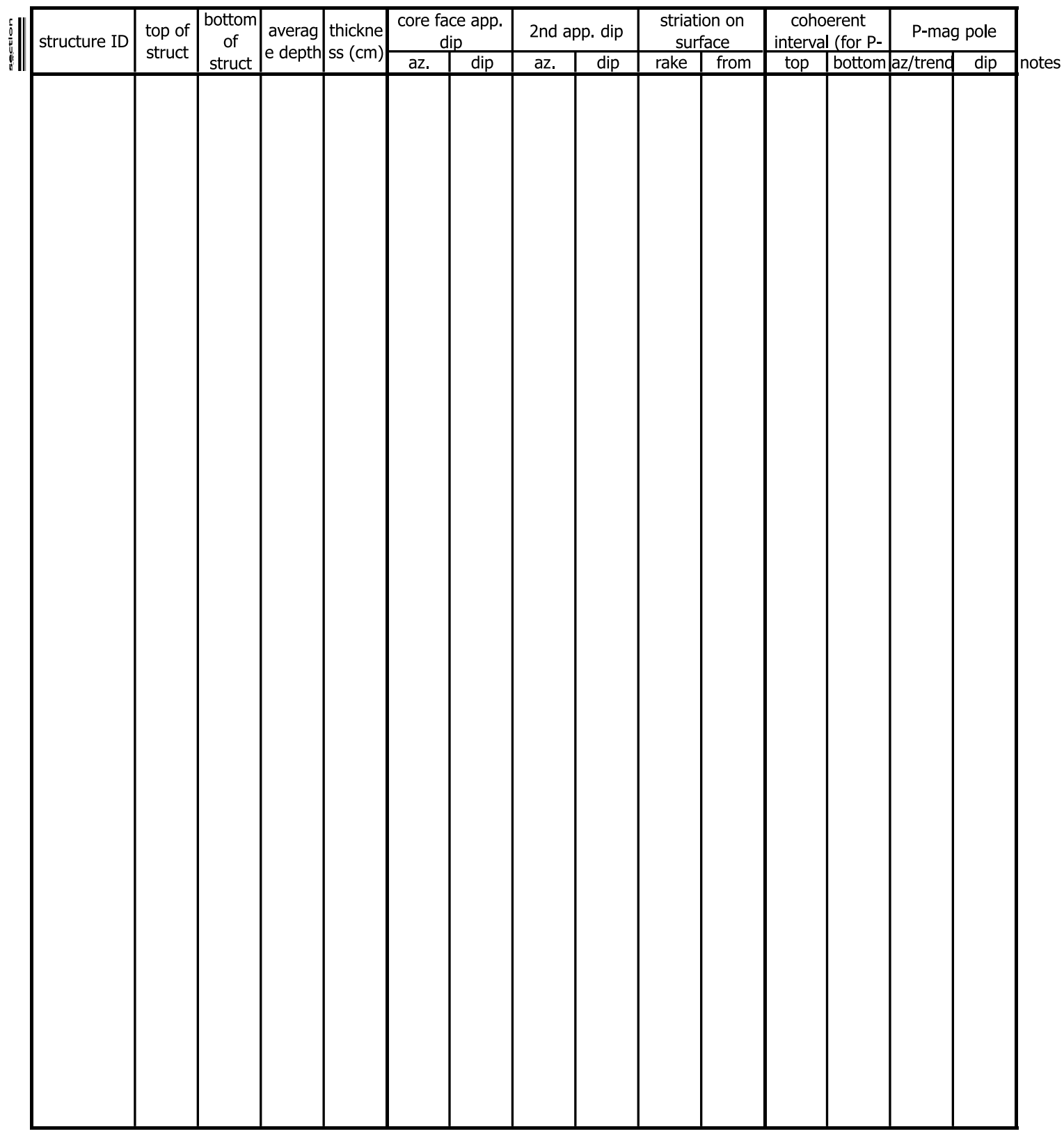


Figure F15. Modified protractor used to measure apparent dips, trends, plunges, and rakes on planar and linear features in a split core.

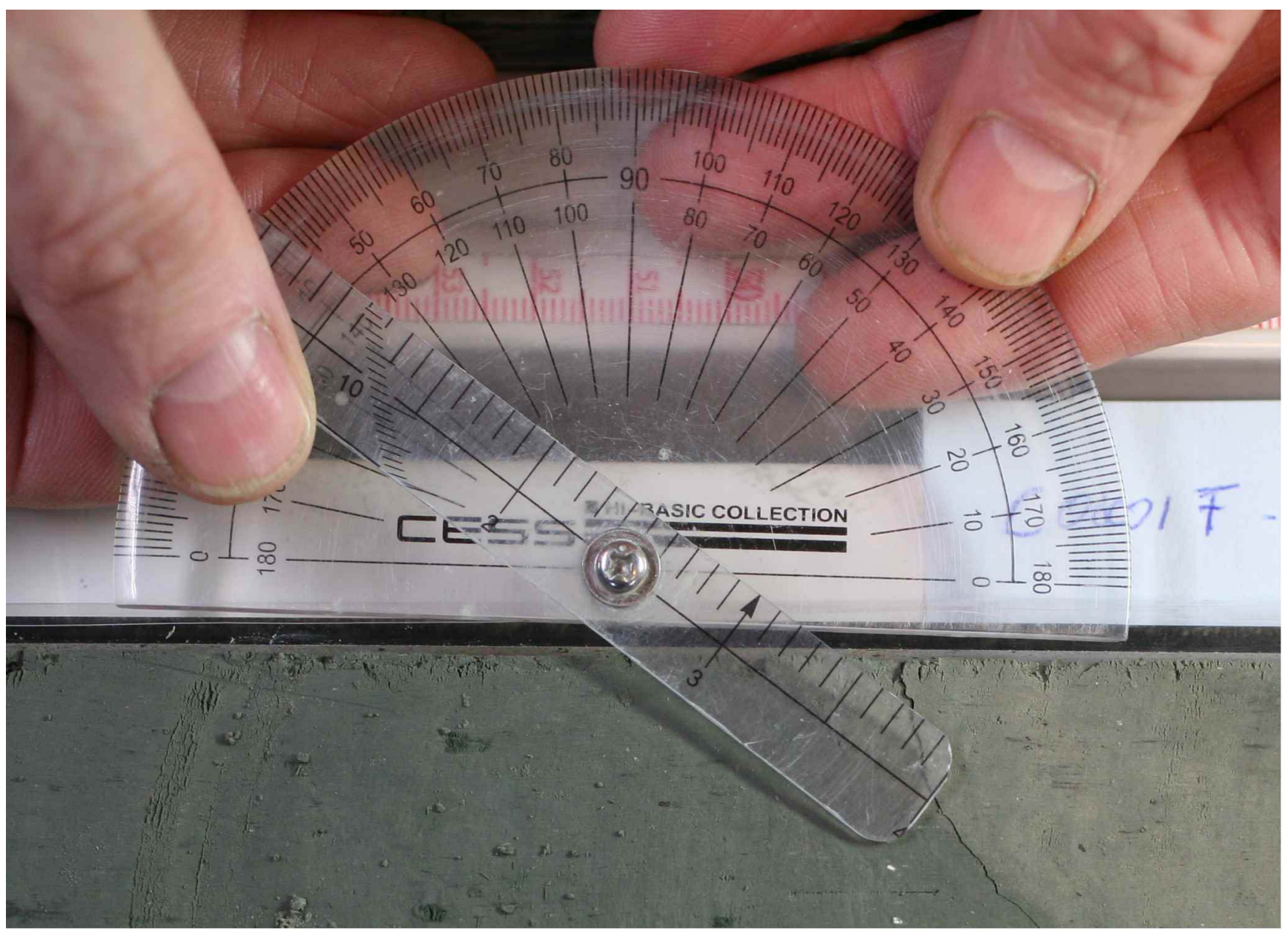


Figure F16. Core reference frame and $x-, y-, z$-coordinates used in orientation data calculations.

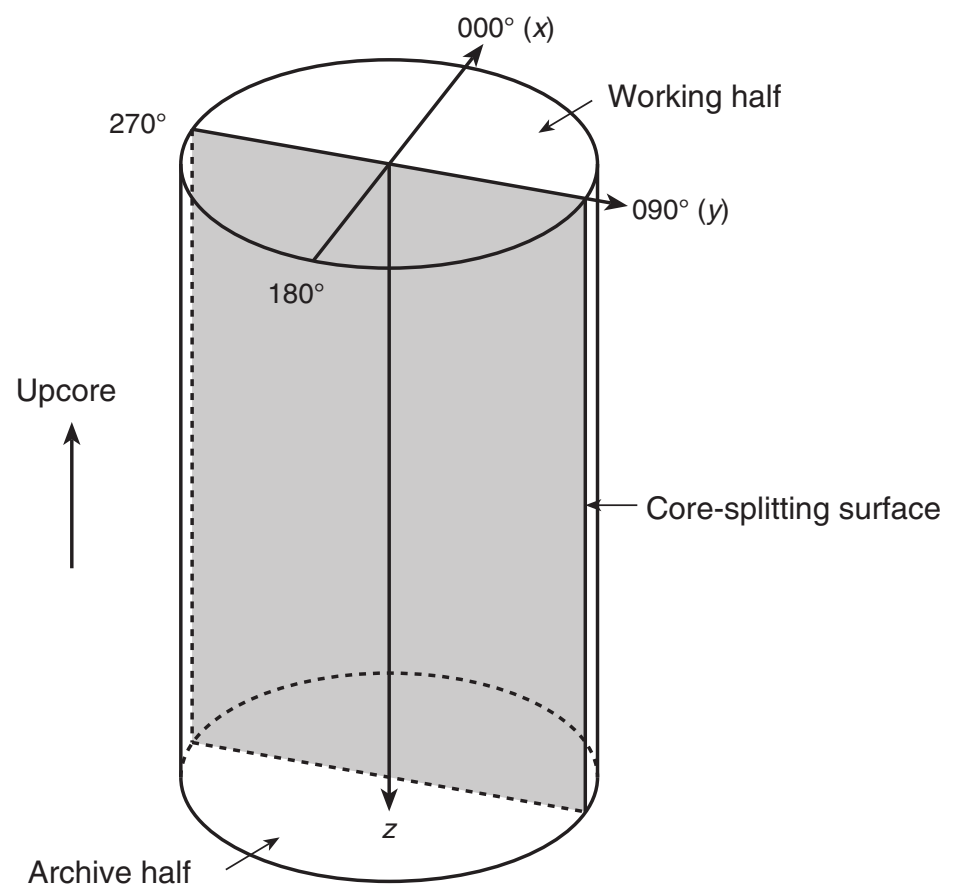


Figure F17. Spreadsheet used for recording and calculating orientation data.

\begin{tabular}{|c|c|c|c|c|c|c|c|c|c|c|c|c|c|c|c|c|c|c|c|c|c|c|}
\hline \multirow[b]{2}{*}{$\begin{array}{ll}0 \\
\overline{0} \\
\end{array}$} & \multirow{2}{*}{ structure ID } & \multirow{2}{*}{$\begin{array}{l}\text { top of } \\
\text { struct }\end{array}$} & \multirow{2}{*}{$\begin{array}{l}\text { bottom of } \\
\text { struct }\end{array}$} & \multirow{2}{*}{$\begin{array}{l}\text { average } \\
\text { depth }\end{array}$} & \multirow{2}{*}{$\begin{array}{l}\text { thickness } \\
(\mathrm{cm})\end{array}$} & \multicolumn{2}{|c|}{$\begin{array}{c}\text { core face app. } \\
\text { dip }\end{array}$} & \multicolumn{2}{|c|}{ 2nd app. dip } & \multicolumn{2}{|c|}{$\begin{array}{c}\text { striation on } \\
\text { surface }\end{array}$} & \multicolumn{5}{|c|}{ plane-normal orientation } & \multicolumn{3}{|c|}{$\begin{array}{l}\text { plane orientation } \\
\text { (RHR) }\end{array}$} & \multicolumn{3}{|c|}{ fault } \\
\hline & & & & & & $a z$ & dip & $a z$ & dip & rake & from & 1 & $\mathrm{~m}$ & $\mathrm{n}$ & $a z$ & dip & dip dir & strike & dip & csf rake & str rake & slip sense \\
\hline \multirow{19}{*}{ 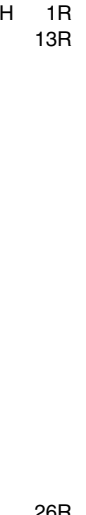 } & \begin{tabular}{l|l}
1 & \\
\end{tabular} & & & & & & & & & & & & & & & & & & & & & \\
\hline & 1 reverse fault & 124.0 & 140.5 & & $\leq 0.15$ & 270 & 78 & 341 & 0 & & & 0.32 & 0.92 & 0.20 & 71 & 11 & 251 & 161 & 79 & & 90 & 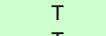 \\
\hline & 2 reverse fault & 0.0 & 9.0 & & $\leq 0.3$ & & & & & & & 0.00 & 0.00 & 0.00 & 90 & 0 & 270 & 180 & 90 & & 90 & T \\
\hline & 2 normal fault & 80.0 & 92.0 & & $\leq 0.2$ & 270 & 68 & 58 & 0 & & & -0.79 & 0.49 & 0.20 & 148 & 11 & 328 & 238 & 79 & & 90 & $\mathrm{~N}$ \\
\hline & 2 normal shear zone & 59.0 & 59.5 & & 0.50 & 90 & 4 & 0 & 0 & & & 0.00 & 0.07 & -1.00 & 90 & -86 & 90 & 0 & 4 & & 90 & $\mathrm{~N}$ \\
\hline & 2 bedding & 138.0 & 140.0 & & 0.50 & 90 & 5 & 180 & 5 & & & 0.09 & -0.09 & 0.99 & 315 & 83 & 135 & 45 & 7 & & & \\
\hline & 3 normal (?) fault & 16.5 & 26.0 & & 0.20 & 270 & 62 & 323 & 0 & & & 0.53 & 0.71 & 0.37 & 53 & 22 & 233 & 143 & 68 & & 90 & $\mathrm{~N}$ \\
\hline & 3 normal fault & 18.0 & 36.5 & & & 90 & 77 & 39 & 0 & 9 & 90 & -0.61 & 0.76 & -0.17 & 129 & -10 & 129 & 39 & 80 & 82 & 73 & $\mathrm{~N}$ \\
\hline & 3 shear band & 120.0 & 121.5 & & $\leq 0.1$ & 90 & 16 & 0 & 0 & 2 & 90 & 0.00 & 0.28 & -0.96 & 90 & -74 & 90 & 0 & 16 & 90 & 88 & \\
\hline & 3 normal (?) fault & 138.0 & 140.5 & & & 90 & 71 & 322 & 0 & & & 0.58 & 0.75 & -0.26 & 52 & -15 & 52 & 322 & 75 & & 90 & $\mathrm{~N}$ \\
\hline & 3 thrust & 135.0 & 139.5 & & & 270 & 38 & 180 & 12 & 7 & 270 & -0.16 & -0.60 & -0.77 & 255 & -50 & 255 & 165 & 40 & 102 & 109 & T \\
\hline & \begin{tabular}{l|l}
3 & fault
\end{tabular} & 137.5 & 139.0 & & & 90 & 10 & 180 & 3 & 7 & 270 & 0.05 & -0.17 & 0.98 & 287 & 80 & 107 & 17 & 10 & 74 & 81 & T \\
\hline & 4 normal (?) fault & 0.0 & 7.0 & & $\leq 0.3$ & 90 & 66 & 339 & 0 & & & 0.33 & 0.85 & -0.38 & 69 & -22 & 69 & 339 & 68 & & 90 & $\mathrm{~N}$ \\
\hline & 4 normal fault & 32.5 & 49.0 & & $\approx 0.1$ & 90 & 76 & 299 & 0 & 10 & 90 & 0.85 & 0.47 & -0.12 & 29 & -7 & 29 & 299 & 83 & 102 & 92 & $\mathrm{~N}$ \\
\hline & $\begin{array}{ll}6 & \text { thrust shear zone }\end{array}$ & 137.0 & 137.0 & & $\approx 0.1$ & 270 & 3 & 5 & 0 & & & 0.00 & 0.05 & 0.99 & 95 & 84 & 275 & 185 & 6 & & 90 & T \\
\hline & \begin{tabular}{l|l}
6 & shear zone
\end{tabular} & 138.0 & 138.0 & & & 270 & 2 & 2 & 0 & & & 0.00 & 0.03 & 1.00 & 92 & 87 & 272 & 182 & 3 & & & \\
\hline & $\begin{array}{ll}6 \text { web structure } \\
\end{array}$ & 138.0 & 140.5 & & & & & & & & & & & & & & & & & & & \\
\hline & 7 deformation band & 97.0 & 107.0 & & & 270 & 71 & 48 & 0 & & & -0.70 & 0.63 & 0.22 & 138 & 13 & 318 & 228 & 77 & & & \\
\hline & 7 deformation band & 97.0 & 107.0 & & & 270 & 90 & 0 & 0 & & & 0.00 & 1.00 & 0.00 & 90 & 0 & 270 & 180 & 90 & & & \\
\hline \multirow[t]{7}{*}{$26 \mathrm{R}$} & 1 Loose breccia & & & & & & & & & & & & & & & & & & & & & \\
\hline & ${ }^{2}$ Loose pleces & & & & & & & & & & & 0.00 & 0.00 & 0.00 & 90 & 0 & 270 & 180 & 90 & & & \\
\hline & & & & & & & & & & & & 0.00 & 0.00 & 0.00 & 90 & 0 & 270 & 180 & 90 & & & \\
\hline & & & & & & & & & & & & 0.00 & 0.00 & 0.00 & 90 & 0 & 270 & 180 & 90 & & & \\
\hline & & & & & & & & & & & & 0.00 & 0.00 & 0.00 & 90 & 0 & 270 & 180 & 90 & & & \\
\hline & & & & & & & & & & & & 0.00 & 0.00 & 0.00 & 90 & 0 & 270 & 180 & 90 & & & \\
\hline & & & & & & & & & & & & 0.00 & 0.00 & 0.00 & 90 & 0 & 270 & 180 & 90 & & & \\
\hline & & & & & & & & & & $\leq 90$ & $\begin{array}{l} \pm 1,90 \\
\text { top->"1" } \\
\text { bottom- }\end{array}$ & & & & & & & & & & Red me & ncert \\
\hline
\end{tabular}


Figure F18. Calculation of plane orientation (shaded) from two apparent dips. Intersections of split core surface and section perpendicular to split core surface and parallel to core direction with plane of interest are shown. $\left(\alpha_{1}, \beta_{1}\right)$ and $\left(\alpha_{2}, \beta_{2}\right)=$ azimuths and dips of traces of the plane on two sections, $v_{1}$ and $v_{2}=$ unit vectors parallel to traces of the plane on two sections, $v_{\mathrm{n}}=$ unit vector normal to plane.

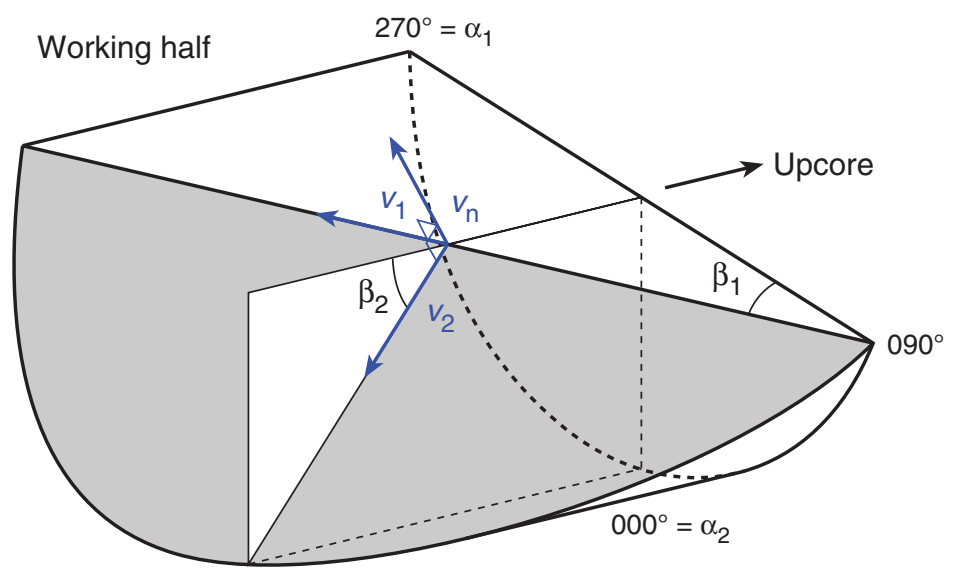


Figure F19. Dip direction $\left(\alpha_{d}\right)$, right-hand rule strike $\left(\alpha_{s}\right)$, and dip $(\beta)$ of a plane deduced from its normal azimuth $\left(\alpha_{n}\right)$ and dip $\left(\beta_{n}\right)$. A. $\beta_{n}<0^{\circ}$. B. $\beta_{n} \geq 0^{\circ} . v_{n}=$ unit vector normal to plane.
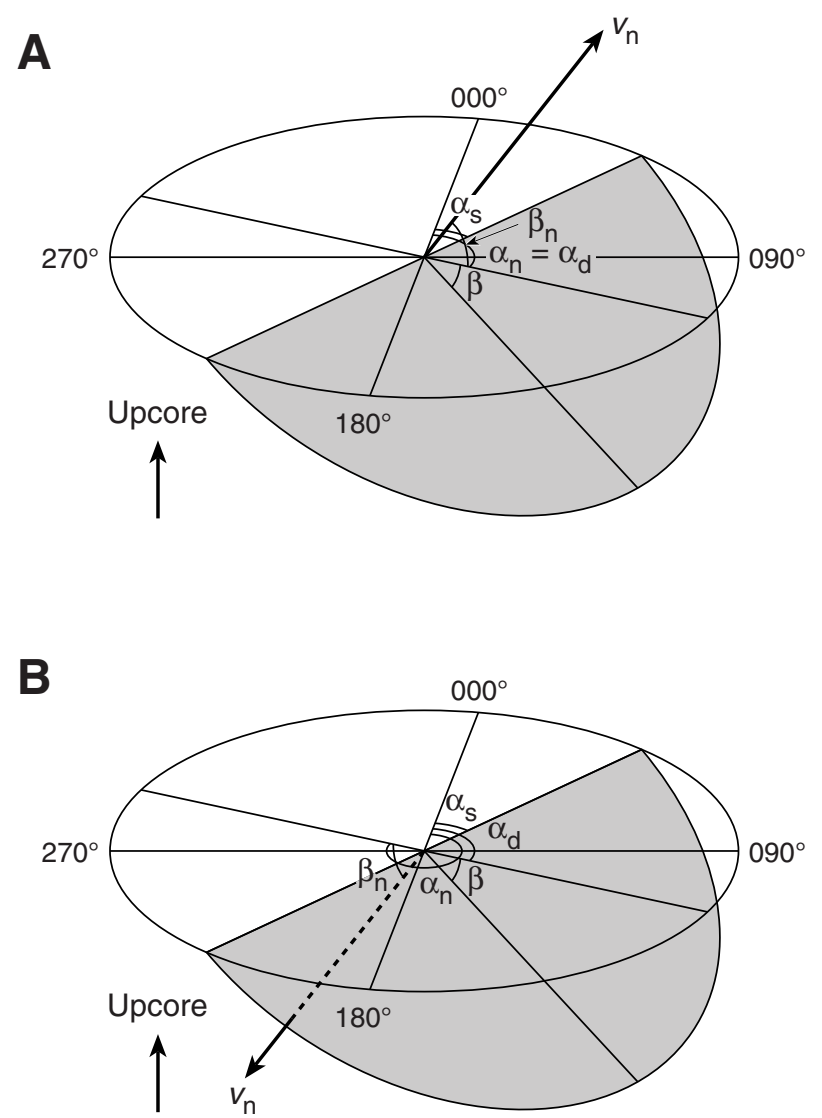
Figure F20. Apparent rake measurement of slickenlines on a fault surface from $270^{\circ}$ direction of split core surface trace. $\phi_{\mathrm{a}}=$ apparent rake, $v_{\mathrm{n}}=$ unit vector normal to fault plane, $v_{\mathrm{c}}=$ unit vector normal to split core surface, $v_{\mathrm{i}}=$ unit vector parallel to the intersection line between fault plane and split core surface.

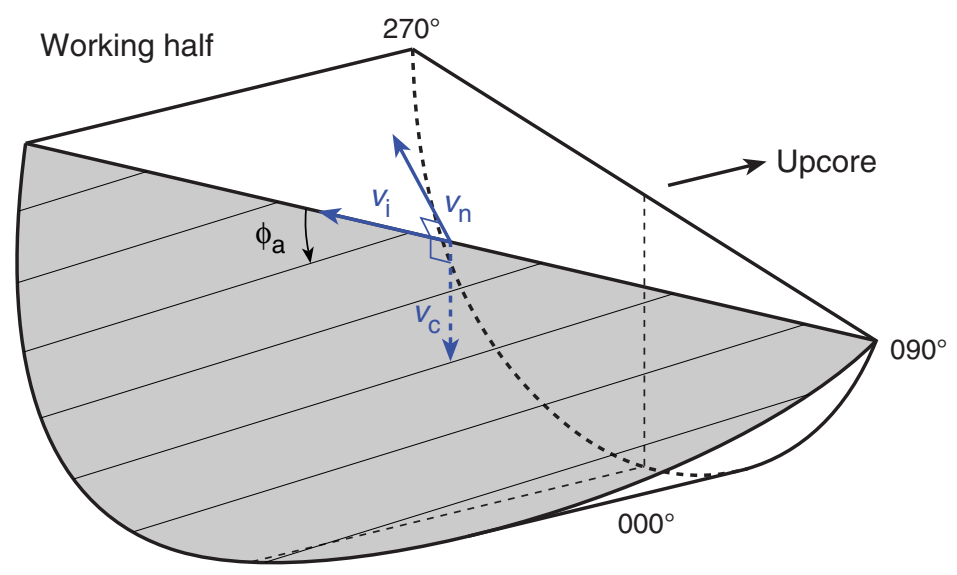


Figure F21. Rake of slickenlines $(\phi)$ deduced from the rake of intersection line between fault plane and split core surface $\left(\phi_{\mathrm{i}}\right)$ and apparent rake measured $\left(\phi_{\mathrm{a}}\right)$. A. $\phi_{\mathrm{a}}$ from top or $090^{\circ}$ direction when fault plane dips westward. B. $\phi_{a}$ from bottom or $090^{\circ}$ direction when fault plane dips eastward. C. $\phi_{a}$ from top or $270^{\circ}$ direction when fault plane dips eastward. D. $\phi_{a}$ from bottom or $270^{\circ}$ direction when fault plane dips westward. $\alpha_{s}=$ right-hand rule strike of fault plane, $v_{\mathrm{n}}=$ unit vector normal to fault plane, $v_{\mathrm{c}}=$ unit vector normal to split core surface, $v_{\mathrm{i}}$ $=$ unit vector parallel to intersection line between fault plane and split core surface, $v_{s}=$ horizontal unit vector in the right-hand rule strike direction of fault plane.
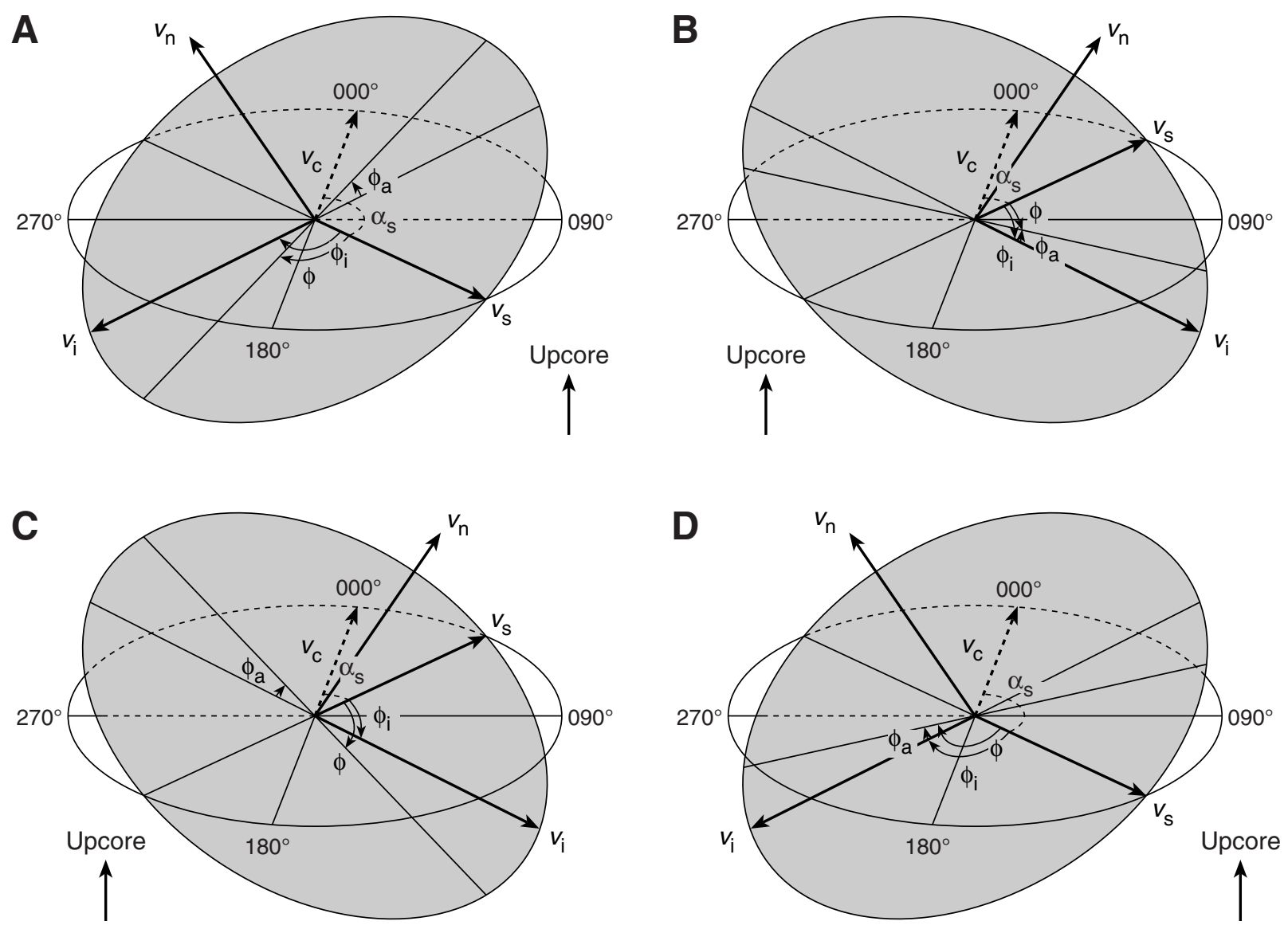
Figure F22. Azimuth correction based on paleomagnetic data. A. Paleomagnetic inclination $\beta_{p} \geq 0^{\circ}$. B. Paleomagnetic inclination $\beta_{p}<0^{\circ}$. $\alpha_{p}=$ paleomagnetic declination, $\alpha_{d}$ and $\alpha_{s}=$ dip direction and right-hand rule strike of a plane.
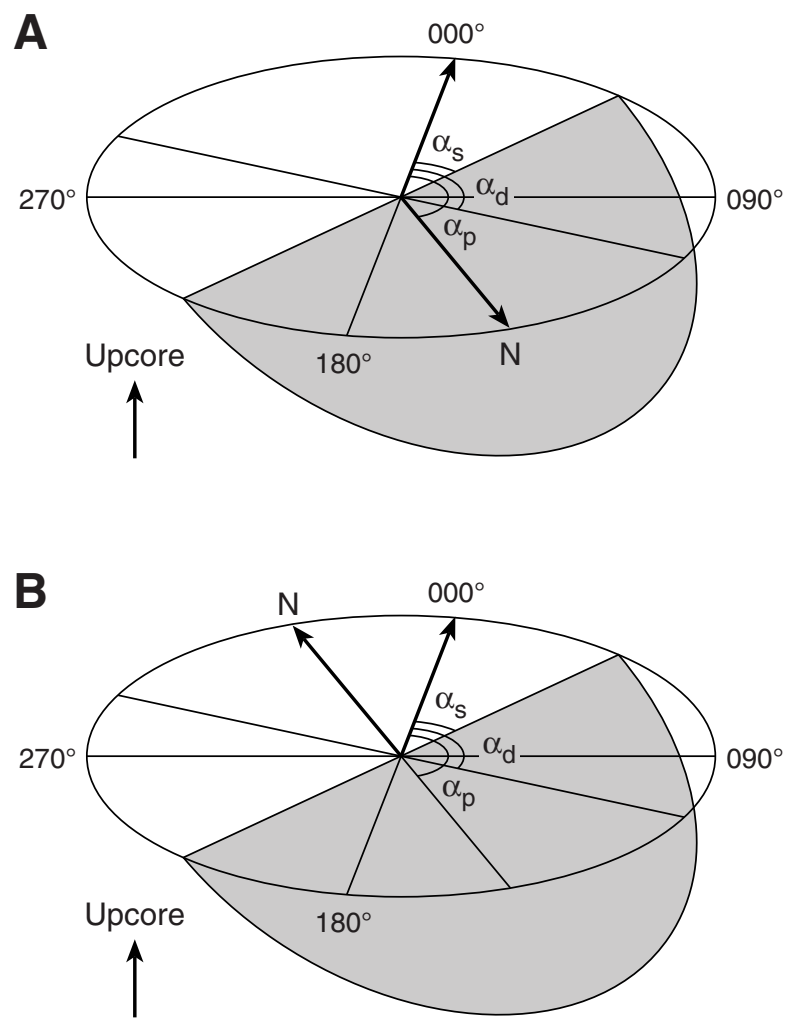
Figure F23. Structural geology window in J-CORES visual core description program. Fault data are entered in two ways: fault and slickenline data separately or fault data including slickenline parameters as a comment.

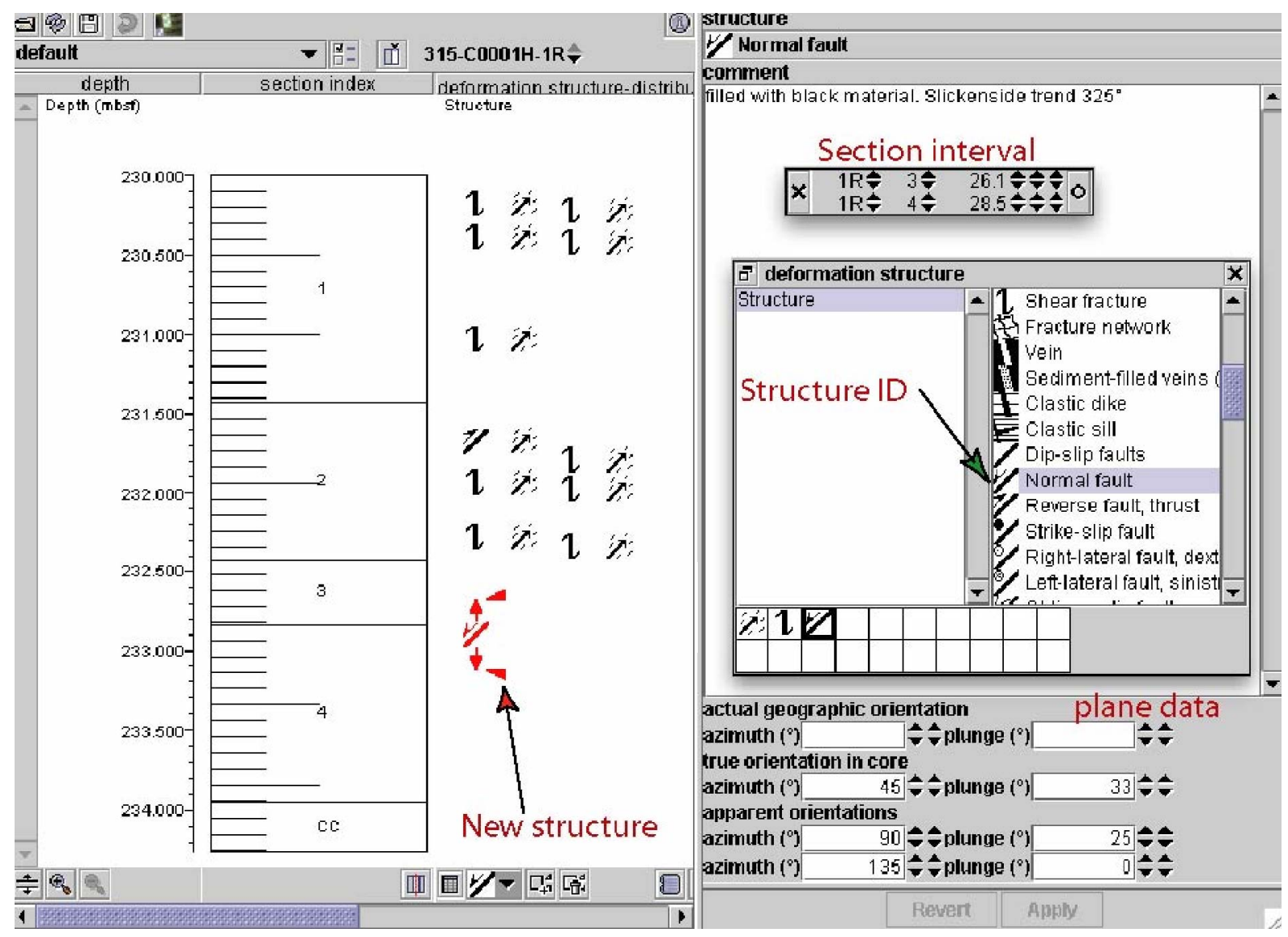


Figure F24. Structural geology symbols used in J-CORES original core description program.

Deformation structure

\begin{tabular}{ll}
$\because \vdots$ & Fault breccia \\
$\because$ & Fault gouge \\
J & Shear fracture \\
X & Sedint \\
$\equiv$ & Deformation bands \\
\hline & Fissility
\end{tabular}

I Clastic dike

/ Dip-slip faults

If Normal fault

Deverse fault, thrust

○ Strike-slip fault

○ Right lateral fault, dextral fault

$\oplus \quad$ Left lateral fault, sinistral fault 
Figure F25. Magnetostratigraphic and biostratigraphic events during Cenozoic era. $\mathrm{FO}=$ first occurrence, $\mathrm{LO}=$ last occurrence.

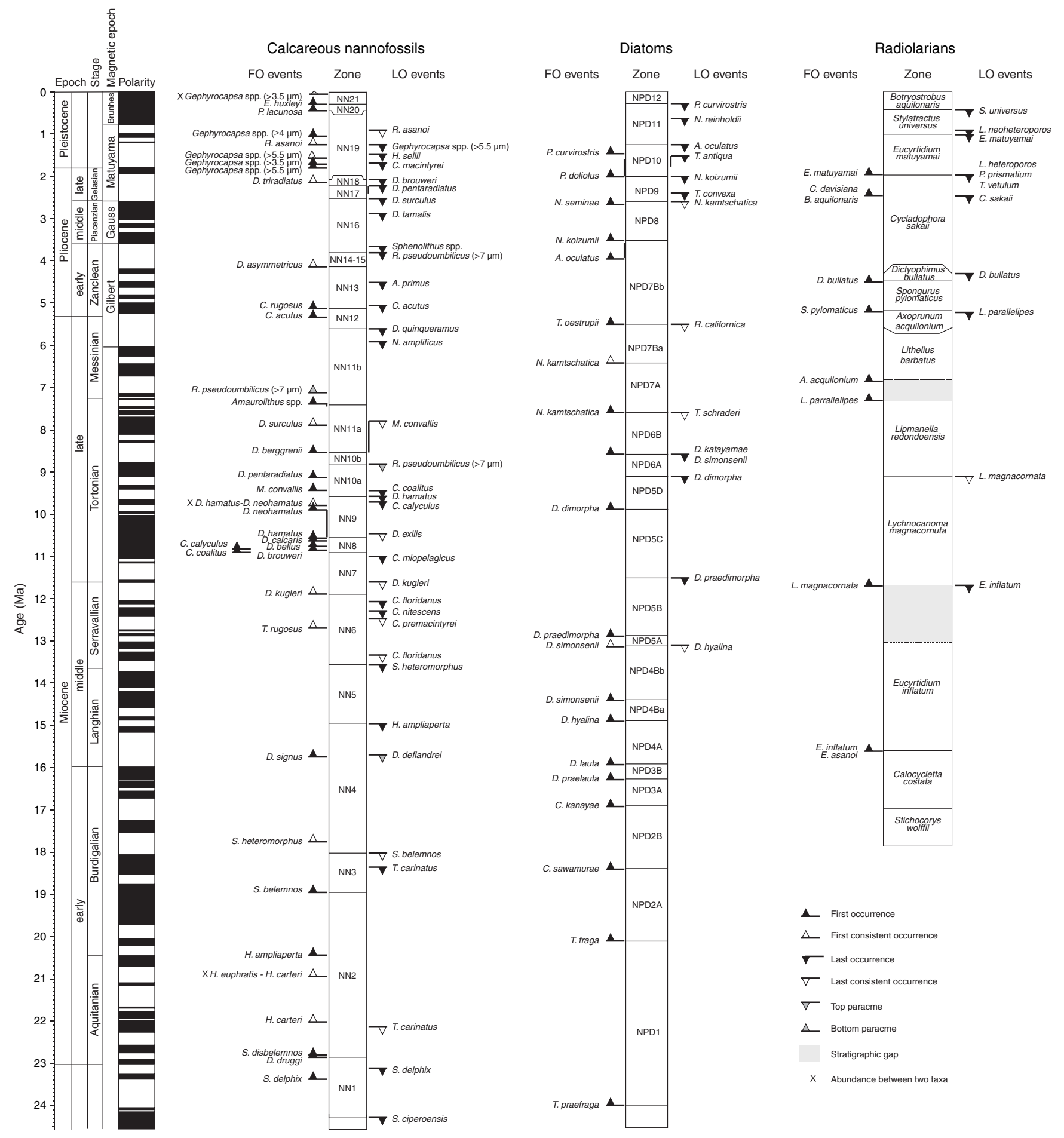


Figure F26. Sensor response of SQUID magnetometer with point source.

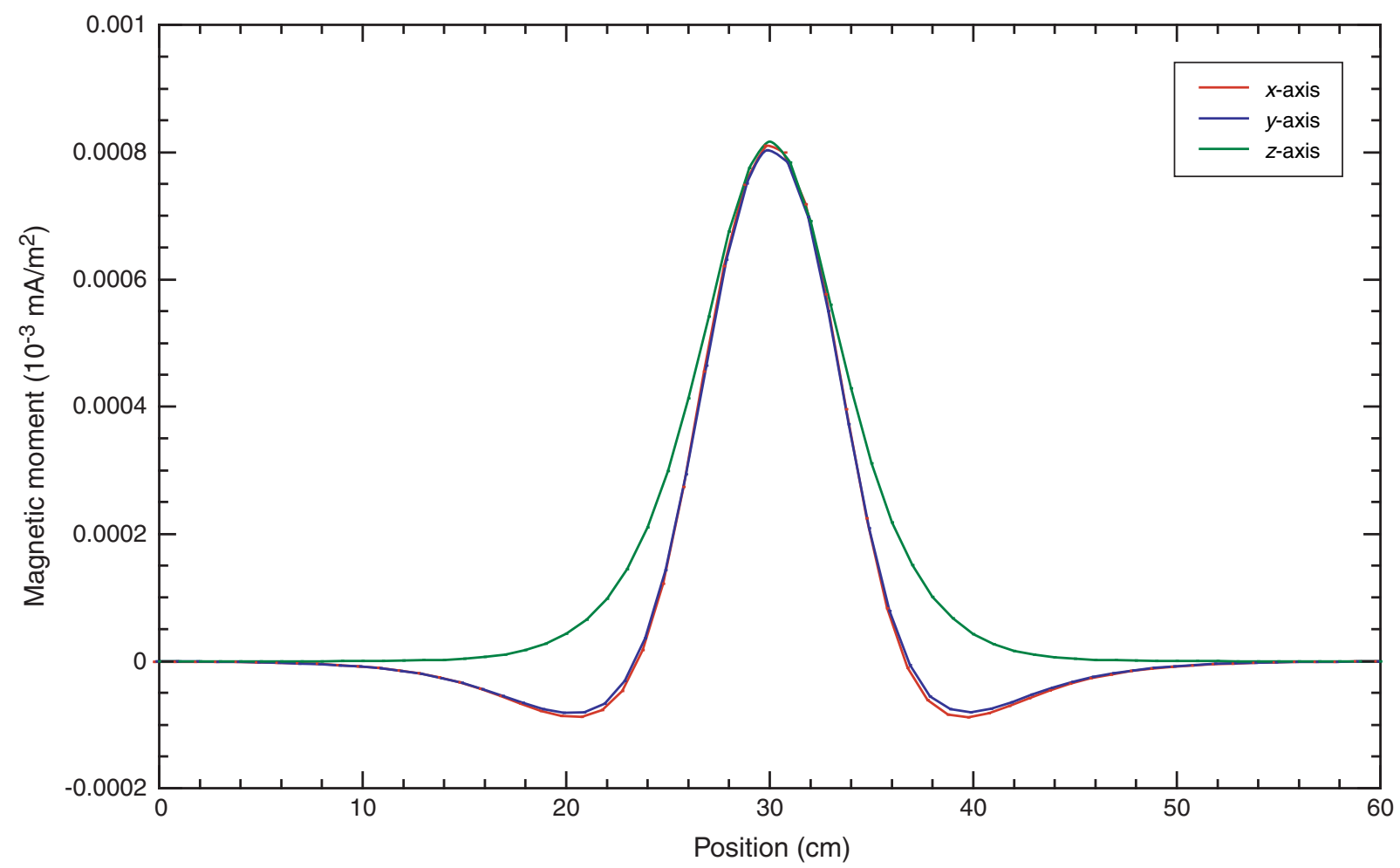


Figure F27. Orientation system used during Expedition 316. Coordinates for SRM (modified from Richter et al., 2007). SQUID = superconducting quantum interference device.

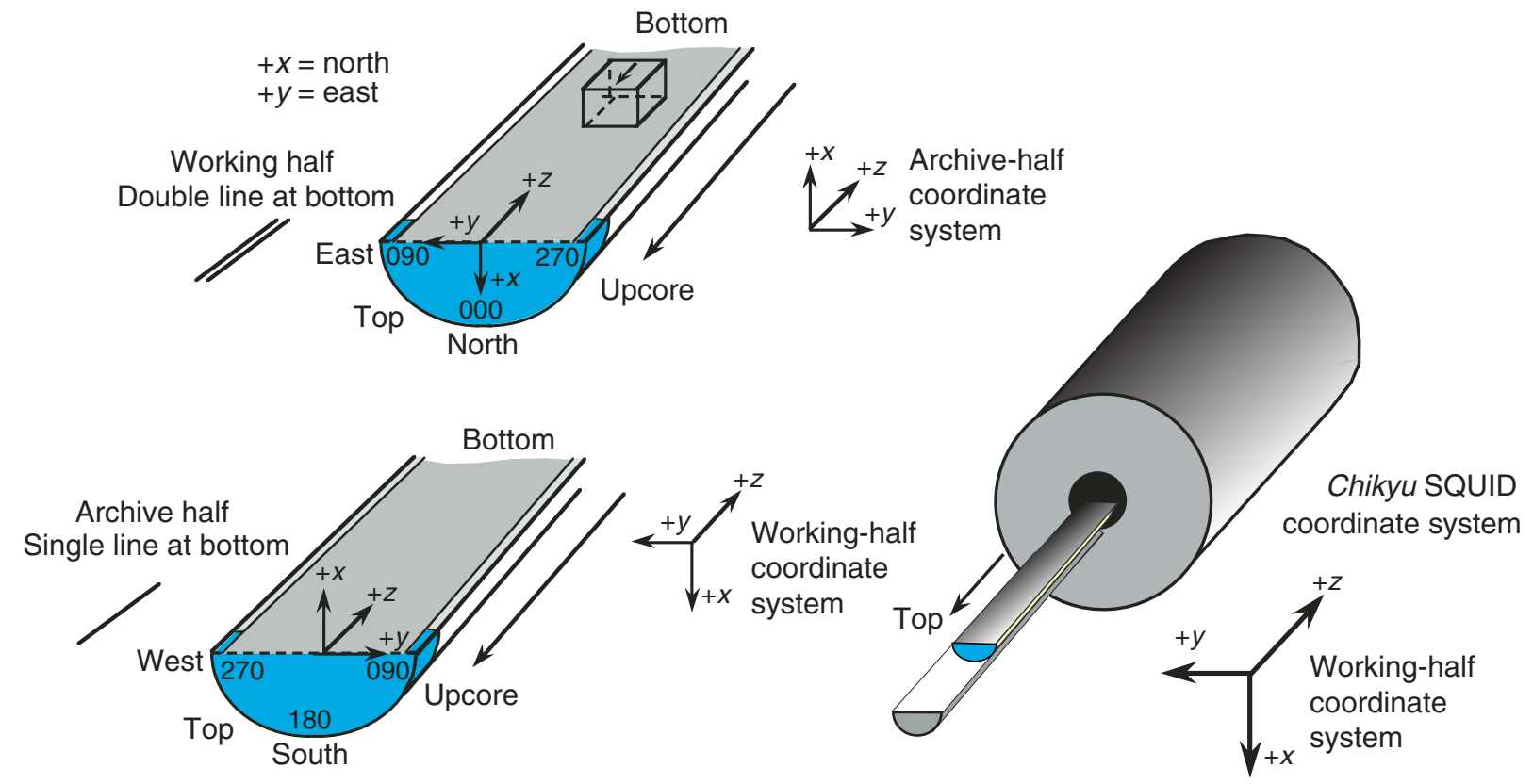


Figure F28. Effect of water evaporation on $P$-wave velocity at ambient conditions. Time is referenced to the time of electrical conductivity measurements. Temperature increased by $0.2^{\circ} \mathrm{C}$ during the measurements from $20.3^{\circ}$ to $20.5^{\circ} \mathrm{C}$. Relative humidity decreased by $1 \%$ during measurements from $33 \%$ to $32 \%$.

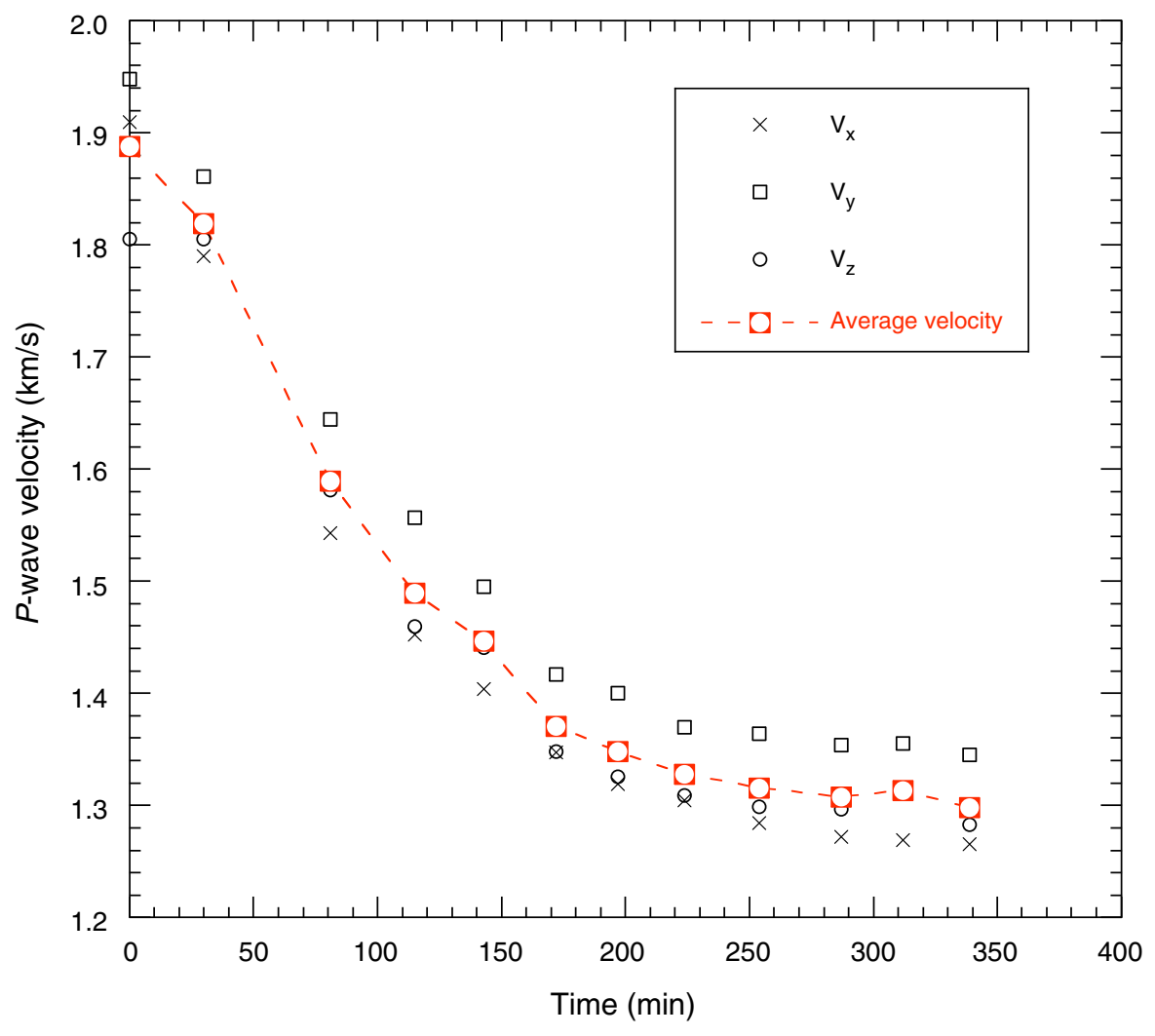


Figure F29. Measured and known thermal conductivities of (A) TeKa full-space needle (V10305), (B) TeKa halfspace plate (H10304), and (C) QTM-500 half-space plate. Calibration coefficients are listed here and in Table T13. Note that rubber $(0.517 \mathrm{~W} /[\mathrm{m} \cdot \mathrm{K}])$ and glass $(1.237 \mathrm{~W} /[\mathrm{m} \cdot \mathrm{K}])$ standards were loaned from M. Kinoshita, whereas other standards were onboard the Chikyu. Error bars = standard deviation of measurements. Best-fit line is also shown.
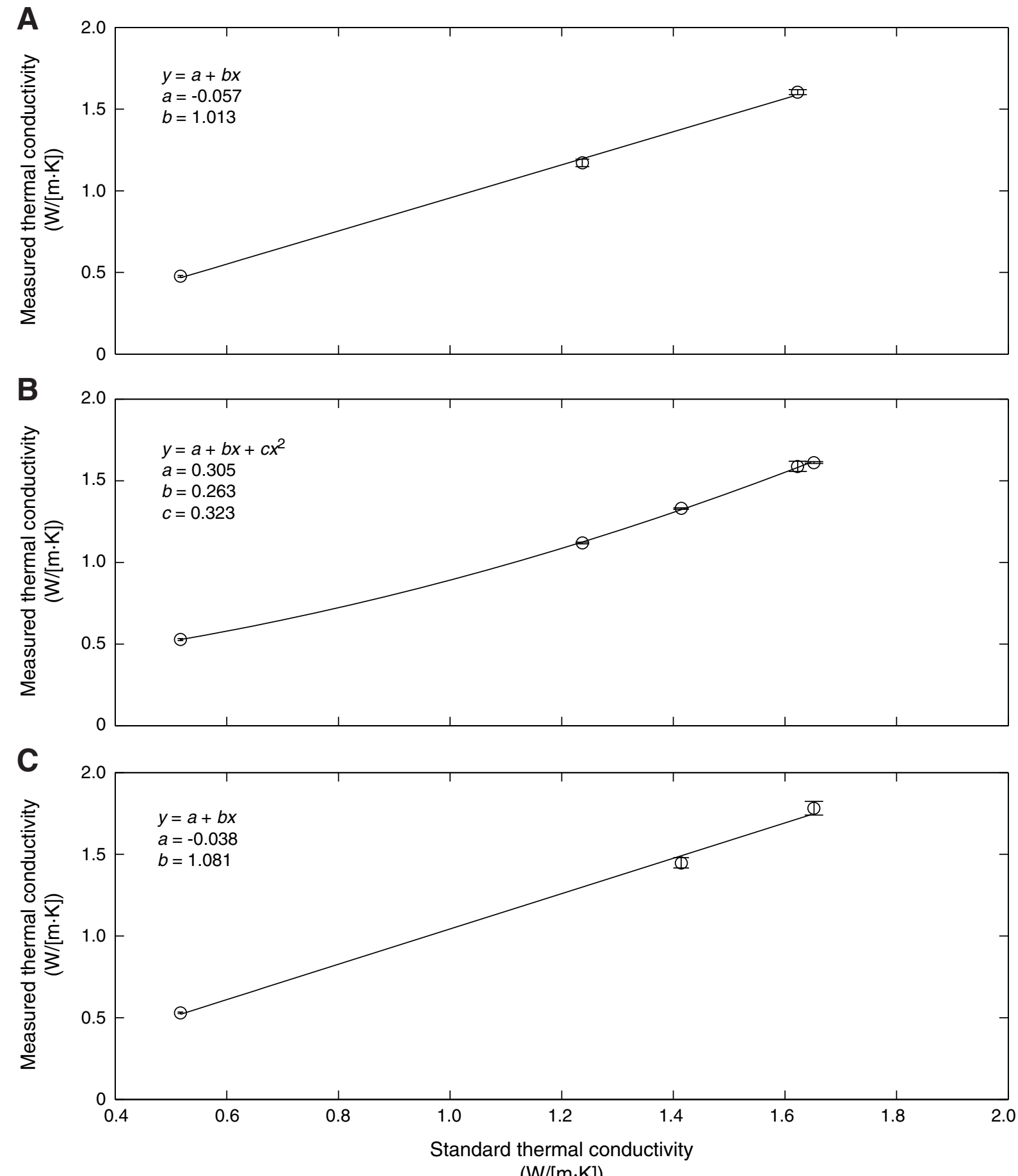

$(\mathrm{W} /[\mathrm{m} \cdot \mathrm{K}])$ 
Table T1. X-ray CT scanner settings used during Expedition 316. (See table notes.)

\begin{tabular}{|c|c|}
\hline Parameter & Setting \\
\hline Scan type & Helical-full-0.6 \\
\hline Pitch speed* & 0.625 \\
\hline Interval (mm) & 0.625 \\
\hline Gantry tilt $\left(^{\circ}\right)$ & S0.0 \\
\hline SFOV & Small \\
\hline Voltage (kV) & 120 \\
\hline Current (mA) & 100 \\
\hline Detector rows & 16 \\
\hline Helical thickness (mm) & 0.625 \\
\hline Pitch & $0.562: 1$ \\
\hline Speed ( $\mathrm{mm} /$ rotation) & 5.62 \\
\hline DFOV $(\mathrm{cm})$ & 9.6 \\
\hline $\mathrm{R} / \mathrm{L}$ center $(\mathrm{mm})$ & R0.0 \\
\hline $\mathrm{A} / \mathrm{P}$ center $(\mathrm{mm})$ & $\mathrm{A} 0.0$ \\
\hline Recon type & Detail \\
\hline Matrix type & 512 \\
\hline Recon option & Full \\
\hline Direct vis & Off \\
\hline
\end{tabular}

Notes: ${ }^{*}=$ relates the speed to the pitch. Protocol name: 9.6071129 for aluminum. SFOV $=$ scan field of view, DFOV $=$ dual field of view. R/L center $=$ distance right or left of the center line, $\mathrm{A} / \mathrm{P}$ center $=$ distance anterior or posterior of the center line.

Table T2. Characteristic X-ray diffraction peaks for semiquantitative analysis of composite clay minerals.

\begin{tabular}{lccl}
\hline \multicolumn{1}{c}{ Mineral } & Reflection & $\begin{array}{c}\text { d-value } \\
(\AA)\end{array}$ & $\begin{array}{c}\text { Peak position and } \\
\text { quantitation method } \\
\left({ }^{\circ} 2 \theta\right)\end{array}$ \\
\hline Composite clay & Multiple & 4.478 & $19.4-20.4$ (area) \\
Quartz & 100 & 4.257 & 20.9 (maximum intensity) \\
Cristobalite & 101 & 4.040 & 22.0 (maximum intensity) \\
Quartz & 101 & 3.342 & $26.3-27.0$ (area) \\
Plagioclase & 002 & 3.192 & $27.4-28.2$ (area) \\
Calcite & 104 & 3.035 & $29.1-29.7$ (area) \\
\hline
\end{tabular}

Table T3. Normalization factors for calculation of relative mineral abundance using bulk powder X-ray diffraction analysis. (See table note.)

\begin{tabular}{|c|c|c|c|c|}
\hline \multirow{2}{*}{$\begin{array}{l}\text { Affected mineral in } \\
\text { standard mixture: }\end{array}$} & \multicolumn{4}{|c|}{ Normalization factors } \\
\hline & Total clay & Quartz & Plagioclase & Calcite \\
\hline \multicolumn{5}{|l|}{ Influencing mineral: } \\
\hline Total clay & $9.8956702 \mathrm{E}-03$ & $-1.5889532 \mathrm{E}-04$ & $-2.8855808 \mathrm{E}-04$ & $-7.3842803 E-04$ \\
\hline Quartz & $-4.7221169 \mathrm{E}-05$ & $5.8782392 \mathrm{E}-04$ & $-4.7869325 \mathrm{E}-05$ & $-3.1098843 E-05$ \\
\hline Plagioclase & 7.2794763E-04 & $-4.2840613 \mathrm{E}-05$ & 1.3719777E-03 & $-3.6005495 E-05$ \\
\hline Calcite & $4.2042411 \mathrm{E}-05$ & $3.3021188 \mathrm{E}-06$ & $-4.1329499 \mathrm{E}-06$ & $1.3071455 \mathrm{E}-03$ \\
\hline
\end{tabular}

Note: Singular value deconvolution was used to compute the factors, following the procedure of Fisher and Underwood (1995). 
Table T4. Shipboard X-ray fluorescence powder results for standard JSd-2. (See table notes.)

\begin{tabular}{lrrrrrrrrrrr}
\hline \multicolumn{1}{c}{$\quad \mathrm{Sd}-2$} & $\mathrm{Na}_{2} \mathrm{O}$ & $\mathrm{MgO}$ & $\mathrm{Al}_{2} \mathrm{O}_{3}$ & \multicolumn{1}{c}{$\mathrm{SiO}_{2}$} & $\mathrm{P}_{2} \mathrm{O}_{5}$ & $\mathrm{~S}$ & $\mathrm{~K}_{2} \mathrm{O}$ & $\mathrm{CaO}$ & $\mathrm{TiO}_{2}$ & $\mathrm{MnO}$ & $\mathrm{Fe}_{2} \mathrm{O}_{3}$ \\
\hline Reference material value: & & & & & & & & & & & \\
$\quad$ Without S & 2.6 & 2.9 & 12.9 & 63.6 & 0.1 & - & 1.2 & 3.8 & 0.6 & 0.1 & 12.2 \\
With S & 2.5 & 2.8 & 12.7 & 62.7 & 0.1 & 1.4 & 1.2 & 3.8 & 0.6 & 0.1 & 12.0 \\
Average & 1.6 & 3.0 & 13.8 & 61.4 & 0.3 & 0.8 & 1.4 & 3.9 & 0.7 & 0.1 & 12.9 \\
Standard deviation (36, $\mathrm{N}=30)$ & 0.7 & 0.2 & 0.3 & 0.5 & 0.1 & 0.02 & 0.1 & 0.1 & 0.04 & 0.1 & 0.6 \\
Replicate analyses & 2.8 & 3.2 & 14.7 & 61.7 & 0.3 & 0.7 & 1.3 & 3.5 & 0.7 & 0.1 & 11.1 \\
& 2.4 & 3.2 & 14.5 & 61.5 & 0.3 & 0.7 & 1.3 & 3.6 & 0.7 & 0.1 & 11.6 \\
& 2.3 & 3.1 & 14.3 & 61.3 & 0.3 & 0.7 & 1.4 & 3.7 & 0.7 & 0.1 & 12.1 \\
& 1.7 & 3.0 & 14.2 & 62.3 & 0.3 & 0.7 & 1.3 & 3.7 & 0.7 & 0.1 & 11.9 \\
& 1.7 & 3.1 & 14.2 & 61.9 & 0.3 & 0.7 & 1.4 & 3.8 & 0.7 & 0.1 & 12.1 \\
\hline
\end{tabular}

Notes: $S=$ sulfur. $\sigma=$ standard deviation. $-=$ not applicable.

Table T5. X-ray fluorescence powder results for samples taken at the unconformity in Section 316-C0004C-9H-5. (See table note.)

\begin{tabular}{|c|c|c|c|c|c|c|c|c|c|c|c|c|}
\hline \multirow{2}{*}{$\begin{array}{l}\text { Core, section, } \\
\text { interval }(\mathrm{cm})\end{array}$} & \multirow{2}{*}{$\begin{array}{l}\text { Depth } \\
\text { CSF }(m)\end{array}$} & \multicolumn{11}{|c|}{ Major element (wt\%) } \\
\hline & & $\mathrm{Na}_{2} \mathrm{O}$ & $\mathrm{MgO}$ & $\mathrm{Al}_{2} \mathrm{O}_{3}$ & $\mathrm{SiO}_{2}$ & $\mathrm{P}_{2} \mathrm{O}_{5}$ & $S$ & $\mathrm{~K}_{2} \mathrm{O}$ & $\mathrm{CaO}$ & $\mathrm{TiO}_{2}$ & $\mathrm{MnO}$ & $\mathrm{Fe}_{2} \mathrm{O}_{3}$ \\
\hline \multicolumn{13}{|c|}{$\begin{array}{l}\text { 316-C0004C- } \\
\text { Above unconformity: }\end{array}$} \\
\hline $9 \mathrm{H}-5,58-60$ & 59.00 & 2.70 & 2.36 & 17.3 & 63.1 & 0.24 & 0.17 & 2.83 & 4.47 & 0.70 & 0.05 & 6.10 \\
\hline $9 \mathrm{H}-5,60-62$ & 61.00 & 2.71 & 2.50 & 16.7 & 63.1 & 0.26 & 0.17 & 2.90 & 4.63 & 0.71 & 0.05 & 6.27 \\
\hline $9 \mathrm{H}-5,62-64$ & 63.00 & 2.69 & 2.42 & 16.7 & 63.2 & 0.26 & 0.16 & 2.96 & 4.54 & 0.73 & 0.05 & 6.27 \\
\hline $9 \mathrm{H}-5,64-66$ & 65.00 & 2.55 & 2.54 & 16.9 & 63.7 & 0.26 & 0.14 & 2.93 & 4.14 & 0.72 & 0.03 & 6.04 \\
\hline $9 \mathrm{H}-5,66-68$ & 67.00 & 3.02 & 2.54 & 16.9 & 63.4 & 0.24 & 0.16 & 2.97 & 3.89 & 0.71 & 0.03 & 6.09 \\
\hline $9 \mathrm{H}-5,68-70$ & 69.00 & 2.48 & 2.59 & 17.0 & 63.9 & 0.23 & 0.18 & 3.00 & 3.63 & 0.73 & 0.03 & 6.28 \\
\hline $9 \mathrm{H}-5,70-71$ & 70.50 & 2.41 & 2.62 & 17.0 & 64.3 & 0.24 & 0.20 & 3.07 & 3.09 & 0.73 & 0.03 & 6.31 \\
\hline $9 \mathrm{H}-5,71-73$ & 72.00 & 2.91 & 2.54 & 17.3 & 64.4 & 0.22 & 0.20 & 2.97 & 2.81 & 0.71 & 0.02 & 5.94 \\
\hline $9 \mathrm{H}-5,73-75$ & 74.00 & 2.71 & 2.77 & 17.1 & 64.6 & 0.25 & 0.26 & 3.02 & 2.33 & 0.72 & 0.03 & 6.18 \\
\hline \multicolumn{13}{|c|}{ Below unconformity: } \\
\hline $9 \mathrm{H}-5,70-71$ & 70.50 & 1.88 & 3.10 & 16.0 & 65.0 & 0.25 & 0.18 & 2.91 & 1.53 & 0.72 & 0.01 & 8.42 \\
\hline $9 \mathrm{H}-5,71-73$ & 72.00 & 2.53 & 3.06 & 14.4 & 62.1 & 0.25 & 1.02 & 2.73 & 1.55 & 0.65 & 0.01 & 11.65 \\
\hline $9 \mathrm{H}-5,73-75$ & 74.00 & 2.25 & 2.96 & 15.2 & 63.8 & 0.23 & 0.58 & 2.91 & 1.48 & 0.70 & 0.02 & 9.88 \\
\hline $9 \mathrm{H}-5,75-77$ & 76.00 & 2.75 & 3.01 & 16.1 & 64.6 & 0.27 & 0.20 & 3.12 & 1.21 & 0.74 & 0.02 & 7.97 \\
\hline $9 \mathrm{H}-5,77-79$ & 78.00 & 2.46 & 3.05 & 16.5 & 64.8 & 0.27 & 0.17 & 3.18 & 1.13 & 0.74 & 0.01 & 7.69 \\
\hline $9 \mathrm{H}-5,79-81$ & 80.00 & 2.29 & 2.98 & 16.7 & 64.2 & 0.27 & 0.18 & 3.35 & 1.08 & 0.77 & 0.02 & 8.19 \\
\hline $9 \mathrm{H}-5,81-89$ & 85.00 & 1.79 & 3.03 & 16.2 & 64.5 & 0.26 & 0.16 & 3.35 & 1.17 & 0.77 & 0.01 & 8.79 \\
\hline
\end{tabular}

Note: $\mathrm{CSF}=$ core depth below seafloor. 
Table T6. X-ray fluorescence (XRF) powder results. (See table notes.)

\begin{tabular}{|c|c|c|c|c|c|c|c|c|c|c|c|c|}
\hline \multirow{2}{*}{$\begin{array}{l}\text { Hole, core, section, } \\
\text { interval }(\mathrm{cm})\end{array}$} & \multirow{2}{*}{$\begin{array}{l}\text { Depth } \\
\text { CSF }(m)\end{array}$} & \multicolumn{11}{|c|}{ Major element (wt\%) } \\
\hline & & $\mathrm{Na}_{2} \mathrm{O}$ & $\mathrm{MgO}$ & $\mathrm{Al}_{2} \mathrm{O}_{3}$ & $\mathrm{SiO}_{2}$ & $\mathrm{P}_{2} \mathrm{O}_{5}$ & $S$ & $\mathrm{~K}_{2} \mathrm{O}$ & $\mathrm{CaO}$ & $\mathrm{TiO}_{2}$ & $\mathrm{MnO}$ & $\mathrm{Fe}_{2} \mathrm{O}_{3}$ \\
\hline \multicolumn{13}{|l|}{ 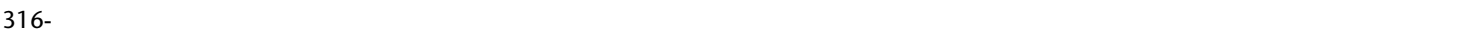 } \\
\hline C0006E-11H-1, 79-81 & 65.47 & 2.97 & 2.95 & 16.7 & 63.5 & 0.45 & 0.15 & 2.81 & 1.85 & 0.83 & 0.04 & 7.80 \\
\hline C0006E-20X-2, 121.5-123 & 127.97 & 2.56 & 2.87 & 17.4 & 63.9 & 0.31 & 0.21 & 3.24 & 1.58 & 0.79 & 0.05 & 7.14 \\
\hline C0006E-20X-3, 0-1.5 & 128.17 & 2.73 & 2.90 & 17.1 & 64.1 & 0.33 & 0.27 & 3.03 & 2.09 & 0.76 & 0.05 & 6.70 \\
\hline C0006F-23X-1, 65-66.5 & 154.49 & 2.27 & 2.96 & 16.6 & 63.6 & 0.40 & 0.22 & 2.89 & 2.70 & 0.79 & 0.06 & 7.51 \\
\hline C0006F-23X-3, 67-68.5 & 157.32 & 1.89 & 2.55 & 16.6 & 64.7 & 0.34 & 0.15 & 3.23 & 1.83 & 0.84 & 0.05 & 7.84 \\
\hline C0006E-25X-5, 82-83 & 179.28 & 2.83 & 2.80 & 16.8 & 63.6 & 0.31 & 0.22 & 2.88 & 2.23 & 0.79 & 0.07 & 7.43 \\
\hline C0006E-27X-1, 60-61.5 & 192.44 & 2.28 & 2.70 & 17.2 & 63.8 & 0.24 & 0.28 & 2.91 & 2.76 & 0.81 & 0.05 & 6.99 \\
\hline C0006E-27X-3, 113-115 & 195.80 & 2.09 & 2.92 & 16.7 & 63.5 & 0.38 & 0.22 & 2.90 & 2.83 & 0.83 & 0.05 & 7.62 \\
\hline C0006E-28X-1, 31-32.5 & 201.65 & 2.29 & 2.88 & 16.3 & 63.6 & 0.39 & 0.22 & 2.87 & 2.69 & 0.85 & 0.05 & 7.88 \\
\hline C0006E-29X-2, 84.5-86 & 213.11 & 2.46 & 2.78 & 17.3 & 63.9 & 0.28 & 0.25 & 2.86 & 2.28 & 0.78 & 0.05 & 7.08 \\
\hline C0006F-29X-2, 126-128 & 213.53 & 2.36 & 2.85 & 16.6 & 64.6 & 0.30 & 0.16 & 2.96 & 1.84 & 0.85 & 0.04 & 7.45 \\
\hline C0006E-29X-7, 0-1.5 & 219.05 & 2.34 & 2.75 & 16.8 & 63.5 & 0.29 & 0.26 & 3.02 & 2.37 & 0.84 & 0.06 & 7.80 \\
\hline C0006E-30X-1, 107-108.5 & 221.41 & 2.15 & 2.87 & 17.1 & 64.9 & 0.26 & 0.29 & 2.75 & 2.20 & 0.76 & 0.05 & 6.67 \\
\hline C0006E-32X-5, 23-24.5 & 243.83 & 2.05 & 2.80 & 16.9 & 64.6 & 0.27 & 0.25 & 2.95 & 2.09 & 0.81 & 0.04 & 7.19 \\
\hline C0006E-34X-2, 115-117 & 260.90 & 2.21 & 2.77 & 16.7 & 63.4 & 0.30 & 0.25 & 2.92 & 2.79 & 0.82 & 0.05 & 7.79 \\
\hline C0006E-34X-3, 94-95.5 & 262.10 & 2.38 & 2.67 & 16.9 & 63.8 & 0.32 & 0.26 & 2.81 & 2.60 & 0.80 & 0.05 & 7.38 \\
\hline C0006E-34X-4, 44-45.5 & 263.02 & 2.05 & 2.75 & 16.6 & 64.4 & 0.31 & 0.27 & 2.92 & 2.63 & 0.79 & 0.04 & 7.22 \\
\hline C0006E-34X-5, 0-1.5 & 263.62 & 2.36 & 2.61 & 17.0 & 64.9 & 0.28 & 0.22 & 2.94 & 2.02 & 0.80 & 0.04 & 6.85 \\
\hline C0006E-36X-1, 125-127 & 278.59 & 2.52 & 2.57 & 17.1 & 64.0 & 0.26 & 0.23 & 2.99 & 2.12 & 0.79 & 0.05 & 7.31 \\
\hline C0006E-36X-4, 0-1.5 & 281.56 & 2.57 & 3.00 & 16.8 & 63.7 & 0.28 & 0.27 & 2.79 & 2.54 & 0.81 & 0.05 & 7.12 \\
\hline C0006E-38X-2, 1-1.5 & 296.70 & 2.60 & 2.79 & 16.7 & 64.9 & 0.28 & 0.22 & 2.75 & 1.84 & 0.75 & 0.03 & 7.08 \\
\hline C0006E-39X-3, 71-72.5 & 309.37 & 2.66 & 2.90 & 16.7 & 64.5 & 0.26 & 0.21 & 2.73 & 2.00 & 0.78 & 0.04 & 7.20 \\
\hline C0006E-40X-3, 51-53 & 318.68 & 1.55 & 2.74 & 17.5 & 65.0 & 0.25 & 0.20 & 3.10 & 1.67 & 0.78 & 0.06 & 7.20 \\
\hline C0006E-40X-8, 60-61.5 & 323.02 & 2.71 & 2.68 & 16.8 & 65.2 & 0.26 & 0.38 & 2.54 & 2.45 & 0.71 & 0.04 & 6.25 \\
\hline C0006E-41X-3, 44-46 & 328.10 & 1.73 & 2.75 & 16.3 & 64.3 & 0.30 & 0.22 & 2.88 & 2.75 & 0.83 & 0.04 & 7.90 \\
\hline C0006E-45X-1, 37.5-39 & 363.21 & 2.75 & 3.02 & 16.7 & 62.7 & 0.31 & 0.26 & 2.74 & 2.92 & 0.83 & 0.07 & 7.71 \\
\hline C0006E- $45 X-3,81.5-83$ & 366.45 & 2.43 & 2.92 & 16.6 & 64.9 & 0.34 & 0.21 & 2.80 & 2.16 & 0.79 & 0.04 & 6.78 \\
\hline C0006E-45X-4, 0-1.5 & 366.67 & 2.61 & 2.94 & 17.0 & 63.8 & 0.30 & 0.25 & 2.80 & 2.40 & 0.77 & 0.06 & 6.99 \\
\hline C0006E-47X-5, 0-1.5 & 386.73 & 2.90 & 2.87 & 16.3 & 63.9 & 0.31 & 0.24 & 2.68 & 2.92 & 0.77 & 0.05 & 7.06 \\
\hline C0006F-1R-1, 130-132 & 396.31 & 2.00 & 2.83 & 16.8 & 65.0 & 0.24 & 0.16 & 2.94 & 1.57 & 0.82 & 0.05 & 7.49 \\
\hline C0006F-2R-3, 28-30 & 406.20 & 2.06 & 2.74 & 16.8 & 65.1 & 0.24 & 0.16 & 2.82 & 2.24 & 0.78 & 0.05 & 7.02 \\
\hline C0006F-4R-1, 86-88 & 424.37 & 2.46 & 2.71 & 16.8 & 65.0 & 0.25 & 0.16 & 3.03 & 1.78 & 0.82 & 0.03 & 7.04 \\
\hline C0006F-4R-2, 33-34.5 & 425.24 & 2.24 & 2.63 & 16.7 & 64.4 & 0.23 & 0.21 & 2.82 & 3.08 & 0.77 & 0.03 & 6.90 \\
\hline C0006F-5R-1, 117-118.5 & 434.18 & 2.39 & 2.65 & 17.2 & 65.4 & 0.25 & 0.18 & 2.84 & 1.80 & 0.76 & 0.03 & 6.54 \\
\hline
\end{tabular}

Notes: Results for silty clays containing $>48 \%$ and $<54 \%$ total clay minerals (by X-ray diffraction), Subunits IIB, IIC, and IID in Holes C0006E and C0006F. CSF = core depth below seafloor. 
Table T7. X-ray fluorescence data for three gravel clasts, interval 316-C0007C-17H-CC, 0-5 cm (159 mbsf). (See table notes.)

\begin{tabular}{|c|c|c|c|c|c|c|c|c|c|c|c|c|c|c|c|c|c|c|c|c|c|}
\hline \multirow[b]{3}{*}{ Clast } & \multirow{2}{*}{\multicolumn{11}{|c|}{ Major element by XRF (wt\%) }} & \multirow{2}{*}{\multicolumn{4}{|c|}{ Clay mineral by XRD (\%) }} & \multicolumn{4}{|c|}{ Calculated from XRF } & \multirow{2}{*}{\multicolumn{2}{|c|}{$\begin{array}{l}\text { Calculated } \\
\text { from XRD }\end{array}$}} \\
\hline & & & & & & & & & & & & & & & & & & & & & \\
\hline & $\mathrm{Na}_{2} \mathrm{O}$ & $\mathrm{MgO}$ & $\mathrm{Al}_{2} \mathrm{O}_{3}$ & $\mathrm{SiO}_{2}$ & $\mathrm{P}_{2} \mathrm{O}_{5}$ & $\mathrm{~s}$ & $\mathrm{~K}_{2} \mathrm{O}$ & $\mathrm{CaO}$ & $\mathrm{TiO}_{2}$ & $\mathrm{MnO}$ & $\mathrm{Fe}_{2} \mathrm{O}_{3}$ & Clay & Quartz & Plagioclase & Calcite & non-f & $A b$ & An & plagioclase & $\mathrm{Na}_{2} \mathrm{O}$ & $\mathrm{CaO}$ \\
\hline CKY1404600 & 1.84 & 0.83 & 8.32 & 83.8 & 0.25 & 0.17 & 1.81 & 0.26 & 0.23 & 0.02 & 2.48 & 15.4 & 56.4 & 28.2 & 0.0 & 35.8 & 76 & 24 & 5.2 & 2.5 & 1.3 \\
\hline CKY1422600 & 2.08 & 1.00 & 4.78 & 89.3 & 0.20 & 0.12 & 0.25 & 0.09 & 0.17 & 0.01 & 2.00 & 11.1 & 71.1 & 17.8 & 0.0 & 36.2 & 92 & 8 & 4.8 & 1.6 & 0.9 \\
\hline CKY1422500 & 2.37 & 1.33 & 15.40 & 70.4 & 0.27 & 0.40 & 3.35 & 1.60 & 0.59 & 0.04 & 4.29 & 18.1 & 47.3 & 34.6 & 0.0 & 34.1 & 40 & 60 & 10.0 & 3.1 & 1.7 \\
\hline
\end{tabular}

Notes: non-q, non- $\mathrm{f}=$ weight percent remaining in X-ray fluorescence (XRF) analysis after removal of X-ray diffraction (XRD)-determined quartz and XRF-limited plagioclase. Ab and An assume all $\mathrm{Na}$ and $\mathrm{Ca}$ assigned to plagioclase. 
Table T8. Astrochronological age estimates of nannofossil events used as biostratigraphic tie points, Expedition 316. (See table notes.) (Continued on next page.)

\begin{tabular}{|c|c|c|}
\hline Nannofossil event & Zone (base) & Age (Ma) \\
\hline X Gephyrocapsa spp. (>3.5 $\mu \mathrm{m})$-Emiliania huxleyi & & 0.063 \\
\hline FO Emiliania huxleyi & NN21 & 0.291 \\
\hline LO Pseudoemiliania lacunosa & NN20 & 0.436 \\
\hline LCO Reticulofenestra asanoi & & 0.9 \\
\hline RE Gephyrocapsa spp. ( $\geq 4 \mu \mathrm{m})$ & & 1.04 \\
\hline FCO Reticulofenestra asanoi & & $1.078^{*}$ \\
\hline LO Gephyrocapsa spp. (>5.5 $\mu \mathrm{m})$ & & 1.24 \\
\hline LO Helicosphaera sellii & & 1.34 \\
\hline FCO Gephyrocapsa spp. (>5.5 $\mu \mathrm{m})$ & & 1.46 \\
\hline FO Gephyrocapsa spp. (>5.5 $\mu \mathrm{m})$ & & $1.560-1.617^{*}$ \\
\hline LO Calcidiscus macintyrei $(\geq 11 \mu \mathrm{m})$ & & 1.6 \\
\hline FO Gephyrocapsa spp. (>3.5 $\mu \mathrm{m})$ & & 1.67 \\
\hline LO Discoaster brouweri & NN19 & 2.06 \\
\hline AB Discoaster triradiatus & & $2.135-2.216^{*}$ \\
\hline LO Discoaster pentaradiatus & NN18 & $2.393-2.512^{*}$ \\
\hline LO Discoaster surculus & NN17 & 2.52 \\
\hline LO Discoaster tamalis & & 2.87 \\
\hline LO Sphenolithus spp. & & 3.65 \\
\hline LO Reticulofenestra pseudoumbilicus (>7 $\mu \mathrm{m})$ & NN16 & 3.79 \\
\hline FCO Discoaster asymmetricus & NN15-NN14 & 4.13 \\
\hline LO Amaurolithus primus & & 4.5 \\
\hline LO Ceratolithus acutus & & 5.04 \\
\hline FO Ceratolithus rugosus & NN13 & 5.12 \\
\hline FO Ceratolithus acutus & & 5.32 \\
\hline LO Discoaster quinqueramus & NN12 & 5.59 \\
\hline LO Nicklithus amplificus & & $5.9^{*}$ \\
\hline PE Reticulofenestra pseudoumbilicus ( $>7 \mu \mathrm{m})$ & & $7.1^{*}$ \\
\hline FO Amaurolithus spp. = FO Amaurolithus primus & NN11b & $7.362-7.424^{*}$ \\
\hline FCO Discoaster surculus & & 7.88 \\
\hline LCO Minylitha convallis & & $7.78-8.3^{*}$ \\
\hline FO Discoaster berggrenii & NN11a & 8.52 \\
\hline PB Reticulofenestra pseudoumbilicus & NN10b & 8.785 \\
\hline FO Discoaster pentaradiatus & & 9.1 \\
\hline LO Catinaster coalitus & & 9.416 \\
\hline FO Minylitha convallis & & 9.416 \\
\hline LO Discoaster hamatus & NN10a & 9.56 \\
\hline LO Catinaster calyculus & & $9.687^{*}$ \\
\hline X Discoaster hamatus-D. neohamatus & & $9.762^{*}$ \\
\hline FO Discoaster neohamatus & & $9.867-10.521^{*}$ \\
\hline LCO Discoaster exilis & & 10.427 \\
\hline FO Discoaster hamatus & NN9 & 10.541 \\
\hline FO Discoaster calcaris & & 10.676 \\
\hline FO Discoaster bellus gr. & & 10.72 \\
\hline FO Discoaster brouweri & & $10.734-10.764^{*}$ \\
\hline FO Catinaster calyculus & & 10.785 \\
\hline FO Catinaster coalitus & NN8 & 10.886 \\
\hline LO Coccolithus miopelagicus & & $10.97-11.02^{*}$ \\
\hline LCO Discoaster kugleri & & 11.578 \\
\hline FCO Discoaster kugleri & NN7 & 11.863 \\
\hline LO Cyclicargolithus floridanus & & 12.037 \\
\hline LO Coronocyclus nitescens & & 12.254 \\
\hline LCO Calcidiscus premacintyrei & & 12.447 \\
\hline FCO Triquetrorhabdulus rugosus & & 12.671 \\
\hline LCO Cyclicargolithus floridanus & & 13.294 \\
\hline LO Sphenolithus heteromorphus & NN6 & 13.532 \\
\hline LO Helicosphaera ampliaperta & NN5 & $14.914^{*}$ \\
\hline AE Discoaster deflandrei & & $15.663^{*}$ \\
\hline FO Discoaster signus & & $15.702^{*}$ \\
\hline FCO Sphenolithus heteromorphus & & $17.721^{*}$ \\
\hline LCO Sphenolithus belemnos & NN4 & $17.973^{*}$ \\
\hline LO Triquetrorhabdulus carinatus & & $18.315^{*}$ \\
\hline FO Sphenolithus belemnos & NN3 & $18.921^{*}$ \\
\hline FO Helicosphaera ampliaperta & & $20.393^{*}$ \\
\hline X Helicosphaera euphratis-Helicosphaera carteri & & $20.894^{\star}$ \\
\hline FCO Helicosphaera carteri & & $21.985^{*}$ \\
\hline LCO Triquetrorhabdulus carinatus & & $22.092^{*}$ \\
\hline FO Sphenolithus disbelemnos & & $22.760^{*}$ \\
\hline FO Discoaster druggi & NN2 & $22.824^{*}$ \\
\hline
\end{tabular}


Table T8 (continued).

\begin{tabular}{lll}
\hline \multicolumn{1}{c}{ Nannofossil event } & Zone (base) & Age (Ma) \\
\hline LO Sphenolithus delphix & & $23.065^{*}$ \\
FO Sphenolithus delphix & & $23.328^{*}$ \\
LO Sphenolithus ciperoensis & NN1 & $24.242^{*}$ \\
\hline
\end{tabular}

Notes: * ${ }^{*}$ datum based on Atlantic or Mediterranean records. Age estimates based on Raffi et al. (2006). $X=$ crossover in abundance, FO $=$ first occurrence, $L O=$ last occurrence, $L C O=$ last consistent occurrence, $R E=$ reentrance, $F C O=$ first consistent occurrence, $A B=a c m e$ beginning, $\mathrm{PE}=$ paracme end $\mathrm{PB}=$ paracme beginning, $\mathrm{AE}=$ acme end. 
Table T9. Radiolarian datum events, Expedition 316. (See table note.)

\begin{tabular}{|c|c|c|}
\hline Event & Zone & Age (Ma) \\
\hline LO Axoprunum acquilonium & & 0.4 \\
\hline LO Stylatractus universus & Botryostrobus aquilonaris & 0.4 \\
\hline LO Anthocyrtella (?) callopisma & & 0.6 \\
\hline LO Lamprocyrtis neoheteroporos & & 0.85 \\
\hline FO Lychnocanoma nipponica sakaii & & 0.95 \\
\hline LO Eucyrtidium matuyamai & Stylatractus universus & 1.05 \\
\hline LO Sphaeropyle robusta & & 1.46 \\
\hline FO Eucyrtidium matuyamai & Eucyrtidium matuyamai & 1.8 \\
\hline LO Lamprocyrtis heteroporos & & 1.8 \\
\hline LCO Cycladophora sakaii & & 2.3 \\
\hline FO Botryostrobus aqullonaris & & 2.65 \\
\hline FO Ceratospyris borealis & & 2.65 \\
\hline FCO Cycladophora davisiana & & 2.65 \\
\hline LO Thecosphaera akitaensis & & 2.65 \\
\hline LO Stichocorys delmontensis & & 2.75 \\
\hline LO Stichocorys peregrina & & 2.75 \\
\hline ET Didymocyrtis tetrathalamus tetrathalamus & & 3 \\
\hline RI Spongosphaera resurgens osculosa & & 3.15 \\
\hline LO Ommatartus sp. & & 3.2 \\
\hline LO Dictyophimus bullatus & Cycladophora sakaii & 3.4 \\
\hline LO Phormostichoartus fistula & & 4.1 \\
\hline ET Didymocyrtis avita & & 4.2 \\
\hline FO Dictyophimus bullatus & Dictyophimus bullatus & 4.2 \\
\hline LO Stichocorys spp. group & & 4.2 \\
\hline FO Thecosphaera akitaensis & & 4.3 \\
\hline LO Dictyophimus bullatus & & 4.3 \\
\hline LO Didymocyrtis penultima & & 4.4 \\
\hline FO Dictyophimus bullatus & & 4.5 \\
\hline RD Siphocampe ex. gr. arachnea & & 4.5 \\
\hline LCO Stichocorys spp. group & & 4.6 \\
\hline RI Siphocampe ex. gr. arachnea & & 4.7 \\
\hline LCO Lipmanella japonica & & 4.7 \\
\hline RD Arachnocorallium spp. group & & 4.75 \\
\hline LCO Lipmanella redondoensis & & 5.06 \\
\hline FCO Thecosphaera pseudojaponica & & 5.1 \\
\hline LO Ommatartus sp. & & 5.16 \\
\hline FO Lamprocyrtis heteroporos & & 5.26 \\
\hline FO Spongurus pylomaticus & Spongurus pylomaticus & 5.26 \\
\hline RD Lithelius barbatus & & 5.26 \\
\hline RI Arachnocorallium spp. group & & 5.26 \\
\hline LO Dictyophimus splendens & & 5.63 \\
\hline LO Lychnocanoma parallelipes & Axoprunum acquilonium & 6.08 \\
\hline FO Sphaeropyle langii & & 6.1 \\
\hline LO Stichocorys delmontensis & & 6.16 \\
\hline FCO Thecosphaera japonica & & 6.3 \\
\hline FO Ommatartus sp. & & 6.6 \\
\hline LO Lychnocanoma nipponica nipponica & & 6.62 \\
\hline FO Axoprunum acquilonium & Lithelius barbatus & 7.193 \\
\hline RI Lithelius barbatus & & 7.193 \\
\hline LO Cycladophora cabriloensis & & 7.193 \\
\hline LO Cycladophora nakasekoi & & 7.193 \\
\hline FO Lychnocanoma parallelipes & & 7.2 \\
\hline RI Stichocorys peregina & & 7.2 \\
\hline
\end{tabular}

Note: $\mathrm{LO}=$ last occurrence, $\mathrm{FO}=$ first occurrence, $\mathrm{LCO}=$ last consistent occurrence, $\mathrm{FCO}=$ first consistent occurrence, $\mathrm{ET}=$ evolutionary transition, $\mathrm{RI}=$ rapid increase, $\mathrm{RD}=$ rapid decrease. 
Table T10. Ages used for the geomagnetic polarity timescale, Expedition 316. (See table note.)

\begin{tabular}{crll}
\hline \multicolumn{2}{c}{ Age } & (Ma) & \\
\cline { 1 - 2 } Top & Bottom & Chron \\
\cline { 1 - 3 } 0.000 & 0.781 & C1n \\
0.988 & 1.072 & C1r.1n \\
1.173 & 1.185 & C1r.2n \\
1.778 & 1.945 & C2n \\
2.581 & 3.032 & C2An.1n \\
3.116 & 3.207 & C2An.2n \\
3.330 & 3.596 & C2An.3n \\
4.187 & 4.300 & C3n.1n \\
4.493 & 4.631 & C3n.2n \\
4.799 & 4.896 & C3n.3n \\
4.997 & 5.235 & C3n.4n \\
6.033 & 6.252 & C3An.1n \\
6.436 & 6.733 & C3An.2n \\
7.140 & 7.212 & C3Bn \\
7.251 & 7.285 & C3Br.1n \\
7.454 & 7.489 & C3Br.2n \\
7.528 & 7.642 & C4n.1n \\
7.695 & 8.108 & C4n.2n \\
8.254 & 8.300 & C4r.1n \\
8.769 & 9.098 & C4An \\
9.321 & 9.409 & C4Ar.1n \\
9.656 & 9.717 & C4Ar.2n \\
9.779 & 9.934 & C5n.1n \\
9.987 & 11.040 & C5n.2n \\
11.118 & 11.154 & C5r.1n \\
11.554 & 11.614 & C5r.2n \\
12.041 & 12.116 & C5An.1n \\
12.207 & 12.415 & C5An.2n \\
12.730 & 12.765 & C5Ar.1n \\
12.820 & 12.878 & C5Ar.2n \\
13.015 & 13.183 & C5AAn \\
13.252 & 13.466 & C5ABn \\
13.734 & 14.095 & C5ACn \\
14.194 & 14.581 & C5ADn \\
14.784 & 14.877 & C5Bn.1n \\
15.032 & 15.160 & C5Bn.2n \\
15.974 & 16.268 & C5Cn.1n \\
16.303 & 16.472 & C5Cn.2n \\
16.543 & 16.721 & C5Cn.3n \\
17.235 & 17.533 & C5Dn \\
18.056 & 18.524 & C5En \\
18.748 & 19.722 & C6n \\
20.040 & 20.213 & C6An.1n \\
20.439 & 20.709 & C6An.2n
\end{tabular}

\begin{tabular}{|c|c|c|}
\hline \multicolumn{2}{|c|}{ Age $(\mathrm{Ma})$} & \multirow[b]{2}{*}{ Chron } \\
\hline Top & Bottom & \\
\hline 21.083 & 21.159 & C6AAn \\
\hline 21.659 & 21.688 & C6AAr.2n \\
\hline 21.767 & 21.936 & C6Bn.1n \\
\hline 21.992 & 22.268 & C6Bn.2n \\
\hline 22.564 & 22.758 & C6Cn.1n \\
\hline 22.902 & 23.030 & C6Cn.2n \\
\hline 23.249 & 23.375 & C6Cn.3n \\
\hline 24.044 & 24.102 & C7n.1n \\
\hline 24.146 & 24.556 & C7n.2n \\
\hline 24.915 & 25.091 & C7An \\
\hline 25.295 & 25.444 & $C 8 n .1 n$ \\
\hline 25.492 & 26.154 & $C 8 n \cdot 2 n$ \\
\hline 26.714 & 27.826 & C9n \\
\hline 28.186 & 28.450 & C10n.1n \\
\hline 28.525 & 28.715 & C10n.2n \\
\hline 29.451 & 29.740 & $\mathrm{C} 11 \mathrm{n} .1 \mathrm{n}$ \\
\hline 29.853 & 30.217 & $C 11 n \cdot 2 n$ \\
\hline 30.627 & 31.116 & $\mathrm{C} 12 \mathrm{n}$ \\
\hline 33.266 & 33.738 & $C 13 n$ \\
\hline 34.782 & 35.043 & $C 15 n$ \\
\hline 35.404 & 35.567 & $C 16 n .1 n$ \\
\hline 35.707 & 36.276 & $\mathrm{C} 16 n \cdot 2 \mathrm{n}$ \\
\hline 36.512 & 37.235 & $C 17 n .1 n$ \\
\hline 37.345 & 37.549 & $C 17 n \cdot 2 n$ \\
\hline 37.610 & 37.771 & $C 17 n \cdot 3 n$ \\
\hline 38.032 & 38.975 & $C 18 n .1 n$ \\
\hline 39.041 & 39.464 & $\mathrm{C} 18 \mathrm{n} .2 \mathrm{n}$ \\
\hline 40.439 & 40.671 & C19n \\
\hline 41.590 & 42.774 & C20n \\
\hline 45.346 & 47.235 & $C 21 n$ \\
\hline 48.599 & 49.427 & $C 22 n$ \\
\hline 50.730 & 50.932 & $C 23 n .1 n$ \\
\hline 51.057 & 51.901 & $C 23 n .2 n$ \\
\hline 52.648 & 53.004 & $C 24 n .1 n$ \\
\hline 53.116 & 53.167 & $C 24 n .2 n$ \\
\hline 53.286 & 53.808 & $C 24 n .3 n$ \\
\hline 56.665 & 57.180 & C25n \\
\hline 58.379 & 58.737 & $C 26 n$ \\
\hline 61.650 & 61.983 & $C 27 n$ \\
\hline 63.104 & 64.128 & $C 28 n$ \\
\hline 64.432 & 65.118 & $C 29 n$ \\
\hline
\end{tabular}

Note: Data from Gradstein et al. (2004) (see also Fig. F25). 
Table T11. Shipboard and shore-based chemical analyses, Expedition 316. (See table notes.)

\begin{tabular}{|c|c|c|c|c|c|c|c|c|c|c|c|c|c|c|c|c|}
\hline \multirow[t]{2}{*}{ Sample code: } & IWIC & IWICP & IWSO4 & IWOD & IWSCL & IWHE & IWB & IWNR & IWTT1 & IWSH & IWLC & IWGW & IWHT & IWTT2 & \multicolumn{2}{|l|}{ IWVH } \\
\hline & \multicolumn{9}{|c|}{ Shipboard } & \multirow[b]{2}{*}{$\begin{array}{c}\text { REE, } \mathrm{Cd} \text {, } \\
\mathrm{Y}\end{array}$} & \multirow[b]{2}{*}{$\begin{array}{c}\mathrm{Cu}, \mathrm{Zn}, \mathrm{Co}, \\
\mathrm{Cr}, \mathrm{Pb}, \mathrm{Al}\end{array}$} & \multirow[b]{2}{*}{ U series } & \multirow[b]{2}{*}{$\begin{array}{l}I \text { and } \\
\text { isotopes }\end{array}$} & \multirow[b]{2}{*}{$\begin{array}{l}\text { DOC } \\
\text { and isotopes }\end{array}$} & \multirow[b]{2}{*}{ VFA } & \\
\hline $\begin{array}{l}\text { Type of } \\
\text { analysis: }\end{array}$ & $\begin{array}{c}\text { Alk, } \mathrm{pH}, \\
\mathrm{Cl}, \mathrm{IC}\end{array}$ & $\begin{array}{l}\text { ICP-AES/MS, } \\
\text { phosphate }\end{array}$ & Sulfate & $\delta^{18} \mathrm{O}, \delta \mathrm{D}$ & $\begin{array}{l}\mathrm{Sr}, \mathrm{Li}, \mathrm{Cl} \\
\text { isotopes }\end{array}$ & $\begin{array}{c}\mathrm{He}, \mathrm{Ne} \\
\mathrm{Ar}, \mathrm{Kr} \\
\text { isotopes }\end{array}$ & $\begin{array}{c}\text { B } \\
\text { isotopes }\end{array}$ & $\begin{array}{c}S \\
\text { isotopes }\end{array}$ & $\begin{array}{l}\text { DIC and } \\
\text { isotopes }\end{array}$ & & & & & & & \\
\hline $\begin{array}{l}\text { Shore-based } \\
\text { investigator: }\end{array}$ & - & - & - & Tomaru & Solomon & Solomon* & Wheat & Riedinger & Toki & Hulme & Claesson & Wheat & Tomaru & Toki & Heuer & \\
\hline Container: & $\begin{array}{l}4 \mathrm{~mL} \\
\mathrm{HDPE}\end{array}$ & $\begin{array}{l}4 \mathrm{~mL} \\
\text { HDPE }\end{array}$ & $\begin{array}{c}0-5 \mathrm{~mL} \\
\mathrm{HDPE}\end{array}$ & $\begin{array}{l}2 \mathrm{~mL} \\
\mathrm{HDPE}\end{array}$ & $\begin{array}{l}3 \mathrm{~mL} \\
\text { HDPE }\end{array}$ & $\begin{array}{c}2 \mathrm{~mL} \\
\text { Cu tubing }\end{array}$ & $\begin{array}{l}3 \mathrm{~mL} \\
\mathrm{HDPE}\end{array}$ & $\begin{array}{l}2 \mathrm{~mL} \\
\mathrm{HDPE}\end{array}$ & $\begin{array}{l}2 \mathrm{~mL} \\
\text { glass }\end{array}$ & $\begin{array}{l}\text { 5-8 mL } \\
\mathrm{HDPE}^{\dagger}\end{array}$ & $\begin{array}{c}1-3 \mathrm{~mL} \\
\text { HDPE }\end{array}$ & $\begin{array}{c}8 \mathrm{~mL} \\
\mathrm{HDPE}^{\dagger}\end{array}$ & $\begin{array}{c}2-10 \mathrm{~mL} \\
\text { HDPE }^{\ddagger}\end{array}$ & $3 \mathrm{~mL}^{* *}$ & $2.4 \mathrm{~mL}^{* *}$ & \\
\hline Preservative: & & $\begin{array}{c}16 \mu \mathrm{L} \\
6 \mathrm{~N} \mathrm{HCl}\end{array}$ & $\begin{array}{c}20 \mu \mathrm{L} \\
\mathrm{Cd}\left(\mathrm{NO}_{3}\right)_{2}\end{array}$ & & & & & & $\mathrm{HgCl}_{2}$ & & & & & Freeze & Freeze & Total \\
\hline Volume $(\mathrm{mL})$ : & & & & & & & & & & & & & & & & \\
\hline$>55$ & 4 & 4 & 0.1 & 2 & 3 & 2 & 3 & 2 & 2 & 8 & 3 & 8 & 10 & 3 & 2.4 & 56.5 \\
\hline 50 & 4 & 4 & 0.1 & 2 & 3 & 2 & 3 & 2 & 2 & 8 & 3 & 8 & 6 & 3 & 2.4 & 52.5 \\
\hline 45 & 4 & 4 & 0.1 & 2 & 3 & 2 & 3 & 2 & 2 & 7 & 3 & 8 & 2 & 3 & 2.4 & 47.5 \\
\hline 40 & 4 & 3 & 0.1 & 2 & 3 & 2 & 3 & 2 & 2 & 5 & 2 & 8 & 2 & 3 & 1.5 & 42.6 \\
\hline 35 & 4 & 3 & 0.1 & 2 & 3 & 2 & 3 & 2 & 2 & 5 & 2 & 8 & 2 & 1 & 1 & 40.1 \\
\hline 30 & 4 & 3 & 0.1 & 2 & 3 & 2 & 3 & 2 & 2 & 5 & 2 & 0 & 2 & 1 & 1 & 32.1 \\
\hline 25 & 4 & 3 & 0.1 & 2 & 3 & 2 & 2 & 0 & 2 & 5 & 1 & 0 & 2 & 0 & 1 & 27.1 \\
\hline 20 & 4 & 2 & 0.1 & 2 & 3 & 2 & 2 & 0 & 2 & 5 & 1 & 0 & 0 & 0 & 0 & 23.1 \\
\hline 15 & 4 & 2 & 0.1 & 2 & 3 & 2 & 3 & 0 & 0 & 0 & 1 & 0 & 0 & 0 & 0 & 17.1 \\
\hline 5 & 1 & 2 & 0.1 & 1 & 2 & 0 & 1 & 0 & 0 & 0 & 0 & 0 & 0 & 0 & 0 & 7.1 \\
\hline
\end{tabular}

Notes: ${ }^{*}=$ noble gas sampling only for 5 samples per hole close to the fault zone to be done by $\mathrm{E}$. Solomon, $\dagger=$ medium, $\ddagger=$ medium to large, $* *=$ use $2 \times 1.5 \mathrm{~mL}$ amber glass vials. Red and blue alternated between cores at the specified volume of pore fluid recovery. IC = ion chromatography, ICP-AES/MS = inductively coupled plasma-atomic emission spectrometer/mass spectrometer. DIC = dissolved inorganic carbon, REE = rare earth elements, I = iodine concentration, DOC = dissolved organic carbon concentration, VFA = volatile fatty acids. HDPE = highdensity polyethylene. 
Table T12. Pore fluid squeeze cake distribution for shore-based analyses, Expedition 316. (See table notes.)

\begin{tabular}{|c|c|c|c|c|}
\hline Investigator & $\begin{array}{c}\text { Sample } \\
\text { code }\end{array}$ & $\begin{array}{l}\text { Volume } \\
\left(\mathrm{cm}^{3}\right)\end{array}$ & Type of analyses & Comments \\
\hline \multicolumn{5}{|l|}{ Squeeze cake 1 : } \\
\hline Solomon & IWSES & 10 & $\delta^{37} \mathrm{Cl}, \delta^{7} \mathrm{Li},{ }^{87} \mathrm{Sr} /{ }^{86} \mathrm{Sr}, \mathrm{Ba}, \mathrm{Sr}, \mathrm{Cl}$ & \\
\hline Claesson & IWSLC & 10 & Minor and trace elements & \\
\hline Riedinger & IWSNR & 10 & Sulfur and iron & \\
\hline Destrigneville & IWSD & 10 & Mineralogy, clay mineralogy & \\
\hline \multicolumn{5}{|l|}{ Squeeze cake 2 : } \\
\hline Henry & IWSPH & 20 & Water distribution & \\
\hline Toki & IWSTT & 20 & Carbonate & Keep sample frozen \\
\hline Heuer & IWSVH & 10 & VFAs and amino acids & Keep sample frozen \\
\hline Tomaru & IWSHT & 10 & $129\left|/^{127}\right|$ & \\
\hline
\end{tabular}

Notes: For squeeze cake 2, IWSPH and IWSHT were alternated between cores. If there were more than two squeeze cakes, $20 \mathrm{~cm}^{3}$ of sample was saved as archive, then sampling continued from the top of the list. VFA = volatile fatty acids.

Table T13. Calibration constants used for TeKa full- and half-space thermal conductivity measurements. (See table notes.)

\begin{tabular}{lcc}
\hline Constant & Full space & Half space \\
\hline A & -0.057 & 0.305 \\
B & 1.013 & 0.263 \\
C & - & 0.323 \\
\hline
\end{tabular}

Notes: Calibration equations for constants took the form of $y=a+b x$ for the full-space measurements and $y=a+b x+c x^{2}$ for the half-space measurements. Needle used for full-space measurements was V10305. Needle used for half-space measurements was H10304. $-=$ not applicable. 